Nevada

Environmental

Restoration

Project

Streamlined Approach for

Environmental Restoration (SAFER)

Plan for Corrective Action Unit 553:

Areas 19, 20 Mud Pits and Cellars

Nevada Test Site, Nevada

Controlled Copy No.:

Revision No.: 0

November 2006

Approved for public release; further dissemination unlimited.

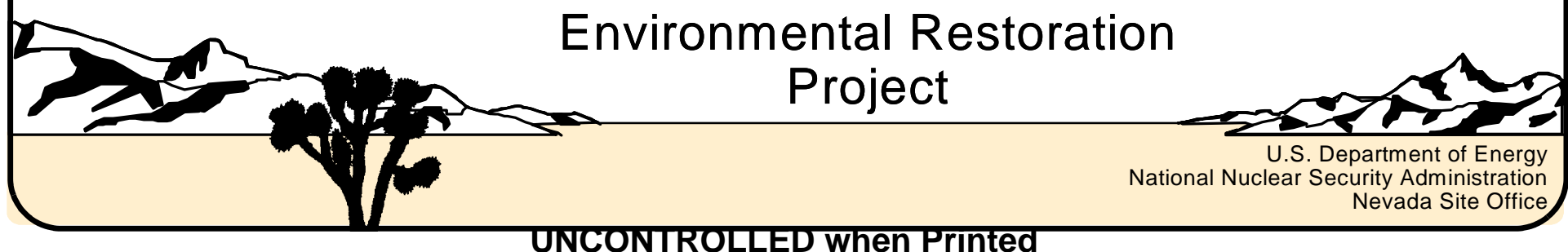


Available for public sale, in paper, from:

U.S. Department of Commerce

National Technical Information Service

5285 Port Royal Road

Springfield, VA 22161

Phone: 800.553 .6847

Fax: 703.605.6900

Email: orders@ntis.gov

Online ordering: http://www.ntis.gov/ordering.htm

Available electronically at http://www.osti.gov/bridge

Available for a processing fee to U.S. Department of Energy and its contractors, in paper, from:

\section{U.S. Department of Energy}

Office of Scientific and Technical Information

P.O. Box 62

Oak Ridge, TN 37831-0062

Phone: 865.576.8401

Fax: 865.576.5728

Email: reports@adonis.osti.gov

Reference herein to any specific commercial product, process, or service by trade name, trademark, manufacturer, or otherwise, does not necessarily constitute or imply its endorsement, recommendation, or favoring by the United States Government or any agency thereof or its contractors or subcontractors. 


\title{
STREAMLINED APPROACH FOR ENVIRONMENTAL RESTORATION (SAFER) PLAN FOR CORRECTIVE ACTION UNIT 553: AREAS 19, 20 MUD PITS AND CELLARS NEVADA TEST SITE, NEVADA
}

\author{
U.S. Department of Energy \\ National Nuclear Security Administration \\ Nevada Site Office \\ Las Vegas, Nevada
}

Controlled Copy No.:

Revision No.: 0

November 2006

Approved for public release; further dissemination unlimited. 
STREAMLINED APPROACH FOR ENVIRONMENTAL RESTORATION (SAFER) PLAN FOR CORRECTIVE ACTION UNIT 553:

AREAS 19, 20 MUD PITS AND CELLARS NEVADA TEST SITE, NEVADA

Approved by: APPROVED SIGNATURE

Date: $11 / 16 / 2006$

Kevin Cabble

Federal Sub-Project Director

Industrial Sites Sub-Project

Approved by: APPROVED SIGNATURE

John B. Jones

Acting Federal Project Director

Environmental Restoration Project 


\section{Table of Contents}

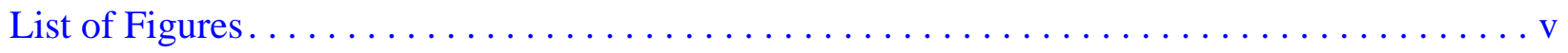

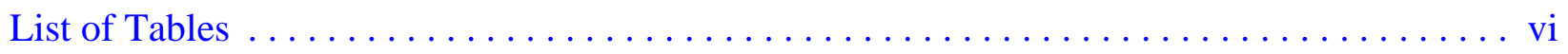

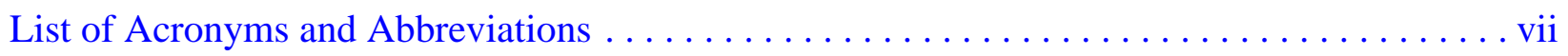

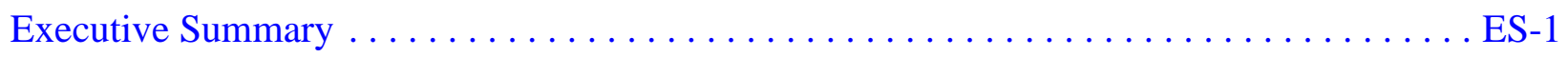

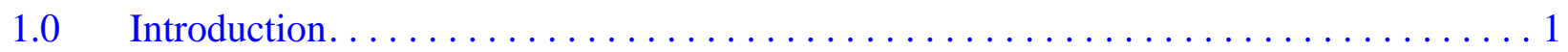

$1.1 \quad$ SAFER Process Description. ............................ 3

$1.2 \quad$ Summary of Corrective Actions and Closures . . . . . . . . . . . . . . . 3

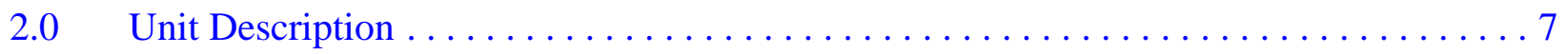

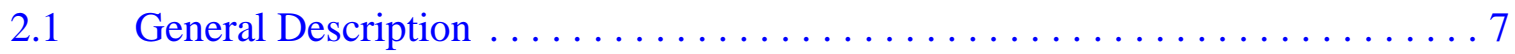

2.1.1 Mud Pit Process and Contaminant Release ................ 7

2.2 CAS 19-99-01, Mud Spill. ......................... 8

2.2 .1 Description and Location........................ 8

2.2.2 History and Process Knowledge $\ldots \ldots \ldots \ldots \ldots \ldots \ldots \ldots \ldots$

2.2.3 Available Characterization Information . . . . . . . . . . . . 10

$2.3 \quad$ CAS 19-99-11, Mud Spill. ............................. 10

2.3.1 Description and Location........................... 10

2.3.2 History and Process Knowledge $\ldots \ldots \ldots \ldots \ldots \ldots \ldots \ldots \ldots$

2.3.3 Available Characterization Information ................ 12

2.4 CAS 20-09-09, Mud Spill............................... 12

2.4.1 Description and Location.......................... 12

2.4.2 History and Process Knowledge $\ldots \ldots \ldots \ldots \ldots \ldots \ldots \ldots \ldots \ldots \ldots \ldots$

2.4.3 Available Characterization Information $\ldots \ldots \ldots \ldots \ldots \ldots \ldots 12$

$2.5 \quad$ CAS 20-99-03, Mud Spill. .............................. 14

2.5 .1 Description and Location............................ 14

2.5.2 History and Process Knowledge .................... 14

2.5.3 Available Characterization Information ................ 14

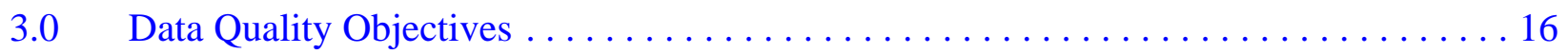

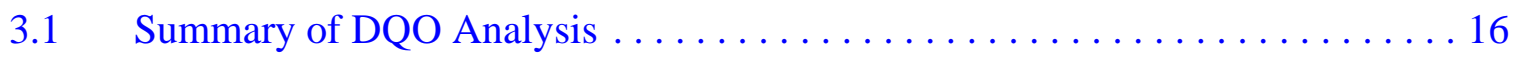

3.2 Results of the DQO Analysis . ........................... 20

3.2.1 Action Level Determination and Basis ................. 20

3.2.1.1 Chemical PALs ....................... 22

3.2.1.2 Total Petroleum Hydrocarbon PALs . . . . . . . . . . 22

3.2.1.3 Radionuclide PALs . . . . . . . . . . . . . . . . 22

3.2.2 Hypothesis Test ............................ 23

3.2 .3 Statistical Model ............................. 23

3.2.4 Design Description/Option $\ldots \ldots \ldots \ldots \ldots \ldots \ldots \ldots \ldots \ldots \ldots$ 


\section{Table of Contents (Continued)}
3.2 .5
3.2.4.1 Judgmental Sampling .23
Conceptual Site Model and Drawing. ................ 24

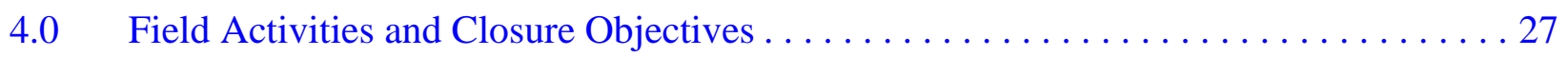

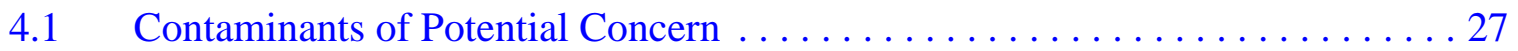

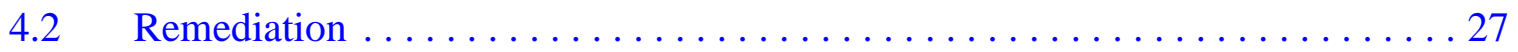

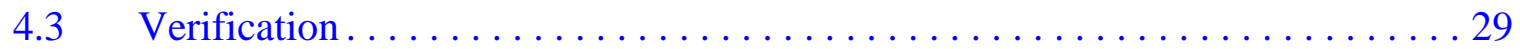

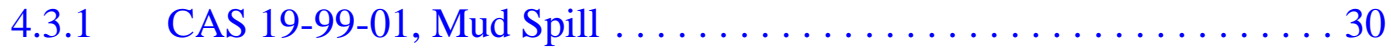

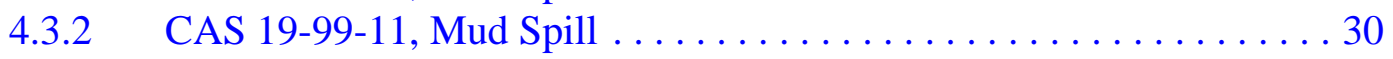

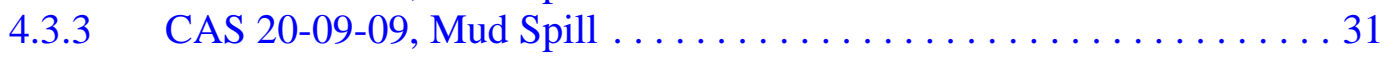

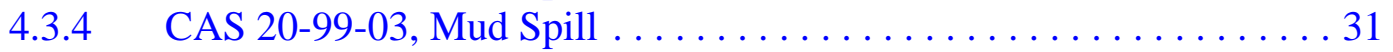

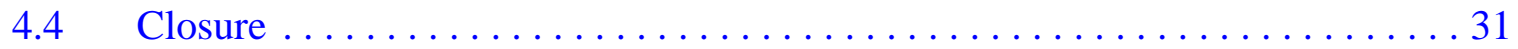

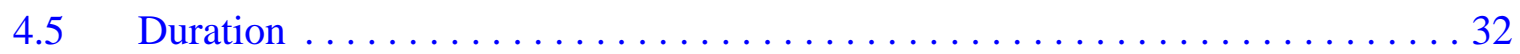

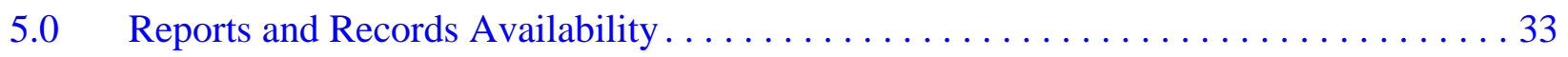

6.0 Investigation/Remediation Waste Management . . . . . . . . . . . . . . 34

6.1 Waste Minimization . . . . . . . . . . . . . . . . . . . . 34

6.2 Potential Waste Streams . . . . . . . . . . . . . . . . . . . . . . 35

6.2.1 Sanitary Waste. . . . . . . . . . . . . . . . . . . . 35

6.2.2 Low-Level Radioactive Waste. . . . . . . . . . . . . . . . . . . . . 37

6.2.3 Hazardous Waste . . . . . . . . . . . . . . . . . . . . . . . . . . . 37

6.2 .4 Hydrocarbon Waste . . . . . . . . . . . . . . . . . . 38

6.2 .5 Mixed Low-Level Waste . . . . . . . . . . . . . . . . . . . 38

6.2.6 Polychlorinated Biphenyls. . . . . . . . . . . . . . . . . 39

6.3 Management of Specific Waste Streams . . . . . . . . . . . . . . . . 39

6.3.1 Personal Protective Equipment . . . . . . . . . . . . . . . 39

6.3.2 Management of Decontamination Rinsate. . . . . . . . . . . . . 40

6.3.3 Management of Soil/Bentonite . . . . . . . . . . . . . . 40

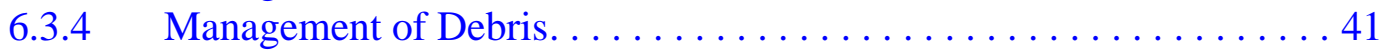

6.3.5 Field-Screening Waste. ................... 41

7.0 Quality Assurance/Quality Control . . . . . . . . . . . . . . . . 43

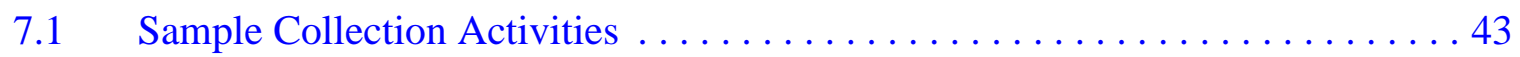

7.2 Applicable Laboratory/Analytical Data Quality Indicators . . . . . . . . . . 43

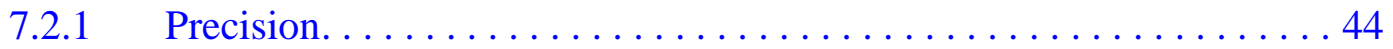

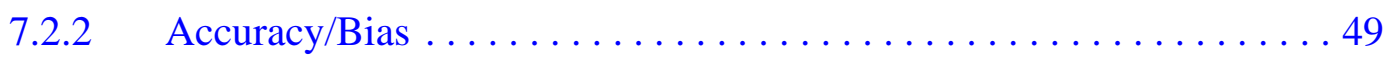

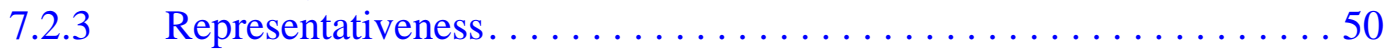

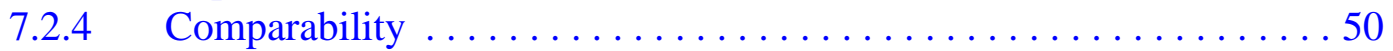

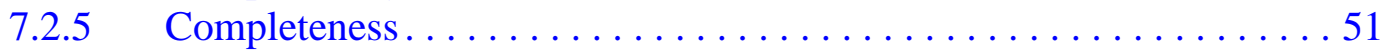

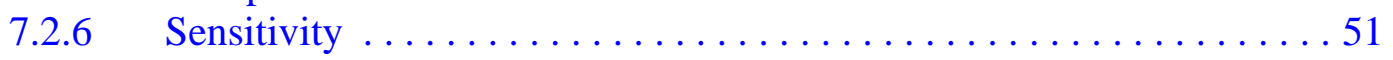




\section{Table of Contents (Continued)}

$8.0 \quad$ References........................................... 52

\section{Appendix A - Project Organization}

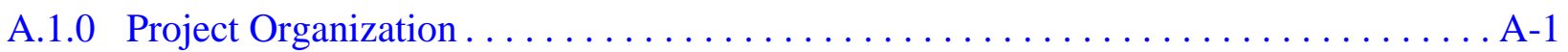

\section{Appendix B - Data Quality Objectives Process}

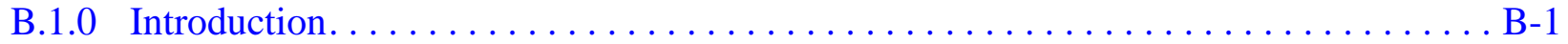

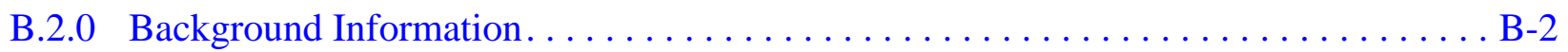

B.2.1 CAS 19-99-01, Mud Spill. . . . . . . . . . . . . . . . . . . B-2

B.2.2 CAS 19-99-11, Mud Spill............................ B-4

B.2.3 CAS 20-09-09, Mud Spill........................... B-5

B.2.4 CAS 20-99-03, Mud Spill. . . . . . . . . . . . . . . . . . . . B-6

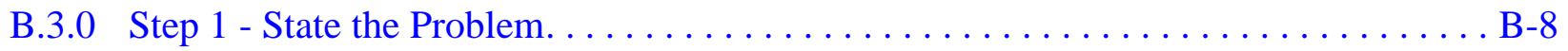

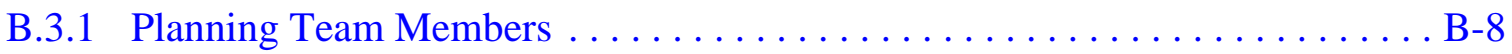

B.3.2 Conceptual Site Model . . . . . . . . . . . . . . . . . . . . . . .

B.3.2.1 Contaminant Release ........................ B-10

B.3.2.2 Potential Contaminants ........................ B-11

B.3.2.3 Contaminant Characteristics ................... B-13

B.3.2.4 Site Characteristics ......................... B-14

B.3.2.4.1 Groundwater ....................... B-15

B.3.2.4.2 Migration Pathways and Transport Mechanisms .... . B-15

B.3.2.5 Exposure Scenarios ........................ B-16

B.4.0 Step 2 - Identify the Goal of the Study $\ldots \ldots \ldots \ldots \ldots \ldots \ldots \ldots \ldots \ldots \ldots \ldots \ldots \ldots \ldots \ldots$

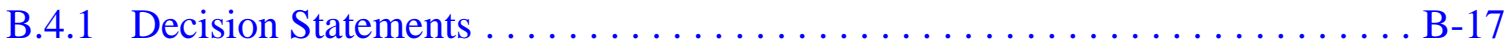

B.4.2 Alternative Actions to the Decisions .................... B-17

B.4.2.1 Alternative Actions to Decision I . . . . . . . . . . . . B-18

B.4.2.2 Alternative Actions to Decision II . . . . . . . . . . . . . B-18

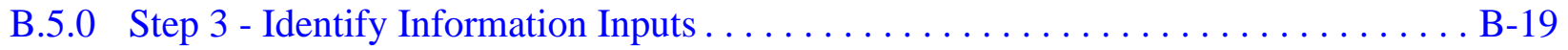

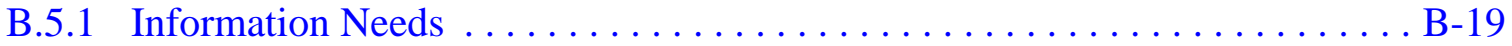

B.5.2 Sources of Information ............................

B.5.2.1 Sample Locations....................... B-19

B.5.2.1.1 Judgmental Approach for Sample Location

Selection ........................... B-20

B.5.2.2 Analytical Methods ........................ B-22

B.6.0 Step 4 - Define the Boundaries of the Study $\ldots \ldots \ldots \ldots \ldots \ldots \ldots \ldots \ldots$ B-24 


\section{Table of Contents (Continued)}

B.6.1 Target Populations of Interest. . . . . . . . . . . . . . . . . . B-24

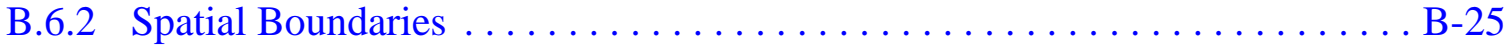

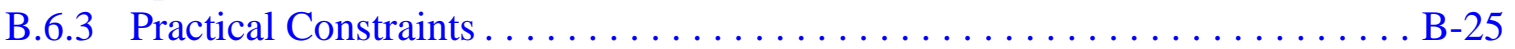

B.6.4 Define the Scale of Decision-Making. . . . . . . . . . . . . B-26

B.7.0 Step 5 - Develop the Analytical Approach . . . . . . . . . . . . . . . . . . B-27

B.7.1 Population Parameters $\ldots \ldots \ldots \ldots \ldots \ldots \ldots \ldots \ldots \ldots \ldots \ldots \ldots \ldots \ldots \ldots \ldots \ldots \ldots$

B.7.2 Action Levels . . . . . . . . . . . . . . . . . . . . . . . . . B-27

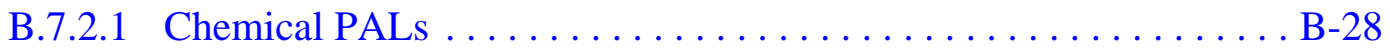

B.7.2.2 Total Petroleum Hydrocarbon PALs . . . . . . . . . . . . . . . B-28

B.7.2.3 Radionuclide PALs . . . . . . . . . . . . . . . . . . . . . . . . B-28

B.7.3 Measurement and Analysis Sensitivity. . . . . . . . . . . . . . . . B-29

B.7.4 Decision Rules . . . . . . . . . . . . . . . . . . . B-29

B.8.0 Step 6 - Specify Performance or Acceptance Criteria . . . . . . . . . . . . . . . B-31

B.8.1 Decision Hypotheses. . . . . . . . . . . . . . . . . . . . . . B-31

B.8.2 False Negative Decision Error $\ldots \ldots \ldots \ldots \ldots \ldots \ldots \ldots \ldots \ldots \ldots \ldots \ldots \ldots \ldots \ldots \ldots \ldots \ldots \ldots$

B.8.2.1 False Negative Decision Error for Judgmental Sampling . . . . . . . . B-32

B.8.3 False Positive Decision Error . . . . . . . . . . . . . . B-33

B.9.0 Step 7 - Develop the Plan for Obtaining Data . . . . . . . . . . . . . . . B-35

B.9.1 Mud Spill Sampling Designs . . . . . . . . . . . . . . . . . B-36

B.9.1.1 CAS 19-99-01, Mud Spill . . . . . . . . . . . . . . . . B-36

B.9.1.2 CAS 19-99-11, Mud Spill . . . . . . . . . . . . . . . . . B-37

B.9.1.3 CAS 20-09-09, Mud Spill . . . . . . . . . . . . . . . B-37

B.9.1.4 CAS 20-99-03, Mud Spill . . . . . . . . . . . . . . . . B-37

B.10.0 References. . . . . . . . . . . . . . . . . . . . . . . . . . . .

\section{Appendix C - Nevada Division of Environmental Protection Comments}

C.1.0 Nevada Division of Environmental Protection Comments. . . . . . . . . . . . . . . C-1 


\section{List of Figures}

Number

Title

Page

1-1 Nevada Test Site Map with CAU 553 CAS Locations . . . . . . . . . . . . . . 2

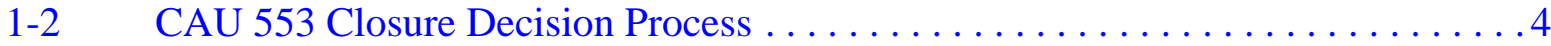

2-1 Corrective Action Site 19-99-01, Mud Spill . . . . . . . . . . . . . . 9

2-2 Corrective Action Site 19-99-11, Mud Spill . . . . . . . . . . . . . . 11

2-3 Corrective Action Site 20-09-09, Mud Spill . . . . . . . . . . . . . . 13

2-4 Corrective Action Site 20-99-03, Mud Spill . . . . . . . . . . . . . . . . . 15

3-1 Risk-Based Corrective Action Decision Process $\ldots \ldots \ldots \ldots \ldots \ldots \ldots$

3-2 Conceptual Site Model Flow Chart for CAU $553 \ldots . \ldots \ldots \ldots \ldots \ldots$. . . . . . . 25

3-3 Conceptual Site Model Diagram for CAU $553 \ldots \ldots \ldots \ldots \ldots \ldots$

B.2-1 Nevada Test Site Map with CAU 553 CAS Locations . . . . . . . . . . . . . B-3

B.3-1 Site Conceptual Model . . . . . . . . . . . . . . . . . . . . .

B.9-1 Proposed Sample Locations CAS 19-99-01 . . . . . . . . . . . . . . B-38

B.9-2 Proposed Sample Locations CAS $19-99-11 \ldots \ldots \ldots \ldots \ldots \ldots \ldots \ldots$. . . . . . . . . .

B.9-3 Proposed Sample Locations CAS 20-09-09 . . . . . . . . . . . . . . . . B-40

B.9-4 Proposed Sample Locations CAS $20-99-03 \ldots \ldots \ldots \ldots \ldots \ldots \ldots \ldots$. . . . . . . . . . 


\section{List of Tables}

Number

Title

Page

ES.1-1 Summary of Conceptual Site Model Assumptions and Expected Closures .... ES-3

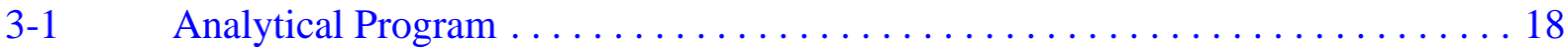

3-2 Analytes Reported by Analytical Methods ................... 19

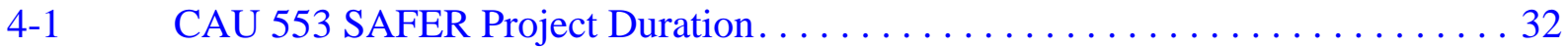

6-1 Waste Management Regulations and Requirements . . . . . . . . . . 36

7-1 Laboratory and Analytical Performance Criteria for CAU 553 DQIs. . . . . . . 45

7-2 Analytical Requirements for Radionuclides for CAU $553 \ldots \ldots \ldots \ldots$

7-3 Analytical Requirements for Chemical COPCs for CAU $553 \ldots \ldots \ldots . . .48$

B.3-1 Data Quality Objective Meeting Participants for CAU 553 July 27, 2006 . . . . . B-8

B.3-2 Analytical Program . . . . . . . . . . . . . . . . . . .

B.3-3 Physical Setting of CAU 553 Corrective Action Sites . . . . . . . . . . . . B-14

B.3-4 Future Land-Use and Exposure Scenarios. . . . . . . . . . . . . B-16

B.5-1 Analytes Reported by Analytical Methods .................... B-23

B.6-1 Spatial Boundaries of CAU 553 Mud Pits and Cellars . . . . . . . . . . . B-25

B.9-1 Summary of Sampling Approach and Data Evaluation for CAU 553. . . . . . . B-35 


\section{List of Acronyms and Abbreviations}

\begin{tabular}{|c|c|}
\hline bgs & Below ground surface \\
\hline CAI & Corrective Action Investigation \\
\hline CAS & Corrective Action Site \\
\hline CAU & Corrective Action Unit \\
\hline CFR & Code of Federal Regulations \\
\hline $\mathrm{COC}$ & Contaminant of concern \\
\hline COPC & Contaminant of potential concern \\
\hline CSM & Conceptual site model \\
\hline DOE & U.S. Department of Energy \\
\hline DOT & U.S. Department of Transportation \\
\hline DQI & Data quality indicator \\
\hline DQO & Data quality objective \\
\hline DRO & Diesel-range organics \\
\hline EPA & U.S. Environmental Protection Agency \\
\hline FAL & Final action level \\
\hline FFACO & Federal Facility Agreement and Consent Order \\
\hline FSR & Field-screening result \\
\hline $\mathrm{ft}$ & Foot \\
\hline $\mathrm{ft}^{2}$ & Square foot \\
\hline HWAA & Hazardous waste accumulation area \\
\hline IDW & Investigation-derived waste \\
\hline in. & Inch \\
\hline LANL & Los Alamos National Laboratory \\
\hline LCS & Laboratory control sample \\
\hline LLNL & Lawrence Livermore National Laboratory \\
\hline MDC & Minimum detectable concentration \\
\hline
\end{tabular}




\section{List of Acronyms and Abbreviations (Continued)}

\begin{tabular}{|c|c|}
\hline $\mathrm{mg} / \mathrm{kg}$ & Milligram per kilogram \\
\hline mi & Mile \\
\hline $\mathrm{mrem} / \mathrm{yr}$ & Millirem per year \\
\hline MS & Matrix spike \\
\hline MSD & Matrix spike duplicate \\
\hline NAC & Nevada Administrative Code \\
\hline NCRP & National Council on Radiation Protection and Measurement \\
\hline NDEP & Nevada Division of Environmental Protection \\
\hline NNSA/NSO & $\begin{array}{l}\text { U.S. Department of Energy, National Nuclear Security Administration } \\
\text { Nevada Site Office }\end{array}$ \\
\hline NTS & Nevada Test Site \\
\hline NTSWAC & Nevada Test Site Waste Acceptance Criteria \\
\hline PAL & Preliminary action level \\
\hline PCB & Polychlorinated biphenyl \\
\hline POC & Performance Objective for the Certification of Nonradioactive Hazardous Waste \\
\hline $\mathrm{PPE}$ & Personal protective equipment \\
\hline ppm & Parts per million \\
\hline PRG & Preliminary remediation goal \\
\hline QA & Quality assurance \\
\hline QAPP & Quality Assurance Project Plan \\
\hline QC & Quality control \\
\hline RadCon & Radiological Control \\
\hline RBCA & Risk-based corrective action \\
\hline RBCSR & Risk-Based Closure Strategy Report \\
\hline RCA & Radiologically Controlled Area \\
\hline RCRA & Resource Conservation and Recovery Act \\
\hline RL & Reporting limit \\
\hline
\end{tabular}




\section{List of Acronyms and Abbreviations (Continued)}

RMA Radioactive Material Area

RSM Rad-Safe Marker

SAFER Streamlined Approach for Environmental Restoration

SDWS Safe Drinking Water Standards

SS Site Supervisor

SSTL Site-specific target level

SVOC Semivolatile organic compound

TPH Total petroleum hydrocarbons

TSCA Toxic Substances Control Act

USGS U.S. Geological Survey

VOC Volatile organic compound 


\section{Executive Summary}

This Streamlined Approach for Environmental Restoration (SAFER) Plan addresses closure for Corrective Action Unit (CAU) 553, Areas 19, 20 Mud Pits and Cellars, identified in the Federal Facility Agreement and Consent Order. Corrective Action Unit 553 consists of four Corrective Action Sites (CASs) located in Areas 19 and 20 of the Nevada Test Site as follows:

- 19-99-01, Mud Spill

- 19-99-11, Mud Spill

- 20-09-09, Mud Spill

- 20-99-03, Mud Spill

This plan provides the methodology for field activities needed to gather the necessary information for closing each CAS. There is sufficient information and process knowledge from historical documentation and investigations of similar sites regarding the expected nature and extent of potential contaminants to recommend closure of CAU 553 using the SAFER process.

The data quality objective process developed for this CAU identified the following expected closure options: (1) investigation and confirmation that no contamination exists above the preliminary action levels leading to a no further action declaration, or (2) characterization of the nature and extent of contamination leading to closure in place with use restrictions. The expected closure options were selected based on available information including contaminants of potential concern (COPCs), future land use, and assumed risks. A decision flow process was developed to outline the collection of data necessary to achieve closure. There are two decisions that need to be answered for closure. Decision I is to determine whether COPCs are present in concentrations exceeding the final action levels (FALs). If COPCs are found to be present above FALs, Decision II will be to determine the extent of contamination and generate all other information necessary to complete closure of the site.

The following text summarizes the types of activities that will support the closure of CAU 553:

- Perform site preparation activities (e.g., build hazardous waste accumulation area).

- $\quad$ Remove and dispose of bentonite waste at CAS 20-09-09 as a best management practice. 
- Collect environmental samples from designated target populations (i.e., mud) to confirm or disprove the presence of contaminants of concern (COCs) (i.e., nature of contamination) as necessary to supplement existing information.

- If COCs exist, collect environmental samples from designated target populations (e.g., clean soil adjacent to contaminated soil) and submit for laboratory analyses to define the extent of COC contamination.

- Establish no further action as the corrective action if no contaminants are detected above FALs.

- If a COC is present at a CAS, and removal is not feasible, establish closure in place as the corrective action and implement the appropriate use restrictions.

- Confirm the preferred closure option is sufficient to protect human health and the environment.

- Document all closure activities for CAU 553 in a Closure Report.

Historical information and process knowledge identified sources of potential contamination for the mud spills. See Table ES.1-1 for a summary of the conceptual site model assumptions and expected closures.

Under the Federal Facility Agreement and Consent Order, the SAFER Plan will be submitted to the Nevada Division of Environmental Protection (NDEP) for approval. Fieldwork will be conducted following approval of the plan. On completion of the field activities, a Closure Report will be prepared and submitted to NDEP for review and approval. 
Table ES.1-1

Summary of Conceptual Site Model Assumptions and Expected Closures

\begin{tabular}{|c|c|c|c|}
\hline $\begin{array}{l}\text { Corrective Action } \\
\text { Site }\end{array}$ & $\begin{array}{c}\text { Potential Release of } \\
\text { COCs }\end{array}$ & $\begin{array}{c}\text { Conceptual Site Model } \\
\text { Assumptions }\end{array}$ & $\begin{array}{l}\text { Expected } \\
\text { Closure }\end{array}$ \\
\hline $\begin{array}{l}\text { Mud Spills: } 19-99-01 \text {, } \\
\text { 19-99-11, 20-09-09, and } \\
20-99-03\end{array}$ & $\begin{array}{l}\text { Primary source for potential } \\
\text { radiological contamination } \\
\text { is a release of drilling mud } \\
\text { associated with drilling } \\
\text { activities subsequent to } \\
\text { underground testing. } \\
\text { Primary source for total } \\
\text { petroleum hydrocarbons is } \\
\text { a release of drilling mud in } \\
\text { which diesel was added as } \\
\text { a lubricant. } \\
\text { The locations of a release } \\
\text { are expected to be limited } \\
\text { to drilling muds. }\end{array}$ & $\begin{array}{l}\text { Contamination at a mud spill is } \\
\text { expected to be bound within the } \\
\text { residual mud (i.e., would not migrate } \\
\text { vertically downward into the underlying } \\
\text { soil). } \\
\text { Lateral extent of contamination is } \\
\text { expected to be limited to the extent of } \\
\text { the drilling mud spill. } \\
\text { Based on results from previous } \\
\text { investigations, no COCs are } \\
\text { anticipated. Note: Verification } \\
\text { samples will be collected and analyzed } \\
\text { for a limited suite of analytes to confirm } \\
\text { the absence of COCs. }\end{array}$ & $\begin{array}{l}\text { No further action } \\
\text { with a contingency } \\
\text { for closure in place } \\
\text { with use restriction }\end{array}$ \\
\hline
\end{tabular}

$\mathrm{COC}=$ Contaminant of concern 


\subsection{Introduction}

This Streamlined Approach for Environmental Restoration (SAFER) Plan addresses the actions necessary for the closure of Corrective Action Unit (CAU) 553: Areas 19, 20 Mud Pits and Cellars, Nevada Test Site (NTS), Nevada. It has been developed in accordance with the Federal Facility Agreement and Consent Order (FFACO) (1996) that was agreed to by the State of Nevada, the U.S. Department of Energy (DOE), and the U.S. Department of Defense.

A SAFER may be performed when the following criteria are met:

- Conceptual corrective actions are clearly identified (although some degree of investigation may be necessary to select a specific corrective action before completion of the Corrective Action Investigation [CAI])

- Uncertainty of the nature, extent, and corrective action must be limited to an acceptable level of risk

- The SAFER Plan includes decision points and criteria for making data quality objective (DQO) decisions

The purpose of the investigation will be to document and verify the adequacy of existing information; to affirm the decision for clean closure, closure in place, or no further action; and to provide sufficient data to implement the corrective action. The actual corrective action selected will be based on characterization activities implemented under this SAFER Plan. This SAFER Plan identifies decision points developed in cooperation with the Nevada Department of Environmental Protection (NDEP), where the DOE, National Nuclear Security Administration Nevada Site Office (NNSA/NSO) will reach consensus with the NDEP before beginning the next phase of work.

Corrective Action Unit 553 is located in Areas 19 and 20 of the NTS, approximately 65 miles (mi) northwest of Las Vegas, Nevada (Figure 1-1). Corrective Action Unit 553 is comprised of the four Corrective Action Sites (CASs) shown on Figure 1-1 and listed below:

- 19-99-01, Mud Spill

- 19-99-11, Mud Spill

- 20-09-09, Mud Spill

- 20-99-03, Mud Spill 


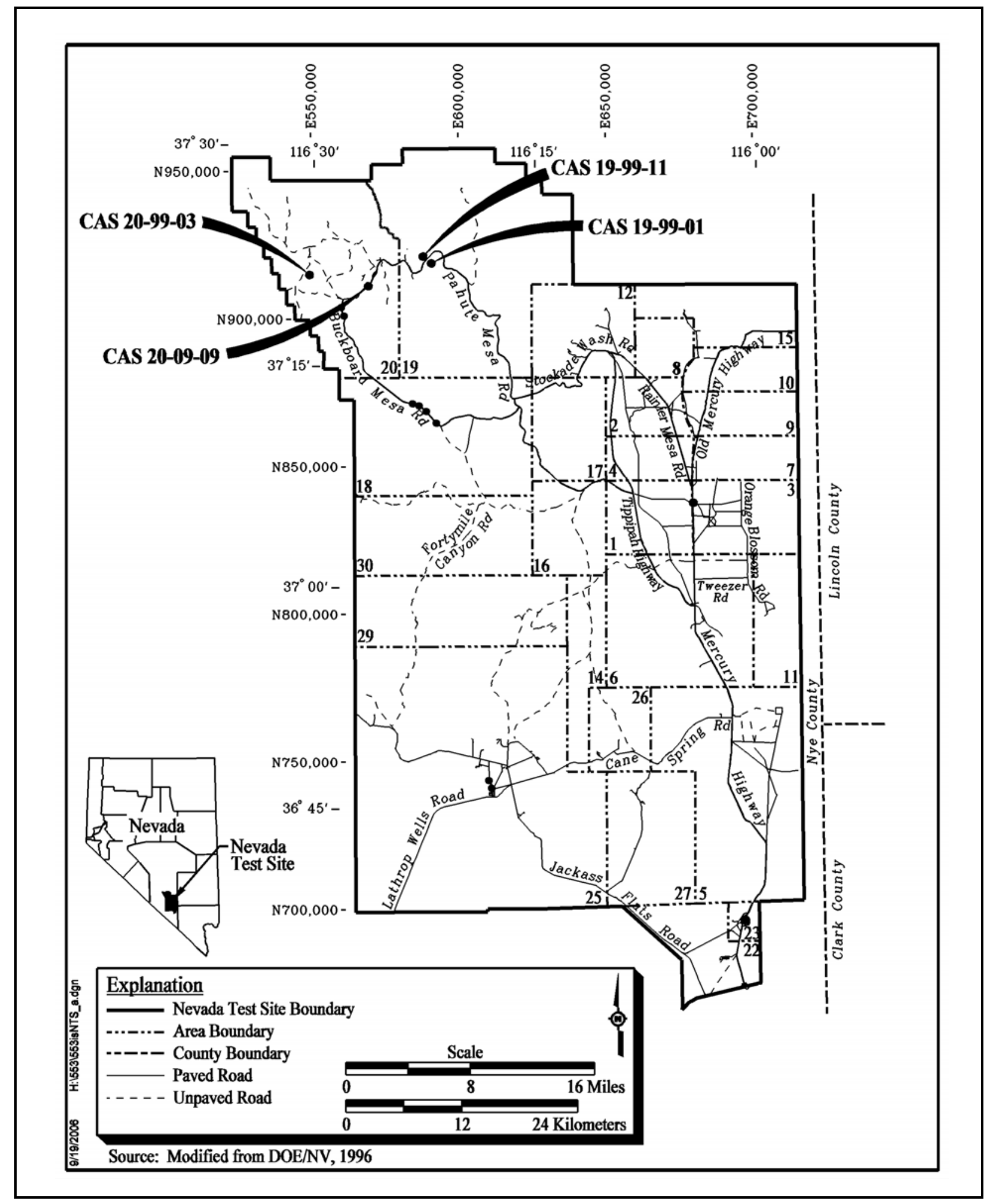

Figure 1-1

Nevada Test Site Map with CAU 553 CAS Locations 
There is sufficient information and process knowledge from historical documentation and investigations of similar sites (i.e., the expected nature and extent of contaminants of potential concern [COPCs]) to recommend closure of CAU 553 using the SAFER process (FFACO, 1996).

\subsection{SAFER Process Description}

Corrective action units that may be closed using the SAFER process have conceptual corrective actions that are clearly identified. Consequently, corrective action alternatives can be chosen before completing a CAI, given anticipated investigation results.

The SAFER process combines elements of the DQO process and the observational approach to plan and conduct closure activities. The DQOs are used to identify the problem and define the type and quality of data needed to complete closure of each CAS. The purpose of the investigation phase is to verify the adequacy of existing information used to determine the chosen corrective action and to confirm that closure objectives were met.

Use of the SAFER process allows for technical decisions to be made based on incomplete but sufficient information, and the experience of the decision-maker. Based on a detailed review of historical documentation, there is sufficient process knowledge to close CAU 553 using the SAFER process. Any uncertainties are addressed by documented assumptions that are verified by sampling and analysis, data evaluation, and on-site observations, as necessary. Closure activities may proceed simultaneously with site characterization as sufficient data are gathered to confirm or disprove the assumptions made during selection of the corrective action. If at any time during the closure process, new information is discovered that indicates that closure activities should be revised, closure activities will be re-evaluated as appropriate.

\subsection{Summary of Corrective Actions and Closures}

The decision process for closure of CAU 553 is summarized in Figure 1-2. This process starts with the initial investigation in which the appropriate target population(s) within each CAS (defined in the DQO process, Appendix B) is sampled. If contaminants are detected at concentrations that are above the final action levels (FALs) and remediation is feasible, the nature and extent of contamination will be delineated by additional sampling. However, contingencies are built into the process in the event 


\section{SAFER Decision Flow Logic Diagram}

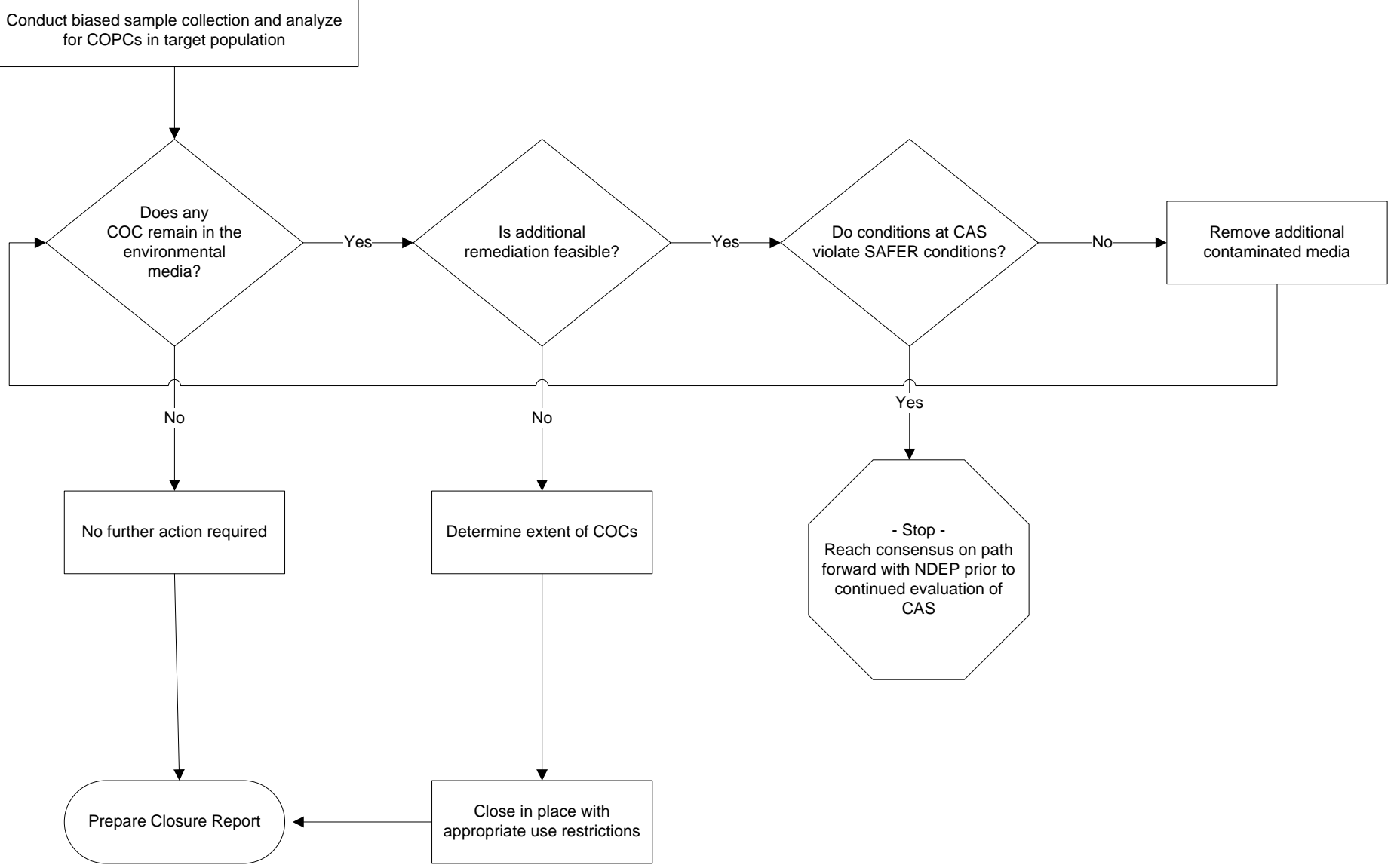

Figure 1-2

CAU 553 Closure Decision Process 
new information is identified that indicates that the selected closure option should be revised. The process ends with closure of the site based on laboratory analytical results of the environmental samples and the preparation of a Closure Report. Corrective action alternatives of closure in place and clean closure will be evaluated for each CAS with contaminants above FALs.

Decision points that require a consensus be reached between the NNSA/NSO and NDEP before continuing are indicated in Figure 1-2.

In addition to the previously discussed hold/decision points, work may be temporarily suspended until the issue can be satisfactorily resolved, if any of the following unexpected conditions occur:

- Conditions outside the scope of work are encountered.

- Radiological screening yields results that require an upgrade in procedures to continue survey work in specific areas.

- Elevated levels of additional contaminants of concern (COCs) are found that were not originally identified as being present at the sites.

- Unexpected conditions including unexpected waste and/or contamination are encountered.

- Out-of-scope work activities are required due to the detection of other COCs, that would require re-evaluating a disposal pathway, such as with hazardous or low-level waste.

- Unsafe conditions or work practices.

The CASs in CAU 553 are anticipated to be closed with the designation no further action based on the application of process knowledge and previous site investigation results from similar CASs in CAUs 530-535 and CAU 177. Applying process knowledge and the assumptions and results from previous mud pit investigations is expected to result in there being no required activity at these CASs. A contingency is in place for individual mud spills to be closed in place with implementation of use restrictions if a COC is present and there is sufficient information to establish the boundaries of contamination. 
Assumptions relating mud spills to the processes involved with NTS mud pits that serve as the basis for this investigation are:

- Mud spills in CAU 553 are considered to have resulted from essentially the same process as mud pits. A mud spill is an incidental release of drilling mud that was once contained (e.g., in a truck or tank), whereas a mud pit is a structure excavated into the ground to facilitate mud circulation during borehole drilling. This assumes the mud within the spill areas may have been used in the drilling process; however, the spills are not contained within a bermed mud pit.

- Any drilling fluid present in the mud was homogenized during the mixing or drilling operations.

- Due to the physical properties of the affected media (mud), contamination, if present, is expected to be bound within the matrix of the residual mud with no significant lateral or vertical migration.

- Verification sampling will be adequate to support the absence of chemical and radiological COPCs (including total petroleum hydrocarbons [TPH]-diesel-range organics [DRO]). Results of previous mud pit investigations support the elimination of chemical constituents as COPCs. Because the mud spills are not posted as radioactive material areas (RMAs), and recent walkover survey results indicate no elevated radioactivity, radionuclides are not expected to be present. 


\subsection{Unit Description}

The operational history, process knowledge, and existing information for each CAS are summarized in this section. Each CAS is the direct release of drilling mud potentially impacted by TPH-DRO and radiological contamination. Process knowledge for the CASs in CAU 553 has been obtained through historical document reviews, engineering drawing and map reviews, and interviews with past and present NTS employees. Some uncertainty remains regarding specific knowledge of past operations for this CAU. Site-specific historical documentation pertaining to each CAS is also limited; however, it is assumed that the mud spills are associated with drilling activities at the NTS. Based on the process knowledge and information about the CASs and using the Mud Pit Risk-Based Closure Strategy Report (RBCSR) (NNSA/NSO, 2004a), assumptions were made to formulate a conceptual site model (CSM) that describes the most probable scenario for the current conditions at each CAS. Section 3.2.5 provides additional information on the CSM developed for the CASs in CAU 553.

\subsection{General Description}

This section provides a description of information relating the mud pit process to the mud spills in each CAS.

\subsubsection{Mud Pit Process and Contaminant Release}

The mud spills of CAU 553 are assumed to have similar releases as those identified for the NTS mud pits in CAUs 530-535 and CAU 177. It is unknown whether the spills occurred before or after use in the drilling process where diesel and/or radioactivity may have been released. It can also be reasonably assumed the spill material composition is similar (i.e., mud/clay composition and properties) regardless if the release was associated with pre- or post-test drilling activities.

Although the RBCSR eliminated volatile organic compounds (VOCs), semivolatile organic compounds (SVOCs), polychlorinated biphenyls (PCBs), and metals as COPCs from NTS mud pits (based on the conclusion that there is no analytical or process knowledge to suggest these constituents are present at significant concentrations in residual mud), TPH was the most frequently detected contaminant in residual mud. To be conservative, it was determined that the investigation of CAU 553 would evaluate the risk posed by TPH-DRO and verify the closure strategy of no further 
action for CAU 553 mud pits. Because complete information regarding activities performed at the CAU 553 mud spills is not available, VOCs, SVOCs, and radiological constituents will also be included as COPCs.

The process associated with potential contamination at a mud pit is assumed to be the same process that may have contributed to contamination at a mud spill. Section B.3.2.1 addresses the release of contaminants associated with the drilling mud in more detail.

\subsection{CAS 19-99-01, Mud Spill}

\subsubsection{Description and Location}

Corrective Action Site 19-99-01 consists of the environmental release associated with a mud spill located on and surrounding a dirt mound located in Area 19 adjacent to the north side of the fenced U-19ad potential crater area east of Pahute Mesa Road. The release may contain TPH and potentially radioactive constituents based on process knowledge of mud pits and drilling processes.

The mud spill is located on top of a dirt mound and the spill extends downslope in several directions with a small portion extending past the U-19ad fenceline. The dirt mound is approximately 8 feet (ft) high and covers an area of approximately 1,250 square feet $\left(\mathrm{ft}^{2}\right)$. Scattered vegetation is growing on and around the dirt mound and within the mud. Several pieces of debris are visible within the area, and the presence of a dirt mound suggests that the ground surface has been disturbed. Surface soil, including the mound, consists of light-brown to pinkish-brown, silt to sand size volcanic material. Figure 2-1 shows the CAS boundaries and physical layout.

\subsubsection{History and Process Knowledge}

The area was used for conducting an underground weapons-related test at U-19ad. The Los Alamos National Laboratory (LANL) Chancellor test was conducted on September 1, 1983, as a part of Operational Phalanx (DOE/NV, 2000). Based on proximity, CAS 19-99-01 mud spill is believed to be associated with pre- and/or post-test drilling activities at U-19ad; however, several other tests were conducted in the vicinity of the mud spill and drilling activities at these tests may have contributed to the release of drilling mud. Therefore, the mud spill release is assumed to be similar in operation and composition to NTS mud pit material (DOE/NV, 2001). 


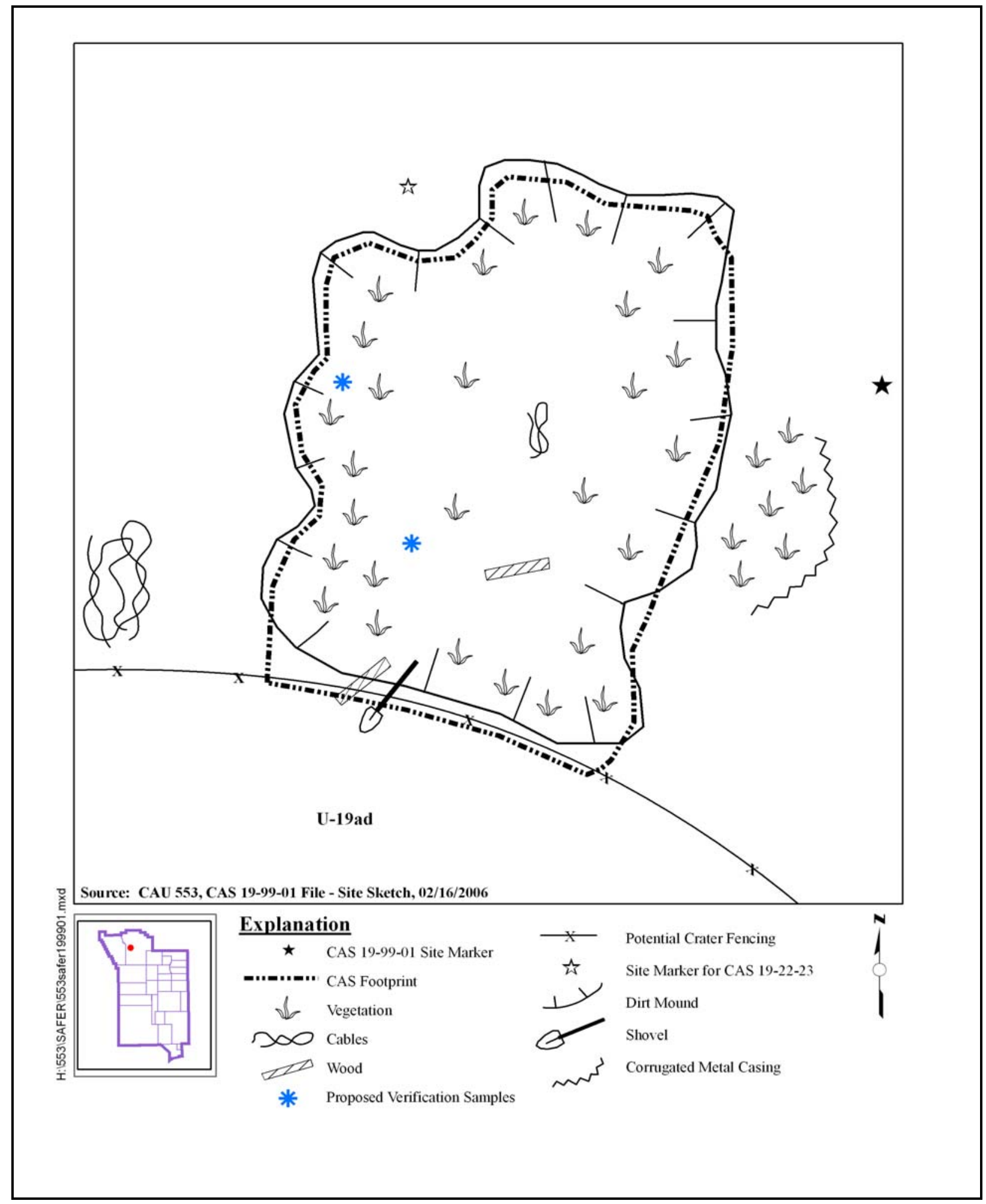

Figure 2-1

Corrective Action Site 19-99-01, Mud Spill 


\subsubsection{Available Characterization Information}

Geophysical surveys were conducted in 2002 (Shaw) and 2006 (Fahringer) and identified one anomaly to the west of the mound, most likely due to corrugated metal casing partially visible at the surface. No other buried metal was detected below the soil mound. A radiological survey conducted at the site identified elevated gamma readings in the southeast corner of the site; however, based on these surveys, it was determined that the radiological readings are below two times background (Alderson, 2002). No soil analytical results were identified for this CAS.

\subsection{CAS 19-99-11, Mud Spill}

\subsubsection{Description and Location}

Corrective Action Site 19-99-11 consists of the environmental releases associated with three mud spills located approximately $50 \mathrm{ft}$ east of the fenced U-19q/U-19q PS\#1D potential crater area (REECo, 1991). The releases may contain TPH and potentially radioactive constituents based on process knowledge of mud pits and drilling processes.

The CAS is located in Area 19 west of the Pahute Mesa Road near the U-19q potential crater area. The three separate mud spills are referred to as the south, north, and west spills and have a total area of approximately $1,167 \mathrm{ft}^{2}$. The south mud spill is the smallest and measures approximately $216 \mathrm{ft}^{2}$ and consists of a thin, weathered layer of brown-gray powdery mud that overlies a cracked, harder layer of darker gray mud. The west spill is approximately $458 \mathrm{ft}^{2}$ and consists of a 1-ft-thick layer of crumbled gray mud overlying a 3-ft mound of native soil. The north spill is approximately $493 \mathrm{ft}^{2}$ and appears to consist of gray grout aggregate with areas of yellow staining. Black wire and wood fencing debris are visible on the surface. Figure 2-2 shows the CAS boundaries and the physical layout.

\subsubsection{History and Process Knowledge}

The area was used for conducting an underground weapons-related test at U-19q. The Lawrence Livermore National Laboratory (LLNL) Camembert test was conducted on June 26, 1975, as a part of Operation Bedrock (DOE/NV, 2000). Based on proximity, CAS 19-99-11 mud spill is believed to be associated with post-test drilling activities at drill hole U-19q PS\#1D. Therefore, the mud spill 


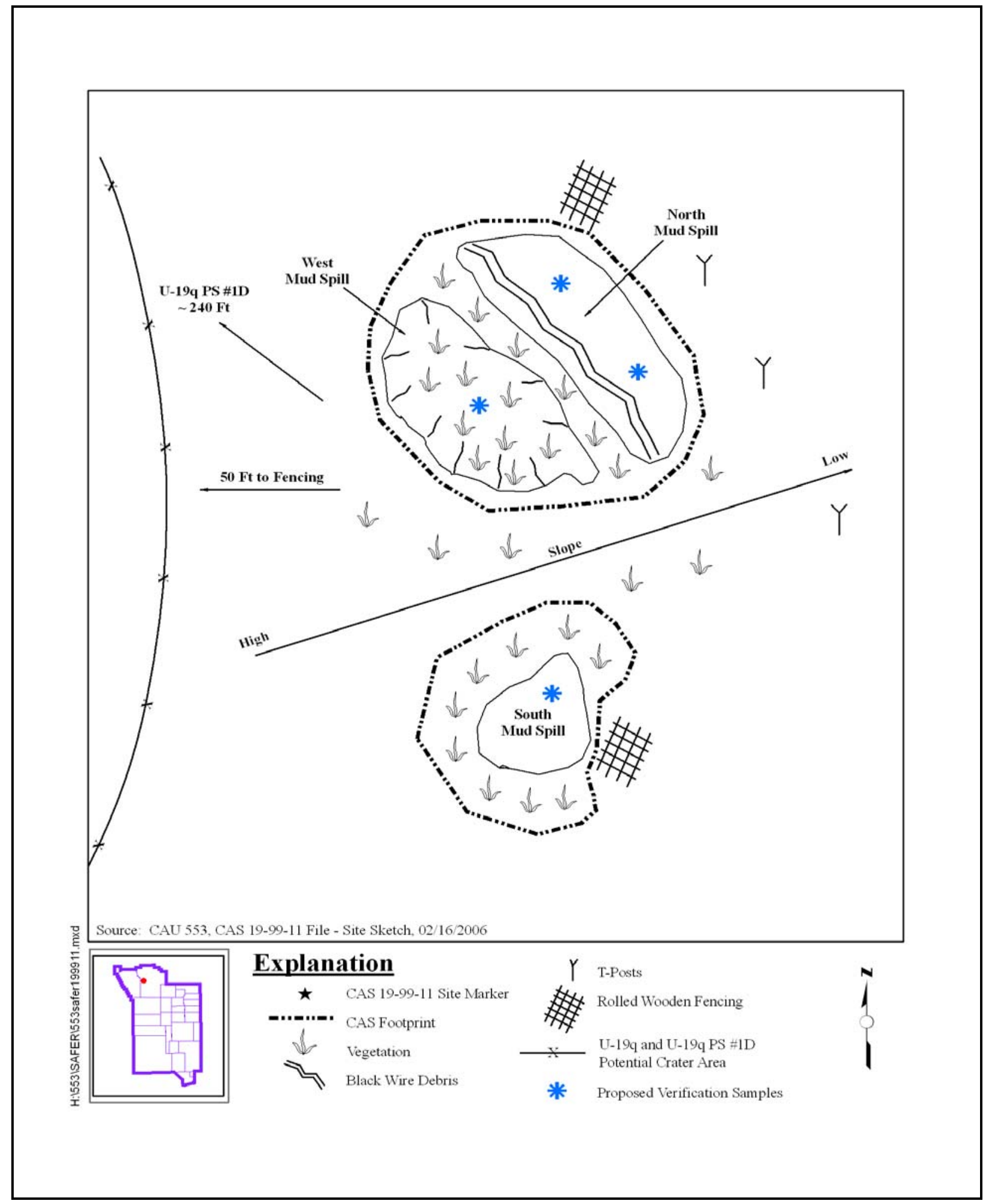

Figure 2-2

Corrective Action Site 19-99-11, Mud Spill 
release is assumed to be operationally and compositionally similar to NTS mud pit material (DOE/NV, 2001).

\subsubsection{Available Characterization Information}

No site-specific geophysical or radiological surveys or analytical results were identified for this CAS.

\subsection{CAS 20-09-09, Mud Spill}

\subsubsection{Description and Location}

Corrective Action Site 20-09-09 consists of the environmental release associated with two bentonite mud spills located approximately $20 \mathrm{ft}$ south of mud mixing plants at the Area 20 Pahute Mesa Mud Plant (REECo, 1992).

The site is located in the Pahute Mesa Mud Plant at Rad-Safe Marker (RSM) 20 P 114 in Area 20 and consists of two dry substance spills of dry, cracked gray bentonite on the ground surface. The dimensions of the each spill are approximately 3 by $12 \mathrm{ft}$ and 2 to 12 inches (in.) thick. The dimensions are easily visible compared to the graded pad/road surface. The soil within and around the site appears to be native volcanic rock. Figure 2-3 shows the CAS boundaries and the physical layout.

\subsubsection{History and Process Knowledge}

The site is the location of the inactive Pahute Mesa Mud Plant at which mud mixing and water distribution operations for drilling activities in Pahute Mesa were conducted (Geary, 1965). Mud was generated at the plant for use in Area 20 drilling activities. Drilling mud is typically a combination of powdered bentonite clay mixed with water to form a viscous fluid (REECo, 1994). The dry substance spill is believed to have resulted from these mud mixing activities and not used in actual drilling processes. Currently, the site is marked as a DOE Operational Readiness Area.

\subsubsection{Available Characterization Information}

No site-specific geophysical or radiological surveys or analytical results were identified for this CAS. 


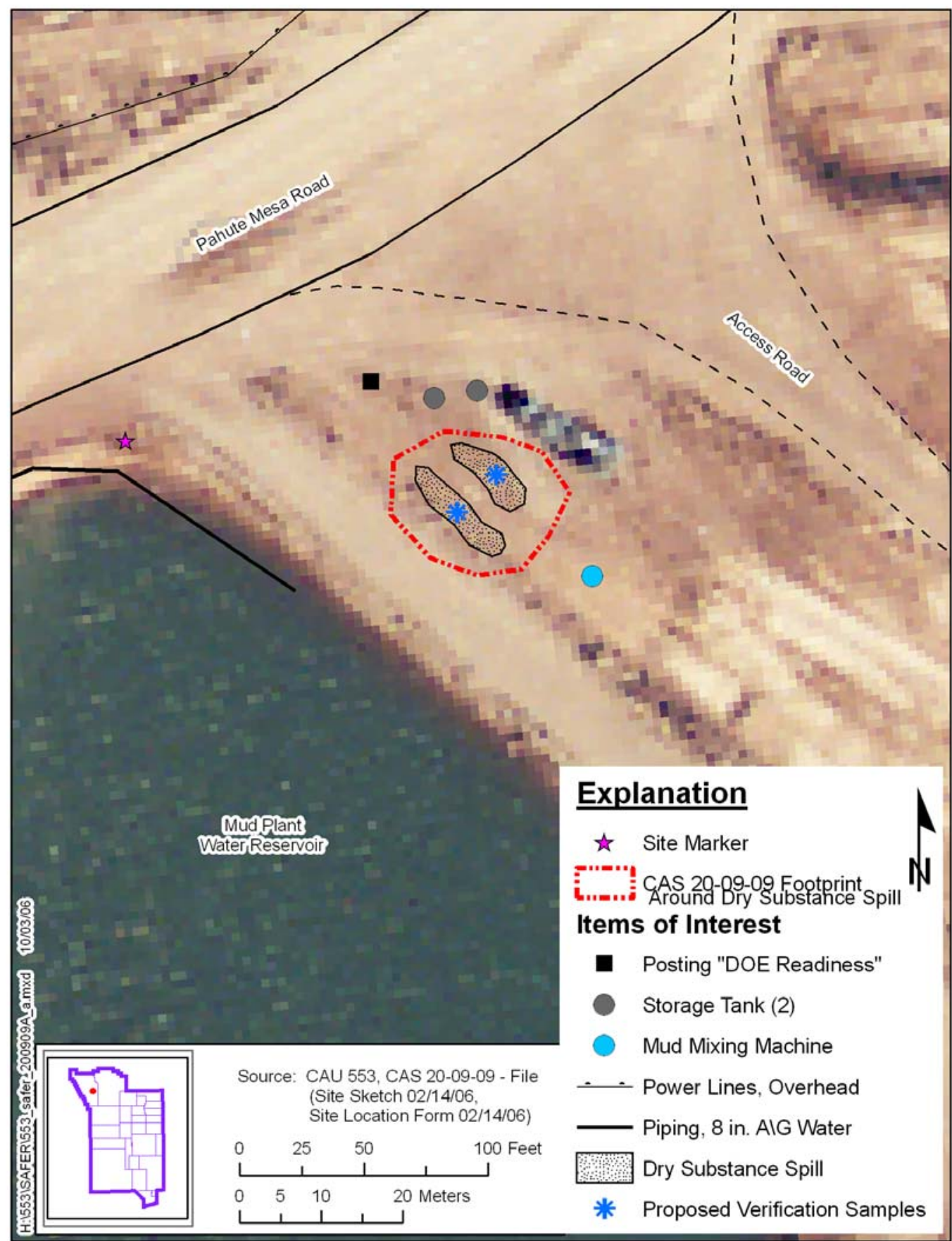

Figure 2-3

Corrective Action Site 20-09-09, Mud Spill 


\subsection{CAS 20-99-03, Mud Spill}

\subsubsection{Description and Location}

Corrective Action Site 20-99-03 consists of a potential environmental release associated with the mud spill located southeast of the fenced U-20aq crater area (REECo, 1991). The release may contain $\mathrm{TPH}$ and potentially radioactive constituents based on process knowledge of mud pits and drilling processes.

The mud spill is located in Area 20 south of the U-20aq crater area and consists of one continuous area of dried mud on the ground surface. The spill area measures approximately 750 by $300 \mathrm{ft}$ and is light pinkish-brown clay/silty material, dry, and cracked. The thickness varies between 1 to 6 in. thick. A pile of small steel pellets (based on visual observations of rust) is located on the northeast side of the spill but does not represent a health hazard. The dimensions of the mud spill are easily visible against the native black/red volcanic surface and an active dirt road dissects the spill in half. Figure 2-4 shows the CAS boundaries and the physical layout.

\subsubsection{History and Process Knowledge}

The area was used for conducting the underground Darwin test by LLNL and the United Kingdom on June 25, 1986, in U-20aq (DOE/NV, 2000; RSN, 1991). Based on proximity to U-20aq, CAS 20-99-03 mud spill is believed to be associated with post-test drilling activities at U-20aq. There is a potential that mud may have been drained in this area from metal piping used in drilling operations to direct the drilling fluids/cuttings from the drill hole to the mud pit. Another possibility is that a holding tank containing drill mud may have spilled in the area. Therefore, the mud spill release is assumed to be similar in operation and composition to NTS mud pit material (DOE/NV, 2001).

\subsubsection{Available Characterization Information}

No geophysical survey or analytical results were identified for this CAS. A radiological survey was conducted in 2006, and based on these surveys, it was determined that the radiological readings are below two times background (SNJV, 2006). 


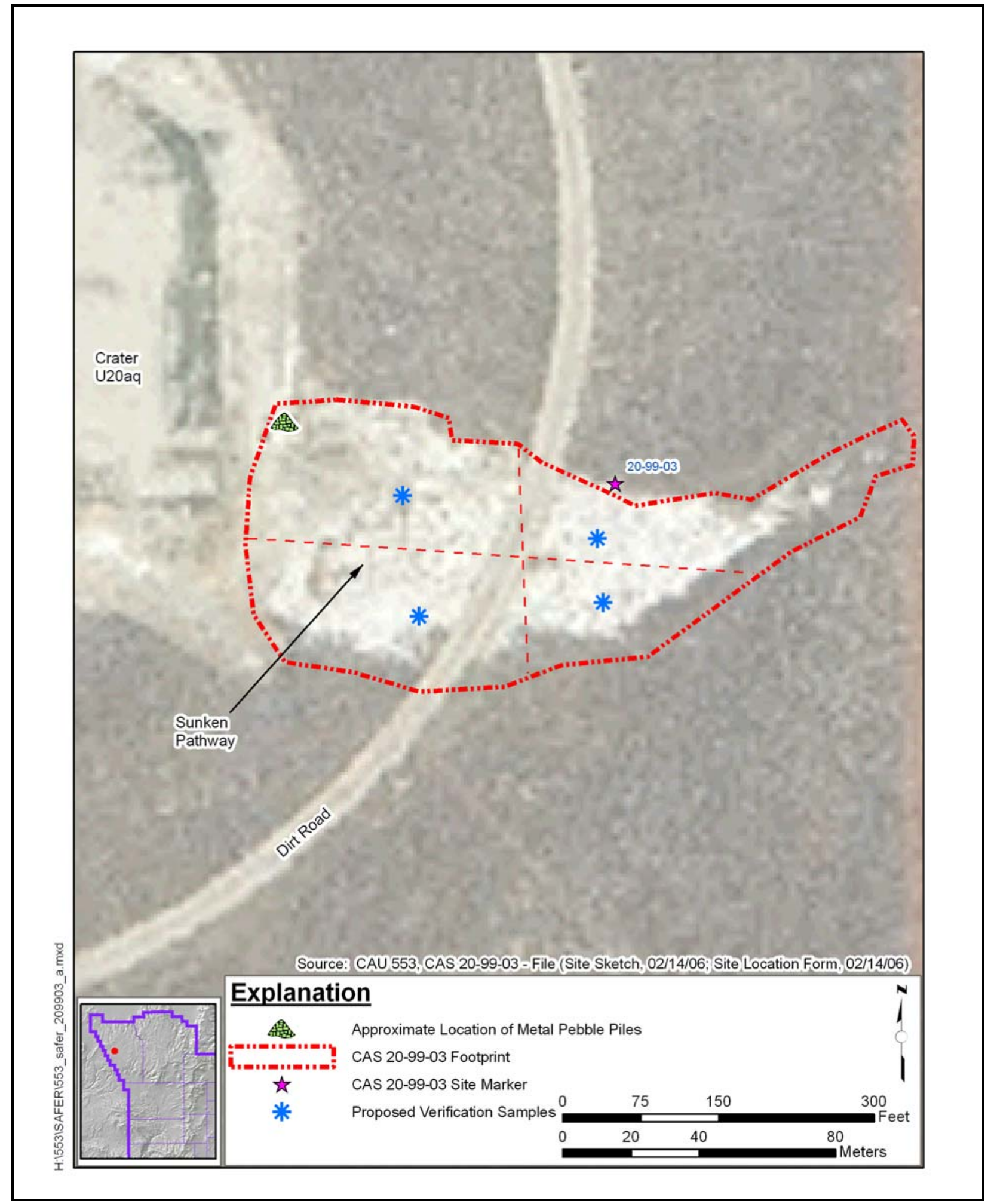

Figure 2-4

Corrective Action Site 20-99-03, Mud Spill 


\subsection{Data Quality Objectives}

\subsection{Summary of DQO Analysis}

This section contains a summary of the DQO process presented in Appendix B. The DQO process is a strategic planning approach based on the scientific method that is designed to ensure that the data collected will provide sufficient and reliable information to identify, evaluate, and technically defend the recommendation of viable corrective actions (e.g., no further action, clean closure, or closure in place).

The DQO strategy for CAU 553 was developed at a meeting on July 27, 2006. The DQOs were developed to identify data needs, clearly define the intended use of the environmental data, and to design a data collection program that will satisfy these purposes. During the DQO discussions for this CAU, the informational inputs or data needs to resolve problem statements and decision statements were documented.

The problem statement for CAU 553 is: "Sufficient historical and analytical information is available to support a No Further Action closure alternative for all CASs in CAU 553; however, verification samples are required to confirm the absence of COCs at levels that could pose a risk to human health or the environment." To address this question, the resolution of two decisions statements is required:

- Decision I: “Is any COPC present in environmental media within a mud spill at a concentration exceeding its corresponding action level?” No further action will be supported if no COPCs are identified above corresponding action levels. For the judgmental sampling design, any analytical result for a COPC above the FAL will result in that COPC being designated as a COC. If a COC is detected and remediation is feasible, then contaminated media may be removed for disposal and additional samples collected (refer to Figure 1-2). If a COC is detected and remediation is not feasible, then Decision II must be resolved.

- Decision II: "If a COC is present, is sufficient information available to meet closure objectives?” Sufficient information is defined to include:

- Identifying the volume of media containing COCs, as bounded by analytical results in lateral and vertical directions

- Information needed to characterize investigation-derived waste (IDW) for disposal 
- Information needed to determine remediation waste types

- Information needed to evaluate the feasibility of potential closure options

The presence of a COC would require a corrective action. A corrective action may also be necessary if there is a potential for wastes that are present at a site to release COCs into site environmental media. To evaluate the potential for site wastes to result in the introduction of a COC to the surrounding environmental media, the following conservative assumptions were made:

- Any containment of the wastes would fail at some point and the wastes would be released to the surrounding media.

- The resulting concentration of contaminants in the surrounding media would be equal to the concentration of contaminants in the waste.

- Any liquid waste contaminant concentrations exceeding the Resource Conservation and Recovery Act (RCRA) toxicity characteristic leaching potential would result in COCs in the surrounding media.

Waste solids containing a contaminant exceeding an equivalent FAL concentration would be considered to be potential source material and would require a corrective action. Waste liquids with contaminant concentrations exceeding an equivalent toxicity characteristic leaching potential action level would be considered to be potential source material and would require a corrective action.

Decision I verification samples will be submitted to analytical laboratories for the analyses listed in Table 3-1. The constituents reported for each analytical method are listed in Table 3-2.

The list of COPCs is intended to encompass all of the contaminants that could potentially be present at each CAS. These COPCs were identified during the planning process through the review of site history, process knowledge, personal interviews, past investigation efforts (where available), and inferred activities associated with the CASs. Contaminants detected at other similar or other NTS sites were also included in the COPC list to reduce the uncertainty about potential contamination at the CASs because complete information regarding activities performed at the CAU 553 sites is not available.

During the review of site history, process knowledge information, personal interviews, past investigation efforts, and inferred activities associated with the CASs, none of the COPCs were 
Table 3-1

Analytical Program ${ }^{\mathrm{a}}$

\begin{tabular}{|c|c|c|c|c|}
\hline Analyses $^{b}$ & $\begin{array}{l}\text { 혐 } \\
\text { ò } \\
\text { ơ่ } \\
\text { ò }\end{array}$ & 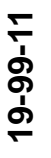 & 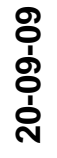 & $\begin{array}{l}\text { 어 } \\
\text { ơ } \\
\text { ò }\end{array}$ \\
\hline \multicolumn{5}{|l|}{ Organic COPCs } \\
\hline Total Petroleum Hydrocarbons (Diesel-Range Organics) & $X$ & $\mathrm{X}$ & $\mathrm{X}$ & $\mathrm{x}$ \\
\hline Semivolatile Organic Compounds ${ }^{c}$ & $\mathrm{X}$ & $\mathrm{X}$ & $\mathrm{X}$ & $\mathrm{x}$ \\
\hline Volatile Organic Compounds ${ }^{c}$ & $X$ & $X$ & $X$ & $\mathrm{X}$ \\
\hline \multicolumn{5}{|c|}{ Radionuclide COPCs } \\
\hline Gamma Spectroscopy & $\mathrm{X}$ & $\mathrm{X}$ & $\mathrm{X}$ & $\mathrm{X}$ \\
\hline Isotopic Uranium & $\mathrm{X}$ & $\mathrm{X}$ & $\mathrm{X}$ & $\mathrm{x}$ \\
\hline Isotopic Plutonium & $X$ & $\mathrm{X}$ & $\mathrm{X}$ & $x$ \\
\hline Strontium-90 & $X$ & $X$ & $X$ & $x$ \\
\hline
\end{tabular}

${ }^{\mathrm{a}}$ The contaminants of potential concern are the analytes reported from the analytical methods listed in Table 3-2.

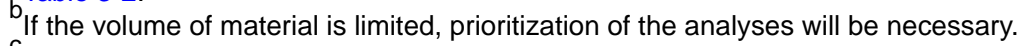

${ }^{c}$ May also include Toxicity Characteristic Leaching Procedure analytes if sample is collected for waste management purposes.

$\mathrm{COPC}=$ Contaminant of potential concern $X=$ Required analytical method

identified as targeted contaminants at specific CASs. Targeted contaminants are those COPCs for which evidence in the available site and process information suggests that they may be reasonably suspected to be present at a given CAS. The targeted contaminants are required to meet a more stringent completeness criteria than other COPCs, thus providing greater protection against a decision error (see Appendix B). There are no targeted contaminants for CAU 553 CAS.

Decision II samples, if collected, will be submitted for the analysis of all unbounded COCs. In addition, samples will be submitted for analyses as needed to support waste management or health and safety decisions.

The data quality indicators (DQIs) of precision, accuracy, representativeness, completeness, comparability, and sensitivity needed to satisfy DQO requirements are discussed in Section 7.2. Laboratory data will be assessed in the Closure Report to confirm or refute the CSM and determine whether the DQO data needs were met. 
Table 3-2

Analytes Reported by Analytical Methods

\begin{tabular}{|c|c|c|c|c|}
\hline \multicolumn{2}{|c|}{ VOC } & SVOC & TPH & Radionuclides \\
\hline $\begin{array}{l}\text { 1,1,1-Trichloroethane } \\
\text { 1,1,1,2-Tetrachloroethane } \\
\text { 1,1,2,2-Tetrachloroethane } \\
\text { 1,1,2-Trichloroethane } \\
\text { 1,1-Dichloroethane } \\
\text { 1,1-Dichloroethene } \\
\text { cis-1,2-Dichloroethene } \\
\text { 1,2-Dichloroethane } \\
\text { 1,2-Dichloropropane } \\
\text { 1,2,4-Trichlorobenzene } \\
\text { 1,2,4-Trimethylbenzene } \\
\text { 1,2-Dibromo-3-chloropropane } \\
\text { 1,3,5-Trimethylbenzene } \\
\text { 1,4-Dioxane } \\
\text { 2-Butanone } \\
\text { 2-Chlorotoluene } \\
\text { 2-Hexanone } \\
\text { 4-Methyl-2-pentanone } \\
\text { Acetone } \\
\text { Acetonitrile } \\
\text { Allyl chloride } \\
\text { Benzene } \\
\text { Bromodichloromethane } \\
\text { Bromoform } \\
\text { Bromomethane } \\
\text { Carbon disulfide } \\
\text { Carbon tetrachloride } \\
\text { Chlorobenzene } \\
\text { Chloroethane } \\
\text { Chloroform } \\
\text { Chloromethane } \\
\text { Isopropylbenzene } \\
\text { Methacrylonitrile } \\
\text { Methyl methacrylate } \\
\text { Dibromochloromethane } \\
\text { Ethyl methacrylate } \\
\text { Ithylbenzene } \\
\text { I,3) } \\
\text { I, }\end{array}$ & $\begin{array}{l}\text { Methylene chloride } \\
\text { N-Butylbenzene } \\
\text { N-Propylbenzene } \\
\text { o-Dichlorobenzene }(1,2) \\
\text { p-Dichlorobenzene }(1,4) \\
\text { p-isopropyltoluene } \\
\text { sec-Butylbenzene } \\
\text { Styrene } \\
\text { tert-Butylbenzene } \\
\text { Tetrachloroethene } \\
\text { Toluene } \\
\text { Total Xylenes } \\
\text { Trichloroethene } \\
\text { Trichlorofluoromethane } \\
\text { Vinyl acetate } \\
\text { Vinyl chloride }\end{array}$ & 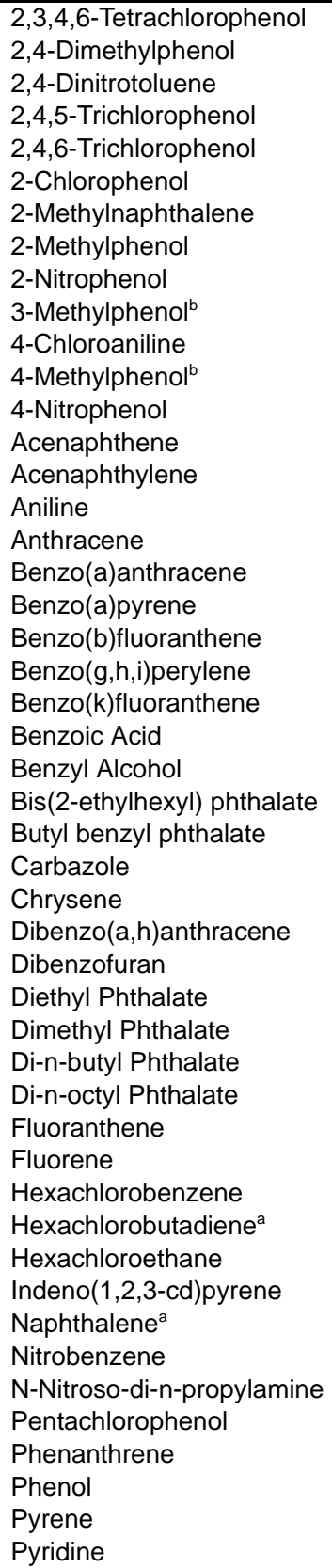 & $\begin{array}{l}\text { TPH } \\
\text { (Diesel-Range } \\
\text { Organics }\end{array}$ & $\begin{array}{l}\text { Plutonium-238 } \\
\text { Plutonium-239/240 } \\
\text { Strontium-90 } \\
\text { Uranium-234 } \\
\text { Uranium-235 } \\
\text { Uranium-238 } \\
\text { Other parameters: } \\
\text { Gamma-emitting } \\
\text { radionuclides } \\
\text { including: } \\
\text { Actinium-228 } \\
\text { Americium-241 } \\
\text { Cesium-137 } \\
\text { Cobalt-60 } \\
\text { Europium-152 } \\
\text { Europium-154 } \\
\text { Europium-155 } \\
\text { Lead-212 } \\
\text { Lead-214 } \\
\text { Niobium-94 } \\
\text { Potassium-40 } \\
\text { Thallium-208 } \\
\text { Thorium-234 } \\
\text { Uranium-235 }\end{array}$ \\
\hline
\end{tabular}

a May be reported with VOCs

${ }^{\mathrm{b}}$ May be reported as 3,4-methylpenol
SVOC = Semivolatile organic compound

$\mathrm{TPH}=$ Total petroleum hydrocarbons

VOC $=$ Volatile organic compound 
To satisfy the DQI of sensitivity (Section 7.2.6), the analytical methods must be sufficient to detect contamination that is present in the samples at concentrations equal to the corresponding FALs. Analytical methods and minimum detectable concentrations (MDCs) for each CAU 553 COPC are provided in Tables 7-2 and 7-3. The MDC is the lowest concentration of a chemical or radionuclide parameter that can be detected in a sample within an acceptable level of error. Due to changes in analytical methodology and changes in analytical laboratory contracts, information in Tables 7-2 and 7-3 that varies from corresponding information in the Quality Assurance Project Plan (QAPP) will supersede that information in the Industrial Sites QAPP (NNSA/NV, 2002a).

\subsection{Results of the DQO Analysis}

\subsubsection{Action Level Determination and Basis}

The preliminary action levels (PALs) presented in this section are to be used for site screening purposes. They are not necessarily intended to be used as cleanup action levels or FALs. However, they are useful in screening out contaminants that are not present in sufficient concentrations to warrant further evaluation, therefore streamlining the consideration of remedial alternatives. The risk-based corrective action (RBCA) process used to establish FALs is described in the Industrial Sites Project Establishment of Final Action Levels (NNSA/NSO, 2006b). This process conforms with Nevada Administrative Code (NAC) Section 445A.227, which lists the requirements for sites with soil contamination (NAC, 2005). For the evaluation of corrective actions, NAC Section 445A.22705 recommends the use of ASTM Method E 1739-95 to "conduct an evaluation of the site, based on the risk it poses to public health and the environment, to determine the necessary remediation standards (i.e., FALs) or to establish that corrective action is not necessary” (ASTM, 1995).

This RBCA process, summarized in Figure 3-1, defines three tiers (or levels) of evaluation involving increasingly sophisticated analyses:

- Tier 1 - Sample results from source areas (highest concentrations) are compared to action levels based on generic (non-site-specific) conditions (i.e., the PALs established in the SAFER. The FALs may then be established as the Tier 1 action levels or the FALs may be calculated using a Tier 2 evaluation.

- $\quad$ Tier 2 - Conducted by calculating Tier 2 site-specific target levels (SSTLs) using site-specific information as inputs to the same or similar methodology used to calculate Tier 1 action 


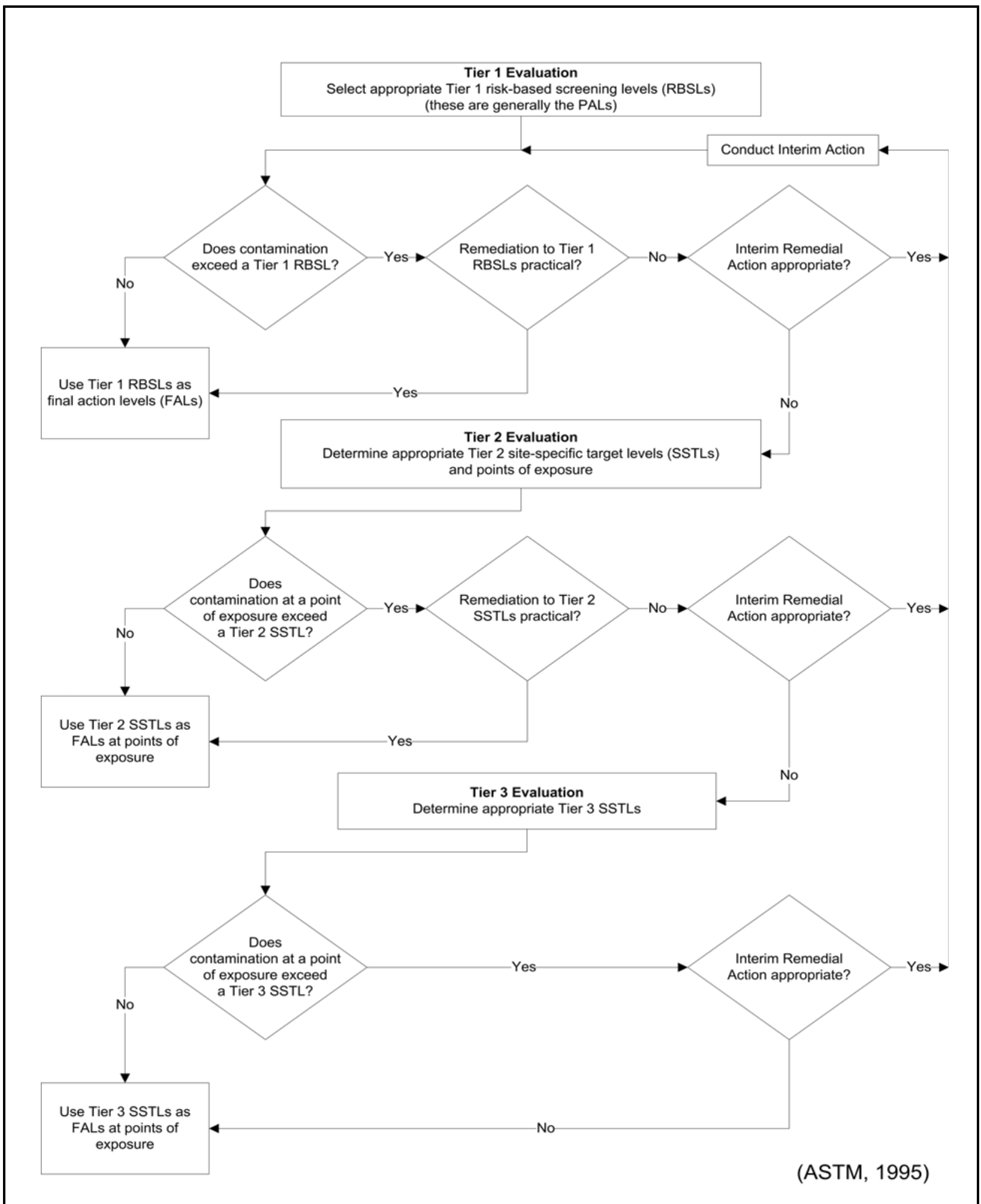

Figure 3-1

Risk-Based Corrective Action Decision Process 
levels. The Tier 2 SSTLs are then compared to individual sample results from reasonable points of exposure (as opposed to the source areas as is done in Tier 1) on a point by point basis. Total TPH concentrations will not be used for risk-based decisions under Tier 2 or Tier 3. Rather, the individual chemicals of concern will be compared to the SSTLs.

- $\quad$ Tier 3 - Conducted by calculating Tier 3 SSTLs on the basis of more sophisticated risk analyses using methodologies described in Method E1739-95 that consider site-, pathway-, and receptor-specific parameters.

Evaluation of DQO decisions will be based on conditions at the site following completion of any corrective actions. Any corrective actions conducted will be reported in the Closure Report. The FALs (along with the basis for their selection) will be defined in the Closure Report, where they will be compared to laboratory results in the evaluation of site closure.

\subsubsection{Chemical PALs}

Except as noted herein, the chemical PALs are defined as the U.S. Environmental Protection Agency (EPA) Region 9 Risk-Based Preliminary Remediation Goals (PRGs) for chemical contaminants in industrial soils (EPA, 2004). For detected chemical COPCs without established PRGs, the protocol used by the EPA Region 9 in establishing PRGs (or similar) will be used to establish PALs. If used, this process will be documented in the Closure Report.

\subsubsection{Total Petroleum Hydrocarbon PALs}

The PAL for TPH is 100 parts per million (ppm) as listed in NAC 445A.2272 (NAC, 2005).

\subsubsection{Radionuclide PALs}

The PALs for radiological contaminants are based on the National Council on Radiation Protection and Measurement (NCRP) Report No. 129 recommended screening limits for construction, commercial, industrial land-use scenarios (NCRP, 1999) using a 25 millirem per year (mrem/yr) dose constraint (Murphy, 2004) and the generic guidelines for residual concentration of radionuclides in DOE Order 5400.5 (DOE, 1993). These PALs are based on the construction, commercial, and industrial land-use scenario provided in the guidance, and are appropriate for the NTS, based on future land uses presented in Section B.3.2.5. 
Solid media such as concrete and/or structures may pose a potential radiological exposure risk to site workers if contaminated. The radiological PAL for solid media will be defined as the unrestricted-release criteria defined in the NV/YMP Radiological Control (RadCon) Manual (NNSA/NSO, 2004b).

\subsubsection{Hypothesis Test}

The baseline condition (i.e., null hypothesis) and alternative condition are:

- Baseline condition - A COC is present

- Alternative condition - A COC is not present

The baseline condition (i.e., null hypothesis) and alternative condition for Decision II are as follows:

- $\quad$ Baseline condition - The extent of a COC has not been defined.

- Alternative condition - The extent of a COC has been defined.

\subsubsection{Statistical Model}

A judgmental sampling design will be implemented to select sample locations and evaluate DQO decisions for all mud spills within the CAU 553 CASs. The sampling design will assume that the data are not normally distributed and that the statistical test will be to compare results to a fixed threshold (FALs).

\subsubsection{Design Description/Option}

\subsubsection{Judgmental Sampling}

Because individual sample results rather than an average concentration will be used to compare to FALs at the CASs undergoing judgmental sampling, statistical methods to generate site characteristics will not be used. Adequate representativeness of the entire target population may not be a requirement to developing a sampling design. If good prior information is available on the target site of interest, then the sampling may be designed to collect samples only from areas known to have the highest concentration levels on the target site. If the observed concentrations from these samples are below the action level, then a decision can be made that the site contains safe levels of the contaminant without the samples being truly representative of the entire area (EPA, 2006). 
All sample locations will be selected to satisfy the DQI of representativeness in that samples collected from selected locations will best represent the populations of interest as defined in Section B.6.1. To meet this criterion for judgmental sampling sites, a biased sampling strategy will be used for Decision I samples to target areas with the highest potential for contamination, if it is present in the CAS. Sample locations will be determined based on process knowledge, previously acquired data, or the field-screening and biasing factors listed in Section B.5.2.1. If biasing factors are present in soils below locations where Decision I samples were removed, additional Decision I soil samples may be collected at depth intervals selected by the Site Supervisor (SS) based on biasing factors to a depth where they are no longer present. The SS has the discretion to modify the judgmental sample locations, but only if the modified locations meet the decision needs and criteria stipulated in this DQO.

\subsubsection{Conceptual Site Model and Drawing}

The CSM describes the most probable scenario for current conditions at each site and defines the assumptions that are the basis for identifying the future land use, contaminant sources, release mechanisms, migration pathways, exposure points, and exposure routes. The CSM is also used to support appropriate sampling strategies and data collection methods. A single CSM has been developed for CAU 553 using information from the physical setting, potential contaminant sources, release information, historical background information, knowledge from similar sites, and physical and chemical properties of the potentially affected media and COPCs. Figure 3-2 depicts a tabular representation of the conceptual pathways to receptors from CAU 553 sources. Figure 3-3 depicts a graphical representation of the CSM. If evidence of contamination that is not consistent with the presented CSM is identified during investigation activities, the situation will be reviewed, the CSM revised, DQOs re-assessed, and a recommendation made as to how best to proceed. In such cases, participants in the DQO process will be notified and given the opportunity to comment on and/or concur with the recommendation. A detailed discussion of the elements of the CSM is presented in Appendix B. 


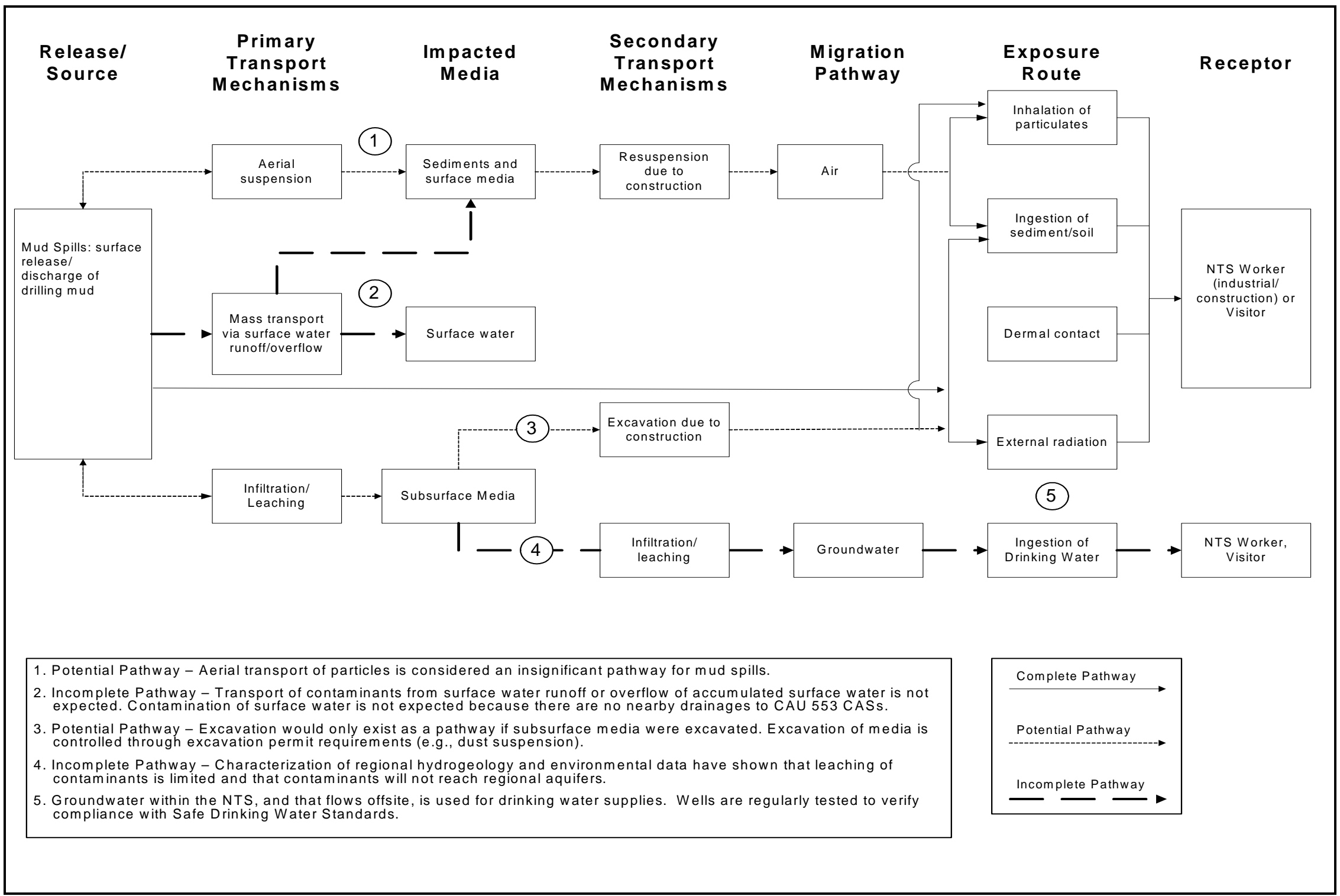

Figure 3-2

Conceptual Site Model Flow Chart for CAU 553 


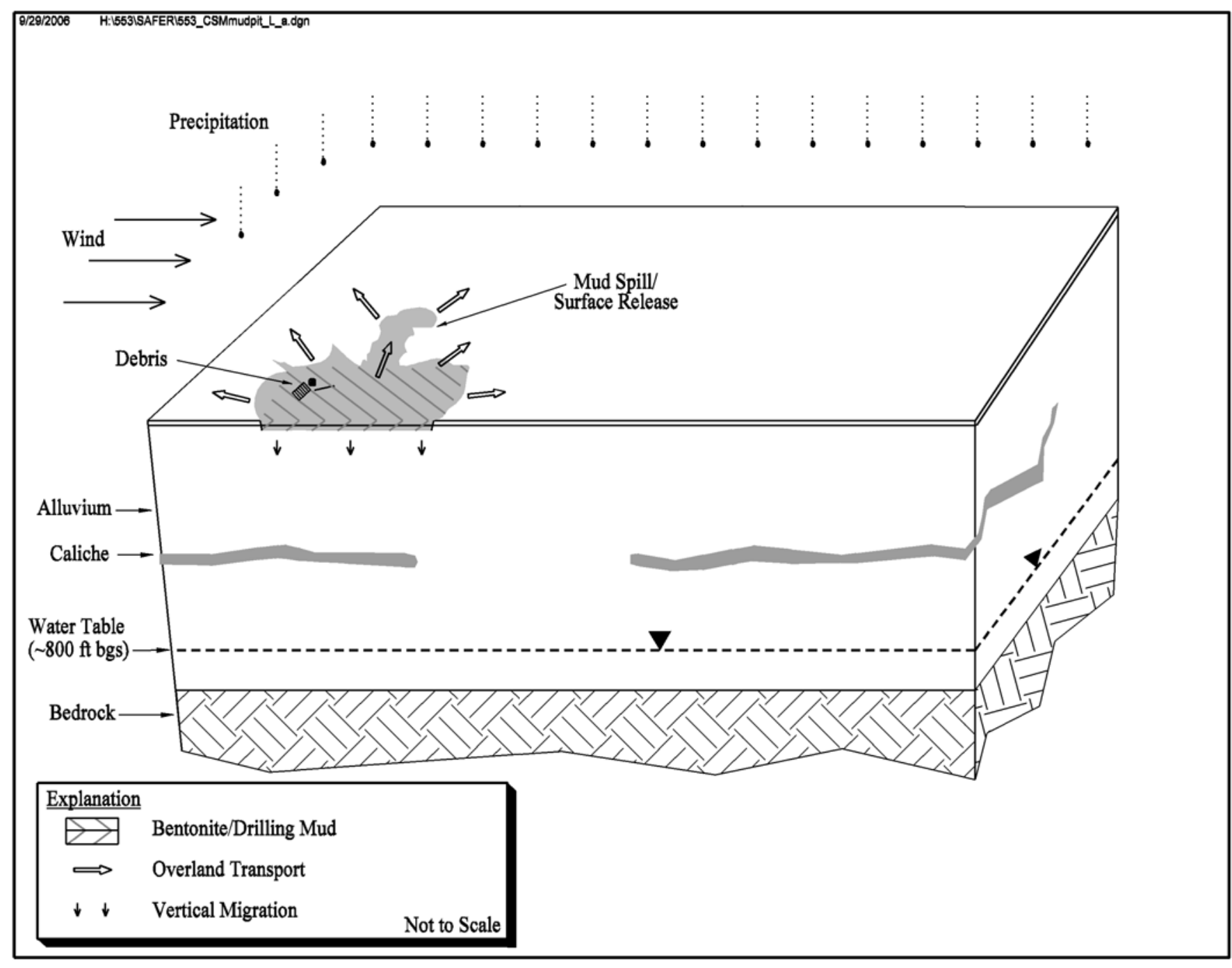

Figure 3-3

Conceptual Site Model Diagram for CAU 553 


\subsection{Field Activities and Closure Objectives}

This section of the SAFER Plan provides a description of the field activities and closure objectives for CAU 553. The objectives for the field activities are to determine whether COCs exist. If remediation is determined to be feasible, then the extent of COCs will be determined so that a closure alternative may be implemented. All sampling activities will be conducted in compliance with the Industrial Sites QAPP (NNSA/NV, 2002b) and other applicable, approved procedures and instructions.

\subsection{Contaminants of Potential Concern}

The COPCs applicable to Decision I environmental samples from each mud spill of CAU 553 are defined as the analytes reported from the analyses identified in Table 3-1. The constituents reported for each analyses are listed in Tables 3-2 and B.5-1. The list of COPCs is intended to encompass all of the contaminants that could potentially be present at each CAS. These COPCs were identified during the planning process through the review of site history, process knowledge, past investigation efforts (where available), and inferred activities associated with the CASs. Contaminants detected at other similar NTS mud pit/spill sites were also included in the COPC list to reduce the uncertainty about potential contamination at the CASs because complete information regarding activities performed at the CAU 553 sites is not available. A detailed discussion of the selection of COPCs is presented in Appendix B.

Target analytes are those contaminants for which evidence and available site and process information suggests that they may be reasonably suspected to be present at a given CAS. The targeted contaminants are required to meet a more stringent completeness criteria than other COPCs, thus providing greater protection against a decision error. For this investigation, no targeted analytes have been identified.

\subsection{Remediation}

The DQOs developed for CAU 553 identified data gaps that require additional data collection before identifying and implementing the preferred closure alternative for each CAS. A decision point approach, based on the DQOs, for making remediation decisions is summarized in Figure 1-2. The 
presence of contamination, if any, is assumed to be confined to the spatial boundaries of the sites as defined in the DQO process and CSM. According to DQO guidelines (Appendix B), judgmental sampling will be conducted at all CASs. As a best management practice, the bentonite grout/mud as CAS 20-09-09 will be removed and disposed as waste because it is located within a potential work area.

If COCs are identified within a CAS based on the initial investigation results, that CAS will be further assessed before implementing closure activities. If COPCs are not present at concentrations exceeding FALs, the CAS will be recommended for no further action. The objective of the initial investigation strategy is to determine whether COCs are present. Laboratory analytical results will be used to confirm the presence or absence of COCs.

If COCs are present, or it is decided that COCs may be present based on the presence of biasing factors, a corrective action of removal for disposal may be implemented and additional verification samples taken from biased locations within the excavation. Alternatively, the CAS will be recommended for closure in place with administrative controls.

If a COC is present and removal of the COC is not feasible, information on the extent of COC contamination will be obtained by collecting step-out (Decision II) samples. Decision II sampling will consist of further defining the extent of contamination where COCs have been confirmed. Step-out (Decision II) sampling locations at each CAS will be selected based on the CSM, biasing factors, field-screening results (FSRs), existing data, and the outer boundary sample locations where COCs were detected. In general, step-out sample locations will be arranged in a triangular pattern around areas containing a COC at distances based on site conditions, COC concentrations, process knowledge, and other biasing factors. If COCs extend beyond step-out locations, additional Decision II samples will be collected from locations further from the source. If a spatial boundary is reached, the CSM is shown to be inadequate, or the SS determines that extent sampling needs to be re-evaluated, work will be temporarily suspended, NDEP will be notified, and the investigation strategy re-evaluated.

The judgmental sampling strategy is presented in Appendix B. Pre-determined biased sample locations may be justified by the SS, based on the criteria for satisfying DQO data needs listed in 
Appendix B. Additional samples may be collected for waste management characterization and disposal purposes.

\subsection{Verification}

Sufficient historical site knowledge and previous sampling results from similar mud pit/spill investigations exist to indicate that the mud spills in CAU 553 can be closed under no further action. However, to support this closure alternative and reduce uncertainty, surface verification samples will be collected using a judgmental sampling design from each individual mud spill within CAU 553 to confirm that COCs are not present at concentrations that pose a risk to human health or the environment. All samples will be surface samples ( 0 to 6 in. below ground surface [bgs]) of the residual mud and will be collected by hand scoop, hand auger, or other appropriate method. Site preparation activities are expected to be limited to the construction of temporary site exclusion zones, visual surveys of each mud spill to identify biasing factors, and radiological surveys at each sample location for health and safety purposes.

The following sections outline the judgmental sample design for each CAS and also describes any additional activities that may be performed as best management practices (i.e., removal of solid material). During the investigation for all CASs in CAU 553, the SS has the discretion to modify the sample locations or order additional biased samples to be collected, but only if the new locations meet the decision needs and criteria stipulated in this DQO. The SS will use professional judgment to determine whether biasing factors (e.g., stains, elevated screening levels) are found during Decision I sampling that might indicate the need to take subsurface Decision II samples. The final locations and numbers of verification samples to be collected will be determined in the field based on the presence of any biasing factors as listed in Section B.5.2.1. The number and location of verification samples will be justified in the Closure Report.

Because this SAFER Plan only addresses contamination originating from the CAU, it may be necessary to distinguish overlapping contamination originating from other sources. For example, widespread surface radiological contamination originating from atmospheric tests will not be addressed in the CAU 553 investigation. To determine whether contamination is from the CAU or from other sources, soil samples may be collected from background locations at selected CASs. 
Modifications to the investigation strategy may be required should unexpected field conditions be encountered at any CAS. Significant modifications shall be justified and documented in a Record of Technical Change before implementation. If an unexpected condition indicates that conditions are significantly different than the corresponding CSM, the activity will be rescoped and the decision makers will be notified. Field activities at CAU 553 include site preparation, sample location selection, sample collection activities, waste characterization, photo-documentation, and collection of geo-spatial coordinates.

\subsubsection{CAS 19-99-01, Mud Spill}

The mud spill at this CAS is not contiguous and is located in several areas on and surrounding an 8-ft-high soil mound. The thickest concentrations of mud/clay material can be found in localized shallow depressions atop the mound and low areas on the ground surface at the base of the mound where the mud spilled down the sides. A minimum of two biased samples will be collected from the mound area with the locations biased towards staining, elevated FSRs, and/or the thickest deposits of mud assuming any COPCs will be concentrated in these areas. Debris surrounding the mud spill within the CAS boundaries will not be removed or investigated. Geophysical surveys of the mound indicate no debris is buried, and the nature of the mud spill suggests that mud was deposited only on the mound surface. Figure B.9-1 shows the proposed sample locations.

\subsubsection{CAS 19-99-11, Mud Spill}

This CAS has three distinct mud spill areas. Verification samples will be collected from each spill in a location with the highest potential to find contamination if present. In the absence of staining or elevated FSRs, a sample will be collected in either the topographic low within the spill area where contaminants could be expected to be concentrated or in the center of the spill if no other biasing factors exist. For the North spill, it is anticipated the grout material will be sampled directly in two locations, with at least one location at a yellow-stained area on the north end. For the West spill, the darker gray silt/clay material lying atop the native volcanic material will be sampled. For the South spill, any stained area or the darkest gray coloring of the mud will be sampled. Debris within the CAS boundaries will not be removed or investigated. Figure B.9-2 shows the proposed sample locations. 


\subsubsection{CAS 20-09-09, Mud Spill}

Due to the location of the two bentonite spills within a DOE Operational Readiness Area, it is recommended that both bentonite piles be removed as a best management practice and managed as waste. Based on the dimensions of the bentonite spills, the volume to be removed may fill two to three 55-gallon drums. Samples will be collected directly from the bentonite material for waste management purposes. A soil verification sample will then be collected from beneath each of the removed bentonite piles to confirm the absence of COPCs in the underlying soil. If COCs are shown to be present, then Decision II samples will be collected, if deemed necessary. Figure B.9-3 shows the proposed sample locations.

\subsubsection{CAS 20-99-03, Mud Spill}

The mud spill at this CAS is contiguous and encompasses a large area (750 by $250 \mathrm{ft}$ ) where the mud is distributed relatively evenly across the site. This mud spill is the only area of concern for this CAS. The pile of steel pellets (based on visual observation of rust) located north of the mud spill does not represent an environmental hazard and therefore will not be investigated further. A radiological survey performed on the mud spill indicates no elevated radiological contamination. Based on these data and previous mud pit sampling investigation results, there is no indication that a more extensive characterization of the spill area is necessary. Therefore, only four verification samples are recommended with one sample from each quadrant of the spill area to be collected. See Figure B.9-4 for the proposed sample locations. Biasing factors will be identified during a site walkdown and the proposed locations will be refined based on the site conditions. It is anticipated that most of the verification samples will be collected in pooled, concentrated areas of the mud due to the lack of apparent staining throughout the mud spill.

\subsection{Closure}

The following activities, at a minimum, have been identified for closure of these CASs. The decision logic behind the activities is provided in Figure 1-2:

- If no COCs are detected, the CAS will be closed with no further action.

- If a COC is present, remove if feasible and resample. 
- If removal is not feasible, the extent of COC contamination will be determined and closure-in-place will be implemented. The appropriate use restrictions will be implemented and documented in the Closure Report.

The closure objectives will have been met and the CAS will be proposed for closure if the following conditions are true:

- A COC is not present at a CAS

- A COC is present and the extent of each COC has been defined.

- Information is sufficient to characterize remediation waste and IDW for disposal.

After completion of CAI and waste management activities, the following actions will be implemented before closure of the site Real Estate/Operations Permit:

- Removal of all equipment, wastes, debris, and materials associated with the CAI.

- Grading of site to pre-investigation condition (unless changed condition is necessary under a corrective action).

- Site will be inspected and certified that restoration activities have been completed.

\subsection{Duration}

Table 4-1 is a tentative duration of activities (in work days) for SAFER activities:

Table 4-1

CAU 553 SAFER Project Duration

\begin{tabular}{|c|c|}
\hline Duration (days) & Activity \\
\hline \hline 10 & Site Preparation \\
\hline 76 & Fieldwork Preparation and Mobilization \\
\hline 10 & Sampling \\
\hline 160 & Data Assessment \\
\hline 180 & Waste Management \\
\hline
\end{tabular}




\subsection{Reports and Records Availability}

Historic information and documents referenced in this plan are retained in the NNSA/NSO project files in Las Vegas, Nevada, and can be obtained through written request to the NNSA/NSO Project Manager. This document is available in the DOE public reading rooms located in Las Vegas and Carson City, Nevada, or by contacting the appropriate DOE project manager. The NDEP maintains the official Administrative Record for all activities conducted under the auspices of the FFACO. 


\subsection{Investigation/Remediation Waste Management}

Management of IDW will be based on regulatory requirements, field observations, process knowledge, and laboratory results from CAU 553 investigation samples.

Disposable sampling equipment, personal protective equipment (PPE), and rinsate are considered potentially contaminated waste only by virtue of contact with potentially contaminated media (e.g., soil) or potentially contaminated debris (e.g., construction materials). Therefore, sampling and analysis of IDW, separate from analyses of site investigation samples, may not be necessary for all IDW. However, if associated investigation samples are found to contain contaminants above regulatory levels, conservative estimates of total waste contaminant concentrations may be made based on the mass of the waste, the amount of contaminated media contained in the waste, and the maximum concentration of contamination found in the media. Direct samples of IDW may also be taken to support waste characterization.

Sanitary, hazardous, radioactive, and/or mixed waste, if generated, will be managed and disposed of in accordance with applicable DOE orders, U.S. Department of Transportation (DOT) regulations, state and federal waste regulations, and agreements and permits between DOE and NDEP.

\subsection{Waste Minimization}

Investigation activities are planned to minimize IDW generation. This will be accomplished by incorporating the use of process knowledge, visual examination, and/or radiological survey and swipe results. When possible, disturbed media (such as soil removed during trenching) or debris will be returned to its original location. Contained media (e.g., soil managed as waste) as well as other IDW will be segregated to the greatest extent possible to minimize generation of hazardous, radioactive, or mixed waste. Hazardous material used at the sites will be controlled in order to limit unnecessary generation of hazardous or mixed waste. Administrative controls, including decontamination procedures and waste characterization strategies, will minimize waste generated during investigations. 


\subsection{Potential Waste Streams}

Waste generated during the corrective action activities will include the following potential waste streams:

- Personal protective equipment and disposable sampling equipment (e.g., plastic, paper, sample containers, aluminum foil, spoons, bowls)

- Decontamination rinsate

- Environmental media (e.g., soil, bentonite)

The on-site management and ultimate disposition of wastes will be determined based on a determination of the waste type (e.g., sanitary, low-level, hazardous, hydrocarbon, mixed), or the combination of waste types. A determination of the waste type will be guided by several factors, including, but not limited to: the analytical results of samples either directly or indirectly associated with the waste, historical site knowledge, waste generation process knowledge, field observations, field-monitoring/screening results, and/or radiological survey/swipe results.

Table 4-2 of the NV/YMP RadCon Manual (NNSA/NSO, 2004b) shall be used to determine whether materials may be released to controlled or uncontrolled areas. On-site IDW management requirements by waste type are detailed in the following sections. Applicable waste management regulations and requirements are listed in Table 6-1.

\subsubsection{Sanitary Waste}

Sanitary IDW generated at each CAS will be collected, managed, and disposed of in accordance with the sanitary waste management regulations and the permits for operation of the NTS 10c Industrial Waste Landfill.

Office trash and lunch waste will be placed in the dumpster to be transported to the sanitary landfill for disposal. Sanitary IDW generated at each CAS will only be collected in plastic bags, sealed, labeled with the CAS number from each site in which it was generated, and dated. The waste will then be placed in a roll-off box located in Mercury, or other approved roll-off box location. The number of bags of sanitary IDW placed in the roll-off box will be counted as they are placed in the 
Table 6-1

Waste Management Regulations and Requirements

\begin{tabular}{|c|c|c|}
\hline Waste Type & Federal Regulation & Additional Requirements \\
\hline Solid (nonhazardous) & $\mathrm{N} / \mathrm{A}$ & $\begin{array}{c}\text { NRS }^{\mathrm{a}} 444.440-444.620 \\
\text { NAC }^{\mathrm{b}} 444.570-444.7499 \\
\text { NTS Landfill Permit SW13.097.04 } \\
\text { NTS Landfill Permit SW13.097.03 }\end{array}$ \\
\hline Liquid/Rinsate (nonhazardous) & N/A & $\begin{array}{l}\text { Water Pollution Control General Permit } \\
\text { GNEV93001, Rev. 3iii }\end{array}$ \\
\hline Hazardous & $\begin{array}{c}\text { RCRA }^{f}, \\
40 \text { CFR 260-282 }\end{array}$ & $\begin{array}{c}\text { NRS }^{\mathrm{a}} 459.400-459.600 \\
\text { NAC }^{\mathrm{b}} 444.850-444.8746 \\
\text { POC }^{\mathrm{g}}\end{array}$ \\
\hline Low-Level Radioactive & N/A & DOE Orders and NTSWAC ${ }^{h}$ \\
\hline Mixed & $\begin{array}{c}\text { RCRA }^{f}, \\
40 \text { CFR 260-282 }\end{array}$ & $\begin{array}{l}\text { NTSWAC } \\
\text { POC }^{\mathrm{g}}\end{array}$ \\
\hline Hydrocarbon & $\mathrm{N} / \mathrm{A}$ & $\begin{array}{c}\text { NTS Landfill Permit SW13.097.02 } \\
\text { NAC }^{\mathrm{i}} 445 \mathrm{a} .2272\end{array}$ \\
\hline Polychlorinated Biphenyls & $\begin{array}{l}\text { TSCA }^{\mathrm{j}} \\
40 \text { CFR } 761\end{array}$ & $\begin{array}{l}N_{R S}^{a} 459.400-459.600 \\
\text { NAC }^{b} 444.940-444.9555\end{array}$ \\
\hline Asbestos & $\begin{array}{c}\text { TSCA }^{\mathrm{j}} \\
40 \text { CFR } 763\end{array}$ & $\begin{array}{l}N^{N R S^{a}} 618.750-618.840 \\
\text { NAC }^{b} 444.965-444.976\end{array}$ \\
\hline
\end{tabular}

${ }^{a}$ Nevada Revised Statutes (NRS, 2005a, b, c)

${ }^{\mathrm{b}}$ Nevada Administrative Code (NAC, 2004a and b)

${ }^{\mathrm{c}}$ Area 23 Class II Solid Waste Disposal Site (NDEP, 1997a)

${ }^{d}$ Area 9 Class III Solid Waste Disposal Site (NDEP, 1997c)

eNevada Test Site Sewage Lagoons (NDEP, 1999)

${ }^{\mathrm{f}}$ Resource Conservation and Recovery Act (CFR, 2005a)

${ }^{9}$ Nevada Test Site Performance Objective for the Certification of Nonradioactive Hazardous Waste (BN, 1995)

${ }^{\mathrm{h} N e v a d a}$ Test Site Waste Acceptance Criteria, Rev. 6-01 (NNSA/NSO, 2006c)

'Area 6 Class III Solid Waste Disposal Site for hydrocarbon waste (NDEP, 1997b)

'Toxic Substance Control Act (CFR, 2005b and c)

CFR $=$ Code of Federal Regulations

DOE $=$ U.S. Department of Energy

$\mathrm{N} / \mathrm{A}=$ Not applicable

NAC $=$ Nevada Administrative Code

NRS = Nevada Revised Statutes

NTS $=$ Nevada Test Site
NTSWAC $=$ Nevada Test Site Waste Acceptance Criteria

$\mathrm{POC}=$ Performance Objective for the Certification of Nonradioactive Hazardous Waste

RCRA = Resource Conservation and Recovery Act

TSCA = Toxic Substance Control Act

roll-off box, noted in a log, and documented in the Field Activity Daily Log. These logs will provide necessary tracking information for ultimate disposal in the 10c Industrial Waste Landfill. 


\subsubsection{Low-Level Radioactive Waste}

Radiological swipe surveys and/or direct-scan surveys may be conducted on reusable sampling equipment and the PPE and disposable sampling equipment waste streams exiting a radiologically controlled area (RCA). This allows for the immediate segregation of radioactive waste from waste that may be unrestricted regarding radiological release. Contamination limits, as defined in Table 4-2 of the NV/YMP RadCon Manual (NNSA/NSO, 2004b), will be used to determine whether such waste may be declared unrestricted regarding radiological release versus being declared radioactive waste. Direct sampling of the waste may be conducted to aid in determining whether a particular waste unit (e.g., drum of soil) contains low-level radioactive waste, as necessary. Waste determined to be below the values of Table 4-2, by either direct radiological survey/swipe results or through process knowledge, will not be managed as potential radioactive waste but will be managed in accordance with the appropriate section of this document. Wastes in excess of Table 4-2 values will be managed as potential radioactive waste and be managed in accordance with this section and any other applicable sections of this document.

Low-level radioactive waste, if generated, will be managed in accordance with the contractor-specific waste certification program plan, DOE orders, and the requirements of the current version of the Nevada Test Site Waste Acceptance Criteria (NTSWAC) (NNSA/NSO, 2006c). Potential radioactive waste drums containing soil, PPE, disposable sampling equipment, and/or rinsate may be staged at a designated RMA or RCA when full or at the end of an investigation phase. The waste drums will remain at the RMA pending certification and disposal under NTSWAC requirements (NNSA/NSO, 2006c).

\subsubsection{Hazardous Waste}

The CAU may have waste accumulation areas established according to the needs of the project. Satellite accumulation areas and hazardous waste accumulation areas (HWAAs) will be managed consistent with the requirements of federal and state regulations. (CFR, 2005a; NAC, 2004b). The HWAAs will be properly controlled for access and equipped with spill kits and appropriate spill containment. Suspected hazardous wastes will be placed in DOT-compliant containers. All containerized hazardous waste will be handled, inspected, and managed in accordance with Title 40 CFR 265 Subpart I (CFR, 2005a). These provisions include managing the waste in containers 
compatible with the waste type, and segregating incompatible waste types so that in the event of a spill, leak, or release, incompatible wastes shall not contact one another. The HWAAs will be covered under a site-specific emergency response and contingency action plan until such time that the waste is determined to be nonhazardous or all containers of hazardous waste have been removed from the storage area. Hazardous waste will be characterized in accordance with the requirement of Title 40 CFR 261. Resource Conservation and Recovery Act-“listed” waste has not been identified at CAU 553. Any waste determined to be hazardous will be managed and transported in accordance with RCRA and DOT requirements to a permitted treatment, storage, and disposal facility (CFR, 2005a).

\subsubsection{Hydrocarbon Waste}

Hydrocarbon soil waste containing more than 100 milligrams per kilogram (mg/kg) of TPH will be managed on site in a drum or other appropriate container until fully characterized. Hydrocarbon waste may be disposed of at a designated hydrocarbon landfill (NDEP, 1997b), an appropriate hydrocarbon waste management facility (e.g., recycling facility), or other method in accordance with State of Nevada regulations.

\subsubsection{Mixed Low-Level Waste}

Mixed waste, if generated, shall be managed and dispositioned according to the requirements of RCRA (CFR, 2005a) or subject to agreements between NNSA/NSO and the State of Nevada, as well as DOE requirements for radioactive waste. The waste will be marked with the words "Hazardous Waste Pending Analysis and Radioactive Waste Pending Analysis.” Waste characterized as mixed will not be stored for a period of time that exceeds RCRA requirements unless subject to agreements between NNSA/NSO and the State of Nevada. The mixed waste shall be transported via an approved hazardous waste/radioactive waste transporter to the NTS transuranic waste storage pad for storage pending treatment or disposal. Mixed waste with hazardous waste constituent concentrations below Land Disposal Restrictions may be disposed of at the NTS Area 5 Radioactive Waste Management Site if the waste meets the requirements of the NTSWAC (NNSA/NSO, 2006a), the NTS NDEP permit for a Hazardous Waste Management Facility (NEV HW0009 [NDEP, 2000]), and the RCRA Part B Permit Application for Waste Management Activities at the NTS (DOE/NV, 1999). Mixed waste constituent concentrations exceeding Land Disposal Restrictions will require development of a 
treatment and disposal plan under the requirements of the Mutual Consent Agreement between DOE and the State of Nevada (NDEP, 1995).

\subsubsection{Polychlorinated Biphenyls}

The management of PCBs is governed by the Toxic Substances Control Act (TSCA) (USC, 1976) and its implementing regulations at 40 CFR 761 (CFR, 2005b). Polychlorinated biphenyl contamination may be found as a sole contaminant or in combination with any of the types of waste discussed in this document. For example, PCBs may be a co-contaminant in soil that contains a RCRA “characteristic” waste (PCB/hazardous waste), or in soil that contains radioactive wastes (PCB/radioactive waste), or in mixed waste (PCB/radioactive/hazardous waste). The IDW will be initially evaluated using analytical results for media samples from the investigation. If any type of PCB waste is generated, it will be managed according to 40 CFR 761 (CFR, 2005b) as well as State of Nevada requirements, (NAC, 2004a) guidance, and agreements with NNSA/NSO.

\subsection{Management of Specific Waste Streams}

\subsubsection{Personal Protective Equipment}

Personal protective equipment and disposable sampling equipment will be visually inspected for stains, discoloration, and gross contamination, as the waste is generated; and also evaluated for radiological contamination. Staining and/discoloration will be assumed to be the result of contact with potentially contaminated media such as soil, sludge, or liquid. Gross contamination is the visible contamination of an item (e.g., clumps of soil/sludge on a sampling spoon or free liquid smeared on a glove). While gross contamination can often be removed through decontamination methods, removal of gross contamination from small items, such as gloves or booties is not typically conducted. Any IDW that meets this description will be segregated and managed as potentially "characteristic" hazardous waste. This segregated population of waste will be: (1) assigned the characterization of the soil/sludge that was sampled, (2) sampled directly, or (3) undergo further evaluation using the soil/sludge sample results to determine how much soil/sludge would need to be present in the waste to exceed regulatory levels. Waste that is determined to be hazardous will be entered into an approved waste management system, where it will be managed and dispositioned according to RCRA requirements or subject to agreements between NNSA/NSO and the State of Nevada. The PPE and 
disposable sampling equipment that is not visibly stained, discolored, or grossly contaminated and that is within the radiological free-release criteria will be managed as nonhazardous sanitary waste.

\subsubsection{Management of Decontamination Rinsate}

Rinsate at CAU 553 will not be considered hazardous waste unless there is evidence that the rinsate may display a RCRA characteristic. Evidence may include such things as the presence of a visible sheen, $\mathrm{pH}$, or association with equipment/materials used to respond to a release/spill of a hazardous waste/substance. Decontamination rinsate that is potentially hazardous (using associated sample results and/or process knowledge) will be managed as characteristic hazardous waste (CFR, 2005a). The regulatory status of the potentially hazardous rinsate will be determined through the application of associated sample results or through direct sampling. If the associated samples do not indicate the presence of hazardous constituents, then the rinsate will be considered nonhazardous.

The disposal of nonhazardous rinsate will be consistent with guidance established in current NNSA/NSO Fluid Management Plans for the NTS as follows:

- Rinsate that is determined to be nonhazardous and contaminated to less than 5x Safe Drinking Water Standards (SDWS) is not restricted as to disposal. Nonhazardous rinsate contaminated at 5x to 10x SDWS will be disposed of in an established infiltration basin or solidified and disposed of as sanitary waste or low-level waste in accordance with the respective sections of this document.

- Nonhazardous rinsate contaminated at greater than 10x SDWS will be disposed of in a lined basin or solidified and disposed of as sanitary waste or low-level waste in accordance with the respective sections of this document.

\subsubsection{Management of Soil/Bentonite}

This waste stream consists of soil and/or bentonite waste removed for disposal during soil sampling, excavation, and/or drilling. This waste stream will be characterized based on laboratory analytical results from representative locations or sampled directly. If the soil is determined to potentially contain COCs, the material will either be managed on site or containerized for transportation to an appropriate disposal site. 
On-site management of the potentially hazardous waste soil will be allowed only if it is managed within an area of concern and it is appropriate to defer the management of the waste until the final remediation of the site. If this option is chosen, the waste soil shall be protected from run-on and run-off using appropriate protective measures based on the type of contaminant(s) (e.g., covered with plastic and bermed).

Management of soil waste for disposal consists of placing the waste in containers, labeling the containers, temporarily storing the containers until shipped, and shipping the waste to a disposal site. The containers, labels, management of stored waste, transport to the disposal site, and disposal shall be appropriate for the type of waste (e.g., hazardous, hydrocarbon, mixed).

Note that soils placed back into a borehole or excavation in the same approximate location from which it originated is not considered to be a waste.

\subsubsection{Management of Debris}

This waste stream can vary depending on site conditions. Debris that requires removal for the investigation activities (soil sampling, excavation, and/or drilling) must be characterized for proper management and disposition. Historical site knowledge, waste generation process knowledge, field observations, field-monitoring/screening results, radiological survey/swipe results and/or the analytical results of samples, either directly or indirectly associated with the waste, may be used to characterized the debris. Debris will be visually inspected for stains, discoloration, and gross contamination. Debris may be deemed reusable, recyclable, sanitary waste, hazardous waste, PCB waste, or low-level waste. Waste that is not sanitary will be entered into an approved waste management system, where it will be managed and dispositioned according to requirements and agreements between NNSA/NSO and the State of Nevada. The debris will either be managed on site by berming and covering next to the excavation, placement in a container(s), or left on the footprint of the CAS and its disposition deferred until implementation of corrective action at the site.

\subsubsection{Field-Screening Waste}

The use of field test kits and/or instruments may result in the generation of small quantities of hazardous wastes. If hazardous waste is produced by field screening, it will be segregated from other 
IDW and managed in accordance with the hazardous waste regulations (CFR, 2005a). For sites where field-screening samples contain radioactivity above background levels, field-screening methods that have the potential to generate hazardous waste will not be used, thus avoiding the potential to generate mixed waste. In the event a mixed waste is generated, the waste will be managed in accordance with the requirements in Section 6.2.5. 


\subsection{Quality Assurance/Quality Control}

The overall objective of the characterization activities described in this SAFER Plan is to collect accurate and defensible data to support the selection and implementation of a closure alternative for each CAS in CAU 553. Sections 7.1 and 7.2 discuss the collection of required quality control (QC) samples in the field and quality assurance (QA) requirements for laboratory/analytical data to achieve closure. Unless otherwise stated in this SAFER Plan or required by the results of the DQO process (see Appendix B), this investigation will adhere to the Industrial Sites QAPP (NNSA/NV, 2002a).

\subsection{Sample Collection Activities}

Field QC samples will be collected in accordance with established procedures. Field QC samples are collected and analyzed to aid in determining the validity of environmental sample results. The number of required QC samples depends on the types and number of environmental samples collected. The minimum frequency of collecting and analyzing QC samples for this investigation, as determined in the DQO process, include:

- $\quad$ Trip blanks (1 per sample cooler containing VOC environmental samples)

- Equipment rinsate blanks (1 per sampling event for each type of decontamination procedure)

- Source blanks (1 per lot of source material that contacts sampled media)

- Field duplicates (1 per 20 environmental samples or 1 per CAS per matrix if less than 20)

- Field blanks (1 per 20 environmental samples or 1 per day)

- Laboratory QC samples (1 per 20 environmental samples)

Additional QC samples may be submitted based on site conditions at the discretion of the Task Manager or SS. Field QC samples shall be analyzed using the same analytical procedures implemented for associated environmental samples. Additional details regarding field QC samples are available in the Industrial Sites QAPP (NNSA/NV, 2002a).

\subsection{Applicable Laboratory/Analytical Data Quality Indicators}

The DQIs are qualitative and quantitative descriptors used in interpreting the degree of acceptability or utility of data. Data quality indicators are used to evaluate the entire measurement system and laboratory measurement processes (i.e., analytical method performance) as well as to evaluate 
individual analytical results (i.e., parameter performance). The quality and usability of data used to make DQO decisions will be assessed based on the following DQIs:

- Precision

- Accuracy/bias

- Representativeness

- Comparability

- Completeness

- Sensitivity

Table 7-1 provides the established analytical method/measurement system performance criteria for each of the DQIs and the potential impacts to the decision if the criteria are not met. The following subsections discuss each of the DQIs that will be used to assess the quality of laboratory data. Due to changes in analytical methodology and laboratory contracts, criteria for precision and accuracy in Tables 7-2 and 7-3 that vary from corresponding information in the Industrial Sites QAPP will supersede that information in the Industrial Sites QAPP (NNSA/NV, 2002a).

\subsubsection{Precision}

Precision is a measure of the repeatability of the analysis process from sample collection through analysis results. It is used to assess the variability between two equal samples.

Determinations of precision will be made for laboratory duplicate samples. The laboratory sample duplicates are an aliquot, or subset, of a field sample generated in the laboratory. They are not a separate sample but a split, or portion, of an existing sample. Typically, laboratory duplicate QC samples may include matrix spike duplicate (MSD) and laboratory control sample (LCS) duplicate samples for organic, inorganic, and radiological analyses.

Precision is a quantitative measure used to assess overall analytical method and field-sampling performance as well as to assess the need to "flag" (qualify) individual parameter results when corresponding QC sample results are not within established control limits.

The criteria used for the assessment of chemical precision when both results are greater than or equal to $5 x$ reporting limit (RL) is 20 percent and 35 percent for aqueous and soil samples, respectively. 
Table 7-1

Laboratory and Analytical Performance Criteria for CAU 553 DQIs

\begin{tabular}{|c|c|c|}
\hline $\begin{array}{l}\text { Data Quality } \\
\text { Indicator }\end{array}$ & Performance Metric & $\begin{array}{l}\text { Potential Impact on Decision } \\
\text { If Performance Metric Not Met }\end{array}$ \\
\hline Precision & $\begin{array}{l}\text { At least } 80 \% \text { of the sample results for each } \\
\text { measured contaminant are not qualified for } \\
\text { precision based on the criteria for each analytical } \\
\text { method-specific and laboratory-specific criteria } \\
\text { presented in Tables } 7-2 \text { and } 7-3 \text {. }\end{array}$ & $\begin{array}{l}\text { If the performance metric is not met, the } \\
\text { affected analytical results from each } \\
\text { affected CAS will be assessed to determine } \\
\text { whether there is sufficient confidence in } \\
\text { analytical results to use the data in making } \\
\text { DQO decisions. }\end{array}$ \\
\hline Accuracy & $\begin{array}{l}\text { At least } 80 \% \text { of the sample results for each } \\
\text { measured contaminant are not qualified for } \\
\text { accuracy based on the method-specific and } \\
\text { laboratory-specific criteria presented in } \\
\text { Tables } 7-2 \text { and } 7-3 \text {. }\end{array}$ & $\begin{array}{l}\text { If the performance metric is not met, the } \\
\text { affected analytical results from each } \\
\text { affected CAS will be assessed to determine } \\
\text { whether there is sufficient confidence in } \\
\text { analytical results to use the data in making } \\
\text { DQO decisions. }\end{array}$ \\
\hline Sensitivity & $\begin{array}{l}\text { Minimum detectable concentrations are less than } \\
\text { or equal to respective FALs. }\end{array}$ & $\begin{array}{l}\text { Cannot determine whether COCs are } \\
\text { present or migrating at levels of concern. }\end{array}$ \\
\hline Comparability & $\begin{array}{l}\text { Sampling, handling, preparation, analysis, } \\
\text { reporting, and data validation are performed } \\
\text { using standard methods and procedures. }\end{array}$ & $\begin{array}{l}\text { Inability to combine data with data obtained } \\
\text { from other sources and/or inability to } \\
\text { compare data to regulatory action levels. }\end{array}$ \\
\hline Representativeness & $\begin{array}{l}\text { Samples contain contaminants at concentrations } \\
\text { present in the environmental media from which } \\
\text { they were collected. }\end{array}$ & $\begin{array}{l}\text { Analytical results will not represent true site } \\
\text { conditions. Inability to make appropriate } \\
\text { DQO decisions. }\end{array}$ \\
\hline Completeness $^{\mathrm{a}}$ & $\begin{array}{l}80 \% \text { of the CAS-specific COPCs have valid } \\
\text { results. }\end{array}$ & $\begin{array}{l}\text { Cannot support/defend decision on whether } \\
\text { COCs are present. }\end{array}$ \\
\hline Extent Completeness & $\begin{array}{l}100 \% \text { of COCs used to define extent have valid } \\
\text { results. }\end{array}$ & $\begin{array}{l}\text { Extent of contamination cannot be } \\
\text { accurately determined. }\end{array}$ \\
\hline $\begin{array}{l}\text { Clean Closure } \\
\text { Completeness }^{\mathrm{a}}\end{array}$ & $100 \%$ of COCs have valid results. & $\begin{array}{l}\text { Cannot determine whether COCs remain in } \\
\text { soil. }\end{array}$ \\
\hline
\end{tabular}

${ }^{\mathrm{a}}$ No targeted COPCs for this investigation.

CAS $=$ Corrective action site

$\mathrm{COC}=$ Contaminant of concern

COPC = Contaminant of potential concern
$\mathrm{DQI}=$ Data quality indicator

$\mathrm{DQO}=$ Data quality objective

$\mathrm{FAL}=$ Final action level

When either result is less than $5 x$ RL, a control limit of $\pm 1 x$ RL and $\pm 2 x$ RL for aqueous and soil samples, respectively, is applied to the absolute difference.

The criteria used for the assessment of radiological precision when both results are greater than or equal to $5 \mathrm{x}$ MDC is 20 percent and 35 percent for aqueous and soil samples, respectively. When either result is less than $5 x$ MDC, the normalized difference should be between -2 and +2 for aqueous and soil samples. 
Table 7-2

Analytical Requirements for Radionuclides for CAU 553

(Page 1 of 2)

\begin{tabular}{|c|c|c|c|c|c|c|}
\hline ParameterIAnalyte & Matrix & $\begin{array}{l}\text { Analytical } \\
\text { Method }\end{array}$ & $\mathrm{MDC}^{\mathrm{a}}$ & $\mathrm{PAL}^{\mathrm{b}, \mathrm{c}}$ & $\begin{array}{c}\text { Laboratory } \\
\text { Precision (RPD) }\end{array}$ & $\begin{array}{c}\text { Percent Recovery } \\
\text { (\%R) }\end{array}$ \\
\hline \multicolumn{7}{|c|}{ Gamma Spectroscopy } \\
\hline Americium-241 & Soil & HASL-300 ${ }^{d}$ & $2.0 \mathrm{pCi} / \mathrm{g}^{\mathrm{e}}$ & $12.7 \mathrm{pCi} / \mathrm{g}$ & \multirow{3}{*}{$\begin{array}{c}\text { Relative Percent } \\
\text { Difference (RPD) } 35 \% \\
\text { Normalized Difference } \\
\quad-2<N D<2^{\dagger}\end{array}$} & \multirow{3}{*}{$\begin{array}{l}\text { Laboratory Control } \\
\text { Sample Recovery } \\
80-120^{9} \text { Percent } \\
\text { Recovery }(\% \mathrm{R})\end{array}$} \\
\hline Cesium-137 & Soil & HASL-300 & $0.5 \mathrm{pCi} / \mathrm{g}^{\mathrm{e}}$ & $12.2 \mathrm{pCi} / \mathrm{g}$ & & \\
\hline Cobalt-60 & Soil & HASL-300 ${ }^{d}$ & $0.5 \mathrm{pCi} / \mathrm{g}^{\mathrm{e}}$ & $2.68 \mathrm{pCi} / \mathrm{g}$ & & \\
\hline \multicolumn{7}{|c|}{ Other Radionuclides } \\
\hline Plutonium-238 & Soil & ASTM C 1001-00 & $0.05 \mathrm{pCi} / \mathrm{g}$ & $13.0 \mathrm{pCi} / \mathrm{g}$ & \multirow{6}{*}{$\begin{array}{c}\text { Relative Percent } \\
\text { Difference (RPD) 35\% } \\
\begin{array}{c}\text { Normalized Difference } \\
-2<\mathrm{ND}<2^{\dagger}\end{array}\end{array}$} & \multirow{6}{*}{$\begin{array}{l}\text { Laboratory Control } \\
\text { Sample Recovery } \\
80-120^{9} \text { Percent } \\
\text { Recovery (\%R) } \\
\text { Chemical Yield } \\
\text { 30-105' \%R } \\
\text { (not applicable for } \\
\text { tritium) }\end{array}$} \\
\hline Plutonium-239/240 & Soil & ASTM C 1001-00 & $0.05 \mathrm{pCi} / \mathrm{g}$ & $12.7 \mathrm{pCi} / \mathrm{g}$ & & \\
\hline Strontium-90 & Soil & HASL $300^{d}$ & $0.5 \mathrm{pCi} / \mathrm{g}$ & $838 \mathrm{pCi} / \mathrm{g}$ & & \\
\hline Uranium-234 & Soil & ASTM C 1000-02 & $0.05 \mathrm{pCi} / \mathrm{g}$ & $143 \mathrm{pCi} / \mathrm{g}$ & & \\
\hline Uranium-235 & Soil & ASTM $^{j}$ & $0.05 \mathrm{pCi} / \mathrm{g}$ & $17.6 \mathrm{pCi} / \mathrm{g}$ & & \\
\hline Uranium-238 & Soil & ASTM C 1000-02 & $0.05 \mathrm{pCi} / \mathrm{g}$ & $105 \mathrm{pCi} / \mathrm{g}$ & & \\
\hline
\end{tabular}


Table 7-2

Analytical Requirements for Radionuclides for CAU 553

(Page 2 of 2)

\begin{tabular}{|c|c|c|c|c|c|c|}
\hline Parameter/Analyte & Matrix & $\begin{array}{l}\text { Analytical } \\
\text { Method }\end{array}$ & $\mathrm{MDC}^{\mathrm{a}}$ & $\mathbf{P A L}^{\mathrm{b}, \mathrm{c}}$ & $\begin{array}{c}\text { Laboratory } \\
\text { Precision (RPD) }\end{array}$ & $\begin{array}{c}\text { Percent Recovery } \\
(\% R)\end{array}$ \\
\hline
\end{tabular}

${ }^{2}$ The MDC is the lowest concentration of a radionuclide, if present in a sample, that can be detected with a 95 percent confidence level.

${ }^{\mathrm{b}}$ The PALs for soil are based on the National Council for Radiation Protection and Measurement (NCRP) Report No. 129 Recommended Screening Limits for Contaminated Soil and Review of Factors Relevant to Site-Specific Studies (NCRP, 1999) scaled to $25 \mathrm{mrem} / \mathrm{yr}$ dose and the guidelines for residual concentration of radionuclides in DOE Order 5400.5 (DOE, 1993).

${ }^{\mathrm{c} P A L s}$ for liquids will be developed as needed.

${ }^{\mathrm{d}}$ The Procedures Manual of the Environmental Measurements Laboratory, HASL-300 (DOE, 1997).

${ }^{\mathrm{e}} \mathrm{MDC}$ s vary depending on the presence of other gamma-emitting radionuclides in the sample and are relative to the MDC for cesium-137.

${ }^{f} \mathrm{ND}$ is not RPD, it is another measure of precision used to evaluate duplicate analyses. The ND is calculated as the difference between two results divided by the square root of the sum of the squares of their total propagated uncertainties. Evaluation of Radiochemical Data Usability (Paar and Porterfield, 1997).

'EPA Contract Laboratory Program Statement of Work for Inorganic Analysis (EPA, 1988; 1994; and 1995).

${ }^{\mathrm{h}}$ Standard Test Method for Radiochemical Determination of Plutonium in Soil by Alpha Spectroscopy (ASTM, 2002).

'General Radiochemistry and Routine Analytical Services Protocol (GRASP) (EG\&G Rocky Flats, 1991). The chemical yield only applies to plutonium, uranium, and strontium.

iStandard Test Method for Radiochemical Determination of Uranium Isotopes in Soil by Alpha Spectrometry (ASTM, 2000).

ASTM $=$ American Society for Testing and Materials

$E P A=U . S$. Environmental Protection Agency

HASL = Health and Safety Laboratory

MDC $=$ Minimum detectable concentration

$\mathrm{mrem} / \mathrm{yr}=$ Millirem per year

ND $=$ Normalized difference

$\mathrm{PAL}=$ Preliminary action level

$\mathrm{pCi} / \mathrm{g}=$ Picocuries per gram

$\mathrm{pCi} / \mathrm{L}=$ Picocuries per liter

UGTA = Underground Test Area 
Table 7-3

Analytical Requirements for Chemical COPCs for CAU 553

\begin{tabular}{|c|c|c|c|c|c|}
\hline Parameter/Analyte & $\begin{array}{l}\text { Medium or } \\
\text { Matrix }\end{array}$ & $\begin{array}{l}\text { Analytical } \\
\text { Method }\end{array}$ & $\begin{array}{l}\text { Minimum Detectable } \\
\text { Concentration } \\
\text { (MDC) }\end{array}$ & $\begin{array}{l}\text { Laboratory } \\
\text { Precision } \\
\text { (RPD) }^{\mathrm{a}}\end{array}$ & $\begin{array}{c}\text { Percent } \\
\text { Recovery }(\% R)^{\mathrm{b}}\end{array}$ \\
\hline \multicolumn{6}{|c|}{ ORGANICS } \\
\hline Total Volatile Organic Compounds & Soil & $8260 B^{c}$ & Parameter-specific EQLs $^{d}$ & Lab-specific $^{\mathrm{e}}$ & Lab-specific $^{\mathrm{e}}$ \\
\hline Total Semivolatile Organic Compounds & Soil & $8270 C^{c}$ & Parameter-specific EQLs ${ }^{d}$ & Lab-specific $^{\mathrm{e}}$ & Lab-specific $^{\mathrm{e}}$ \\
\hline $\begin{array}{l}\text { Total Petroleum Hydrocarbons- } \\
\text { Diesel-Range Organics }\end{array}$ & Soil & $\begin{array}{l}\text { 8015B } \\
\text { modified }^{\mathrm{c}}\end{array}$ & $25 \mathrm{mg} / \mathrm{kg}^{\dagger}$ & Lab-specific $^{\mathrm{e}}$ & Lab-specific ${ }^{e}$ \\
\hline
\end{tabular}

See Table 7-2 for the analytical requirements for radionuclides.

aprecision is estimated from the RPD of the laboratory or field duplicates MSD and LCSD are spiked. It is calculated by: RPD $=100 \times\left(\left|A_{1}-A_{2}\right|\right) /\left[\left(A_{1}+A_{2}\right) / 2\right]$ where $A_{1}=$ Concentration of the parameter in the initial sample aliquot, $A_{2}=$ Concentration of the parameter in the duplicate sample aliquot.

${ }^{\mathrm{b}} \mathrm{Accuracy}$ is assessed from the $\% \mathrm{R}$ of parameters spiked into a blank or sample matrix of interest, or from the recovery of surrogate compounds spiked into each sample. The recovery of each spiked parameter is calculated by: $\% R=100 \times\left(A_{s}-A_{u} / A_{n}\right)$, where

$A_{s}=$ Concentration of the parameter in the spiked sample, $A_{u}=$ Concentration of the parameter in the unspiked sample,

$A_{n}=$ Concentration increase that should result from spiking the sample.

'EPA Test Methods for Evaluating Solid Waste Physical/Chemical Methods, 3rd Edition, Parts 1-4, (SW-846) CD-ROM, Washington, DC (EPA,1996)

dEQL as given in SW-846 (EPA, 1996)

${ }^{e} \mathrm{RPD}$ and \%R Performance Criteria are developed and generated in-house by the laboratory according to approved laboratory procedures.

fIndustrial Sites Quality Assurance Project Plan (NNSA/NV, 2002a).

EPA $=$ U.S. Environmental Protection Agency

$\mathrm{EQL}=$ Estimated quantitation limit

LCSD = Laboratory control sample duplicate

$\mathrm{mg} / \mathrm{kg}=$ Milligrams per kilogram

$\mathrm{MSD}=$ Matrix spike duplicate

$\mathrm{RPD}=$ Relative percent difference 
Any values outside the specified criteria do not necessarily result in the qualification of analytical data. It is only one factor in making an overall judgment about the quality of the reported analytical results. The performance metric for assessing the DQI of precision on DQO decisions (Table 7-1) is that at least 80 percent of sample results for each measured contaminant are not qualified due to duplicates exceeding the criteria. If this performance is not met, an assessment will be conducted in the Closure Report on the impacts to DQO decisions specific to affected contaminants and CASs.

\subsubsection{Accuracy/Bias}

Accuracy is a measure of the closeness of an individual measurement to the true value. It is used to assess the performance of laboratory measurement processes.

Accuracy is determined by analyzing a reference material of known parameter concentration or by re-analyzing a sample to which a material of known concentration or amount of parameter has been added (spiked). Accuracy will be evaluated based on results from three types of spiked samples: matrix spike (MS), LCS, and surrogates (organics). The LCS sample is analyzed with the field samples using the same sample preparation, reagents, and analytical methods employed for the samples. One LCS will be prepared with each batch of samples for analysis by a specific measurement.

The criteria used for the assessment of organic chemical accuracy are developed and generated by the laboratory according to approved laboratory procedures. The criteria used for the assessment of radiochemical accuracy are 80 to 120 percent for LCS and MS recoveries.

Any values outside the specified criteria do not necessarily result in the qualification of analytical data. It is only one factor in making an overall judgment about the quality of the reported analytical results. Factors beyond laboratory control, such as sample matrix effects, can cause the measured values to be outside of the established criteria. Therefore, the entire sampling and analytical process may be evaluated when determining the usability of the affected data.

The performance metric for assessing the DQI of accuracy on DQO decisions (Table 7-1) is that at least 80 percent of the sample results for each measured contaminant are not qualified for accuracy. 
If this performance is not met, an assessment will be conducted in the Closure Report on the impacts to DQO decisions specific to affected contaminants and CASs.

\subsubsection{Representativeness}

Representativeness is the degree to which sample characteristics accurately and precisely represent a characteristics of a population or an environmental condition (EPA, 1987). Representativeness is assured by carefully developing the sampling strategy during the DQO process such that false negative and false positive decision errors are minimized. The criteria listed in DQO Step 6 - Specify Performance or Acceptance Criteria are:

- For Decision I judgmental sampling, having a high degree of confidence that the sample locations selected will identify COCs if present anywhere within the CAS.

- Having a high degree of confidence that analyses conducted will be sufficient to detect any COCs present in the samples.

- For Decision II, having a high degree of confidence that the sample locations selected will identify the extent of COCs.

These are qualitative measures that will be used to assess measurement system performance for representativeness. The assessment of this qualitative criterion will be presented in the Closure Report.

\subsubsection{Comparability}

Comparability is a qualitative parameter expressing the confidence with which one dataset can be compared to another (EPA, 1987). The criteria for the evaluation of comparability will be that all sampling, handling, preparation, analysis, reporting, and data validation were performed using approved standard methods and procedures. This will ensure that data from this project can be compared to regulatory action levels that were developed based on data generated using the same or comparable methods and procedures. An evaluation of comparability will be presented in the Closure Report. 


\subsubsection{Completeness}

Completeness is defined as generating sufficient data of the appropriate quality to satisfy the data needs identified in the DQOs. For judgmental sampling, completeness will be evaluated using both a quantitative measure and a qualitative assessment. The quantitative measurement to be used to evaluate completeness is presented in Table 7-1 and is based on the percentage of measurements made that are judged to be valid. For the judgmental sampling approach, the completeness goal for COPCs is 80 percent; there are no targeted contaminants for this investigation. If this goal is not achieved, the dataset will be assessed for potential impacts on making DQO decisions.

The qualitative assessment of completeness is an evaluation of the sufficiency of information available to make DQO decisions. This assessment will be based on meeting the data needs identified in the DQOs and will be presented in the Closure Report. Additional samples will be collected if it is determined that the number of samples do not meet completeness criteria.

\subsubsection{Sensitivity}

Sensitivity is the capability of a method or instrument to discriminate between measurement responses representing different levels of the variable of interest (EPA, 2001). The evaluation criteria for this parameter will be that measurement sensitivity (detection limits) will be less than or equal to the corresponding FALs. If this criterion is not achieved, the affected data will be assessed for usability and potential impacts on meeting site characterization objectives. This assessment will be presented in the Closure Report. 


\subsection{References}

ASTM, see American Society for Testing and Materials.

Alderson, S., IT Corporation. 2002. Memorandum to R. Bull (SAIC) entitled, "Radiological Land Surveys of 24 Corrective Action Sites (CASs) at the Nevada Test Site.” 26 August.

Las Vegas, NV.

American Society for Testing and Materials. 1995. Standard Guide for Risk-Based Corrective Action Applied at Petroleum Release Sites/American Society for Testing and Materials, ASTM E 1739-95 (Reapproved 2002). Philadelphia, PA.

American Society for Testing and Materials. 2000. Standard Test Method for Radiochemical Determination of Uranium Isotopes in Soil by Alpha Spectrometry, ASTM C 1000-00. West Conshohocken, PA: ASTM International.

American Society for Testing and Materials. 2002. Standard Test Method for Radiochemical Determination of Plutonium in Soil by Alpha Spectroscopy, ASTM C 1001-00.

West Conshohocken, PA: ASTM International.

BN, see Bechtel Nevada.

Bechtel Nevada. 1995. Nevada Test Site Performance Objective for Certification of Nonradioactive Hazardous Waste, Rev. 0, G-E11/96.01. Las Vegas, NV.

CFR, see Code of Federal Regulations.

Code of Federal Regulations. 2005a. Title 40 CFR, Parts 260-282, "Hazardous Waste Management System: General.” Washington, DC: U.S. Government Printing Office.

Code of Federal Regulations. 2005b. Title 40 CFR, Parts 761, "Polychlorinated Biphenyls (PCBs) Manufacturing, Processing, Distribution in Commerce, and Use Prohibitions.” Washington, DC: U.S. Government Printing Office.

Code of Federal Regulations. 2005c. Title 40 CFR, Part 763, “Asbestos.” Washington, DC:

U.S. Government Printing Office.

DOE, see U.S. Department of Energy.

DOE/NV, see U.S. Department of Energy, Nevada Operations Office.

EPA, see U.S. Environmental Protection Agency. 
EG\&G Rocky Flats. 1991. General Radiochemistry and Routine Analytical Services Protocol (GRASP), Version 2.1, July. Golden, CO: Environmental Management Department.

FFACO, see Federal Facility Agreement and Consent Order.

Fahringer, P., Stoller-Navarro Joint Venture. 2006. Memorandum to J. Myers (SNJV) entitled, “CAU 545, CAS 03-17-01 and CAU 553, CAS 19-99-01 - Memorandum of Findings,” April. Las Vegas, NV.

Federal Facility Agreement and Consent Order. 1996 (as amended). Agreed to by the State of Nevada, the U.S. Department of Energy, and the U.S. Department of Defense.

Geary, D. 1965. Letter to R.C. Emens (AEC) regarding the Pahute Mesa Mud Mixing Plant, 29 January. Las Vegas, NV.

Murphy, T., Bureau of Federal Facilities. 2004. Letter to R. Bangerter (NNSA/NSO) entitled, "Review of Industrial Sites Project Document Guidance for Calculating Industrial Sites Project Remediation Goals for Radionuclides in Soil Using the Residual Radiation (RESRAD) Computer Code.” 19 November. Las Vegas, NV.

NAC, see Nevada Administrative Code.

NCRP, see National Council on Radiation Protection and Measurements.

NDEP, see Nevada Division of Environmental Protection.

NNSA/NSO, see U.S. Department of Energy, National Nuclear Security Administration Nevada Site Office.

NNSA/NV, see U.S. Department of Energy, National Nuclear Security Administration Nevada Operations Office.

NRS, see Nevada Revised Statutes.

National Council on Radiation Protection and Measurements. 1999. Recommended Screening Limits for Contaminated Surface Soil and Review of Factors Relevant to Site-Specific Studies/National Council on Radiation Protection and Measurements, NCRP Report No. 129. Bethesda, MD.

Nevada Administrative Code. 2004a. NAC 444, “Sanitation.” Carson City, NV. As accessed at http://www.leg.state.nv.us/nac on 12 September 2006.

Nevada Administrative Code. 2004b. NAC 445A, "Water Controls.” Carson City, NV. As accessed at http://www.leg.state.nv.us/nac on 12 September 2006. 
Nevada Administrative Code. 2005. NAC 445A.2272, "Contamination of Soil: Establishment of Action Levels.” Carson City, NV. As accessed at http://www.leg.state.nv.us/nac on 12 September 2006.

Nevada Division of Environmental Protection. 1995. Mutual Consent Agreement between the State of Nevada and the U.S. Department of Energy for the Storage of Low-Level Land Disposal Restricted Mixed Waste. Carson City, NV.

Nevada Division of Environmental Protection. 1997a. Class II Solid Waste Disposal Site for Municipal and Solid Waste, Area 23 of the NTS, Permit SW 13-097-04. Carson City, NV.

Nevada Division of Environmental Protection. 1997b (as amended in August 2000). Class III Solid Waste Disposal Site for Hydrocarbon Burdened Soils, Area 6 of the NTS, Permit SW 13-097-02. Carson City, NV.

Nevada Division of Environmental Protection. 1997c (as amended in August 2000). Class III Solid Waste Disposal Site; UIOC, Area 9 of the NTS, Permit SW 13-097-03. Carson City, NV.

Nevada Division of Environmental Protection. 1999. State of Nevada Water Pollution Control General Permit, No. GNEV93001. Carson City, NV.

Nevada Division of Environmental Protection. 2000. Hazardous Waste Management Facility Draft Permit, No. NEV HW009. Carson City, NV.

Nevada Revised Statutes. 2005a. NRS 444.440 - 444.620, “Collection and Disposal of Solid Waste.” Carson City, NV.

Nevada Revised Statutes. 2005b. NRS 459.400 - 459.600, “Disposal of Hazardous Waste.” Carson City, NV.

Nevada Revised Statutes. 2005c. NRS 618.750 - 618.840, “Disposal of Hazardous Waste.” Carson City, NV.

Paar, J.G., and D.R. Porterfield. 1997. Evaluation of Radiochemical Data Usability, ES/ER/MS-5. April. Oak Ridge, TN: U.S. Department of Energy.

REECo, see Reynolds Electrical \& Engineering Co., Inc.

RSN, see Raytheon Services Nevada.

Raytheon Services Nevada. 1991. Nevada Test Site Drilling and Mining Summary. Prepared for the U.S. Department of Energy, Nevada Operations Office. Las Vegas, NV. 
Reynolds Electrical \& Engineering Co., Inc. 1991. Nevada Test Site Inventory of Inactive and Abandoned Facilities and Waste Sites, Areas 16-20, Volume 4 of 5, DOE/NV 10630-18. April. Las Vegas, NV.

Reynolds Electrical \& Engineering Co., Inc. 1992. RCRA Part B Permit Application for Waste Management Activities at the Nevada Test Site: Section L, Potential Solid Waste Management Units. Nevada Test Site, NV.

Reynolds Electrical \& Engineering Co., Inc. 1994. Area 3 Waste Mud Impoundment - Historical Information. Prepared by C.G. Postle. Las Vegas, NV.

SNJV, see Stoller-Navarro Joint Venture.

Shaw, see Shaw Environmental, Inc.

Shaw Environmental, Inc. 2002. Results of Geophysical Survey Selected FFACO Sites Nevada Test Site, Nye County, Nevada, August. Las Vegas, NV.

Stoller-Navarro Joint Venture. 2006. Radiological Land Area Survey, CAU 553 - Areas 19, 20 Mud Pits and Cellars, at the Nevada Test Site. Las Vegas, NV.

USC, see United State Code.

United States Code. 1976. 15 USC 2601 et seq., “Toxic Substances Control Act.” Enacted by Public Law No. 94-469, as amended. Washington, DC: U.S. Government Printing Office.

U.S. Department of Energy. 1993. Radiation Protection of the Public and the Environment, DOE Order 5400.5, Change 2. Washington, DC: U.S. Government Printing Office.

U.S. Department of Energy. 1997. The Procedures Manual of the Environmental Measurements Laboratory, HASL-300, 28th Ed., Vol. I. New York, NY.

U.S. Department of Energy, National Nuclear Security Administration Nevada Operations Office. 2002a. Industrial Sites Quality Assurance Project Plan, Nevada Test Site, Nevada, Rev. 3, DOE/NV—372. Las Vegas, NV.

U.S. Department of Energy, National Nuclear Security Administration Nevada Operations Office. 2002b. Underground Test Area Project Waste Management Plan, Rev. 2, DOE/NV—343. Las Vegas, NV.

U.S. Department of Energy, National Nuclear Security Administration Nevada Site Office. 2004a. Mud Pit Risk-Based Closure Strategy Report, Nevada Test Site, Nevada, DOE/NV—991. Las Vegas, NV. 
U.S. Department of Energy, National Nuclear Security Administration Nevada Site Office. 2004b. NV/YMP Radiological Control Manual, Rev. 5, DOE/NV/11718-079, UC-702. Prepared by A.L. Gile of Bechtel Nevada. Las Vegas, NV.

U.S. Department of Energy, National Nuclear Security Administration Nevada Site Office. 2006a. Closure Report for Corrective Action Units 530, 531, 532, 533, 534, 535: NTS Mud Pits, Nevada Test Site, Nevada, DOE/NV-1131. July. Las Vegas, NV.

U.S. Department of Energy, National Nuclear Security Administration Nevada Site Office. 2006b. Industrial Sites Project Establishment of Final Action Levels. February. Las Vegas, NV.

U.S. Department of Energy, National Nuclear Security Administration Nevada Site Office. 2006c. Nevada Test Site Waste Acceptance Criteria, DOE/NV—325, Rev. 6-01. Las Vegas, NV.

U.S. Department of Energy, Nevada Operations Office. 1996. Final Environmental Impact Statement for the Nevada Test Site and Off-Site Locations in the State of Nevada, DOE/EIS 0243. Las Vegas, NV.

U.S. Department of Energy, Nevada Operations Office. 1998. Nevada Test Site Resource Management Plan. DOE/NV—518, Las Vegas, NV.

U.S. Department of Energy, Nevada Operations Office. 1999. RCRA Part B Permit (NEV HW0021) Application for Waste Management Activities at the Nevada Test Site. Las Vegas, NV.

U.S. Department of Energy, Nevada Operations Office. 2000. United States Nuclear Tests, July 1945 Through September 1992, DOE/NV-209 (Rev. 15). Las Vegas, NV.

U.S. Department of Energy, Nevada Operations Office. 2001. Mud Pit Strategy, Nevada Test Site, Nevada, DOE/NV-684. Las Vegas, NV.

U.S. Environmental Protection Agency. 1987. Data Quality Objectives for Remedial Response Activities, EPA/540/G-87/003. Washington, DC.

U.S. Environmental Protection Agency. 1988. Contract Laboratory Program Statement of Work for Inorganic Analysis, SOW No. 788, EPA/540/R-94/093. Washington, DC.

U.S. Environmental Protection Agency. 1994. Contract Laboratory Program National Functional Guidelines for Inorganic Data Review, EPA/540/R-94/013. Washington, DC.

U.S. Environmental Protection Agency. 1995. Contract Laboratory Program Statement of Work for Inorganic Analysis, ILMO 4.0, EPA/540/R-95/121. Washington, DC.

U.S. Environmental Protection Agency. 1996. Test Method for Evaluating Solid Waste Physical/Chemical Methods, SW-846, 3rd Edition. Washington, DC. 
U.S. Environmental Protection Agency. 2001. Guidance on Data Quality Indicators, EPA QA/G-5i. Washington, DC.

U.S. Environmental Protection Agency. 2004. Region 9 Preliminary Remediation Goals (PRGs). As accessed at http://www.epa.gov/region09/waste/sfund/prg/index.htm on 12 September 2006. Prepared by S.J. Smucker. San Francisco, CA.

U.S. Environmental Protection Agency. 2006. Systematic Planning: A Case Study for Hazardous Waste Site Investigations, EPA QA/CS-1. Washington, DC. 


\section{Appendix A}

\section{Project Organization}




\section{A.1.0 Project Organization}

The NNSA/NSO Federal Sub-Project Director is Kevin Cabble, who can be reached at (702) 295-5000. The NNSA/NSO Task Manager is Sabine Curtis, who can be reached at (702) 295-0542.

The identification of the project Health and Safety Officer and the Quality Assurance Officer can be found in the appropriate plan. However, personnel are subject to change, and it is suggested that the NNSA/NSO Project Manager be contacted for further information. The Task Manager will be identified in the FFACO Monthly Activity Report before the start of field activities. 


\section{Appendix B}

\section{Data Quality Objectives Process}




\section{B.1.0 Introduction}

The DQO process described in this appendix is a seven-step, systematic planning process based on the scientific method used to plan data collection activities and define performance criteria for the CAU 553, Mud Pits and Cellars, field investigation. The DQOs are designed to ensure that the data collected will provide sufficient and reliable information to determine the appropriate corrective actions, verify the adequacy of existing information, provide sufficient data to implement the corrective actions, and verify that closure was achieved.

The CAU 553 investigation will be based on the DQOs presented in this appendix as developed by representatives of NDEP and NNSA/NSO. The seven steps of the DQO process presented in Sections B.3.0 through B.9.0 were developed in accordance with EPA Guidance on Systematic Planning Using the Data Quality Objectives Process (EPA QA/G-4) (EPA, 2006).

In general, the procedures used in the DQO process provide:

- A method to establish performance or acceptance criteria, which serve as the basis for designing a plan for collecting data of sufficient quality and quantity to support the goals of a study.

- Criteria that will be used to establish the final data collection design such as:

- the nature of the problem that has initiated the study and a conceptual model of the environmental hazard to be investigated.

- the decisions or estimates that need to be made and the order of priority for resolving them.

- the type of data needed.

- an analytic approach or decision rule that defines the logic for how the data will be used to draw conclusions from the study findings.

- Acceptable quantitative criteria on the quality and quantity of the data to be collected, relative to the ultimate use of the data.

- A data collection design that will generate data meeting the quantitative and qualitative criteria specified. A data collection design specifies the type, number, location, and physical quantity of samples and data, as well as the QA and QC activities that will ensure that sampling design and measurement errors are managed sufficiently to meet the performance or acceptance criteria specified in the DQOs. 


\section{B.2.0 Background Information}

The following four CASs that comprise CAU 553 are located in NTS Areas 19 and 20, as shown in Figure B.2-1:

- CAS 19-99-01, Mud Spill

- CAS 19-99-11, Mud Spill

- CAS 20-09-09, Mud Spill

- CAS 20-99-03, Mud Spill

The following sections provide a CAS description, physical setting and operational history, release information, and previous investigation results for each CAS. The COPCs identified for the mud spills in CAU 553 have been determined based on historical knowledge and previous investigation results conducted under the Mud Pit Risk-Based Closure Strategy Report (NNSA/NSO, 2004a) and the CAU 530-535 Closure Report (NNSA/NSO, 2006a). Both of these reports describe the operational drilling processes conducted at the NTS associated with nuclear testing. The CAU 553 mud spills are assumed to be a result of similar operational processes as the NTS mud pits as well as similarly compositional for mud and additive contents.

\section{B.2.1 CAS 19-99-01, Mud Spill}

Corrective Action Site 19-99-01 consists of the environmental release associated with a mud spill located on and surrounding a dirt mound located north and adjacent to the fenced U-19ad potential crater area (REECo, 1991).

Physical Setting - CAS 19-99-01 is located in Area 19 adjacent to the north side of the fenced U-19ad potential crater area east of Pahute Mesa Road. The mud spill is located on top of a dirt mound and the spill extends downslope in several directions with a small portion extending past the U-19ad fence line. The dirt mound is approximately $8 \mathrm{ft}$ high and covers an area of approximately 1,250 $\mathrm{ft}^{2}$. Scattered vegetation is growing on and around the dirt mound and within the mud. Several pieces of debris are visible within the area and the ground surface has been disturbed and mounded in several locations. Surface soil, including the mound, consists of light-brown to pinkish-brown, silt-to sandsize volcanic material. The thickness of alluvium in the area is unknown; however, the U-19ad emplacement hole penetrated 4,392 ft of alluvium (NNSA/NSO, 2004b). The nearest 


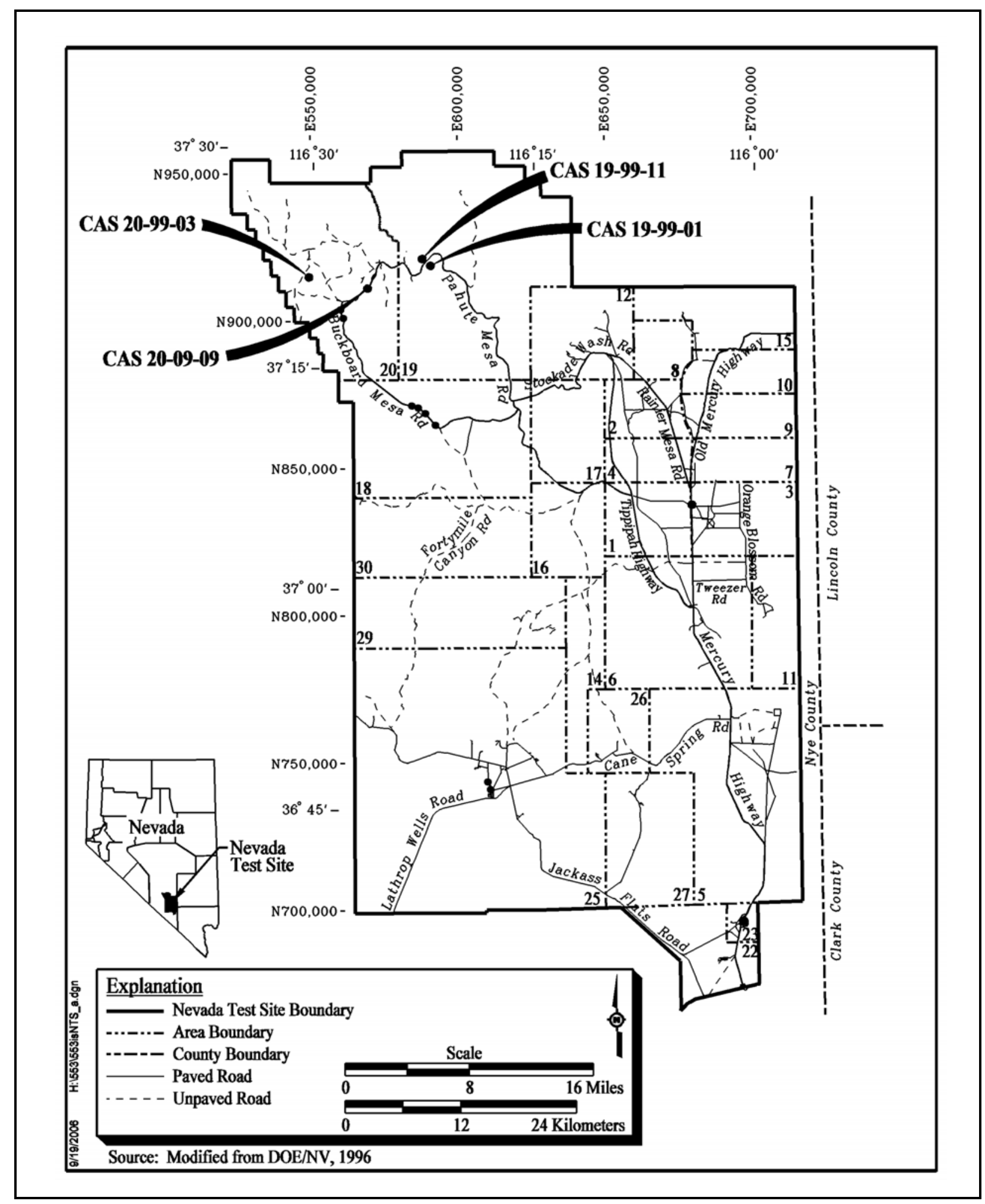

Figure B.2-1

Nevada Test Site Map with CAU 553 CAS Locations 
U.S. Geological Survey (USGS) monitoring well to this CAS is Water Well U-19bk at about $1.9 \mathrm{mi}$ northwest of the CAS and has a depth to groundwater of 2,198 ft bgs (USGS/DOE, 2006b). The nearest water use well is inactive and located about $2.0 \mathrm{mi}$ southeast of the CAS (USGS/DOE, 2006c).

Operational History - The area was used for conducting an underground weapons-related test at U-19ad. The LANL Chancellor test was conducted on September 1, 1983, as a part of Operational Phalanx (DOE/NV, 2000). Based on proximity, CAS 19-99-01 mud spill is believed to be associated with pre- and/or post-test drilling activities at U-19ad; however, several other tests were conducted in the vicinity of the mud spill and drilling activities at these tests may have contributed to the release of drilling mud. Therefore, the mud spill release is assumed to be similar in operation and composition to NTS mud pit material (DOE/NV, 2001).

Release Information - An environmental release associated with drilling activities occurred adjacent to the U-19ad potential crater area. The release may contain TPH and potentially radioactive constituents based on process knowledge of mud pits and drilling processes.

Previous Investigation Results - Geophysical surveys were conducted in 2002 (Shaw) and 2006 (Fahringer) and identified one anomaly to the west of the mound, most likely due to corrugated metal casing partially visible at the surface. No other buried metal was detected below the soil mound. A radiological survey conducted at the site identified elevated gamma readings in the southeast corner of the site; however, it was determined that the site poses no risk to human health from residual radiological contamination (Alderson, 2002). No soil analytical results were identified for this CAS.

\section{B.2.2 CAS 19-99-11, Mud Spill}

Corrective Action Site 19-99-11 consists of the environmental releases associated with three mud spills located approximately $50 \mathrm{ft}$ east of the fenced U-19q/U-19q PS\#1D potential crater area (REECo, 1991).

Physical Setting - The CAS is located in Area 19 west of the Pahute Mesa Road near the U-19q potential crater area. The three separate mud spills are referred to as the south, north, and west spills and have a total area of approximately 1,167 $\mathrm{ft}^{2}$. The south mud spill is the smallest and measures 
approximately $216 \mathrm{ft}^{2}$ and consists of a thin weathered layer of brown-gray powdery mud that overlies a cracked harder layer of darker gray mud. The west spill is approximately $458 \mathrm{ft}^{2}$ and consists of a 1-ft-thick layer of crumbled gray mud overlying a 3-ft mound of native soil. The north spill is approximately $493 \mathrm{ft}^{2}$ and appears to be consist of gray grout aggregate with areas of yellow staining. Black wire debris and wood fencing debris are visible on the surface. The nearest USGS monitoring well to this CAS is Water Well U-19bk at about $1.9 \mathrm{mi}$ northwest of the CAS and has a depth to groundwater of 2,198 ft bgs (USGS/DOE, 2006b). The nearest water use well is inactive and located about 2.0 mi southeast of the CAS (USGS/DOE, 2006a).

Operational History - The area was used for conducting an underground weapons-related test at U-19q. The LLNL Camembert test was conducted on June 26, 1975, as a part of Operation Bedrock (DOE/NV, 2000). Based on proximity, CAS 19-99-11 mud spill is believed to be associated with post-test drilling activities at drill hole U-19q PS\#1D. Therefore, the mud spill release is assumed to be similar in operation and composition to NTS mud pit material (DOE/NV, 2001).

Release Information - An environmental release associated with drilling activities occurred adjacent to the U-19q potential crater area. The release may contain TPH and potentially radioactive constituents based on process knowledge of mud pits and drilling processes.

Previous Investigation Results - No site specific geophysical or radiological surveys or analytical results were identified for this CAS.

\section{B.2.3 CAS 20-09-09, Mud Spill}

Corrective Action Site 20-09-09 consists of the environmental release associated with two bentonite mud spills located approximately $20 \mathrm{ft}$ south of mud mixing plants at the Area 20 Pahute Mesa Mud Plant (REECo, 1992).

Physical Setting - The site is located in the Pahute Mesa Mud Plant at RSM 20 P 114 in Area 20 and consists of two dry substance spills of dry, cracked gray bentonite on the ground surface. The dimensions of the each spill are approximately 3 by $12 \mathrm{ft}$ and 2 to $12 \mathrm{in}$. thick. The dimensions are easily visible compared to the graded pad/road surface. The soil within and around the site appears to be native volcanic rock. The nearest well to CAS 20-09-09 is U20WW, located about $700 \mathrm{ft}$ 
southwest of the CAS, at a depth of 2,050 ft bgs, and is an active withdrawal location for institutional use of water (USGS/DOE, 2006a).

Operational History - The site is the location of the inactive Pahute Mesa Mud Plant at which mud mixing and water distribution operations for drilling activities in Pahute Mesa were conducted (Geary, 1965). Mud was generated at the plant for use in Area 20 drilling activities. Drilling mud is typically a combination of powdered bentonite clay mixed with water to form a viscous fluid (REECo, 1994). The dry substance spill is believed to have resulted from these mud mixing activities and not used in actual drilling processes. Currently the site is marked as a DOE Operational Readiness Area.

Release Information - An environmental release associated with mud mixing activities occurred north of the mud mixing machines.

Previous Investigation Results - No site specific geophysical or radiological surveys or analytical results were identified for this CAS.

\section{B.2.4 CAS 20-99-03, Mud Spill}

Corrective Action Site 20-99-03 consists of the environmental release associated with the mud spill located south/east of the fenced U-20aq crater area (REECo, 1991).

Physical Setting - The mud spill is located in Area 20 south of the U-20aq crater area and consists of one continuous area of dried mud on the ground surface. The spill area measures approximately 750 by $300 \mathrm{ft}$ and is light pinkish-brown clay/silty material, dry, and cracked. The thickness varies between 1 to 6 in. thick. A pile of small steel pellets (based on visual observations of rust) is located on the northeast side of the spill but does not represent a health hazard. The dimensions of the mud spill are easily visible against the native black/red volcanic surface and an active dirt road dissects the spill in half. The nearest well is U-20WW, an unused test well, that is located approximately $2.4 \mathrm{mi}$ south of the CAS (USGS/DOE, 2006a).

Operational History - The area was used for conducting the underground Darwin test by LLNL and the United Kingdom on June 25, 1986, in U-20aq (DOE/NV, 2000; RSN, 1991). Based on proximity to U-20aq, CAS 20-99-03 mud spill is believed to be associated with post-test drilling activities at 
U-20aq. There is a potential that mud may have been drained in this area from metal piping used in drilling operations to direct the drilling fluids/cuttings from the drill hole to the mud pit. Another possibility is that a holding tank containing drill mud may have spilled in the area. Therefore, the mud spill release is assumed to be similar in operation and composition to NTS mud pit material (DOE/NV, 2001).

Release Information - An environmental release associated with drilling activities occurred adjacent to the U-19aq crater area. The release may contain TPH and potentially radioactive constituents based on process knowledge of mud pits and drilling processes.

Previous Investigation Results - No geophysical survey or analytical results were identified for this CAS. A radiological survey was conducted in 2006, and it was determined that the site poses no risk from residual radiological contamination (SNJV, 2006). 


\section{B.3.0 Step 1 - State the Problem}

Step 1 of the DQO process defines the problem that requires study, identifies the planning team, and develops a conceptual model of the environmental hazard to be investigated.

The problem statement for CAU 553 is: "Sufficient historical and analytical information is available to support a no further action closure alternative for all CASs in CAU 553; however, verification samples are required to confirm the absence of COCs at levels that could pose a risk to human health or the environment."

\section{B.3.1 Planning Team Members}

The DQO planning team consists of representatives from NDEP, NNSA/NSO, Stoller-Navarro Joint Venture (SNJV), and National Security Technologies, LLC. The primary decision-makers are the NDEP and NNSA/NSO representatives. Table B.3-1 lists representatives from each organization in attendance at the July 27, 2006, DQO meeting.

Table B.3-1

Data Quality Objective Meeting Participants for CAU 553 July 27, 2006

(Page 1 of 2)

\begin{tabular}{|c|c|}
\hline Affiliation & Department/Project Team Function \\
\hline \hline NDEP & NDEP Representative \\
\hline NNSA/NSO & $\begin{array}{c}\text { Environmental Restoration Project Federal Industrial Sites } \\
\text { Sub-Project Task Manager }\end{array}$ \\
\hline NSTec & Environmental Restoration Deputy Project Manager \\
\hline NSTec & Environmental Restoration Field Support Manager \\
\hline SNJV & Industrial Sites Project Manager \\
\hline SNJV & Industrial Sites Technical Coordinator \\
\hline SNJV & Industrial Sites (CAU 553) Task Lead \\
\hline SNJV & Federal Facility Agreement and Consent Order Representative \\
\hline SNJV & Quality Assurance Representative \\
\hline SNJV & Analytical Services Chemical Data Validator \\
\hline SNJV & Analytical Services Radiological Data Validator \\
\hline
\end{tabular}


Table B.3-1

Data Quality Objective Meeting Participants for CAU 553 July 27, 2006

(Page 2 of 2)

\begin{tabular}{|c|c|}
\hline Affiliation & Department/Project Team Function \\
\hline \hline SNJV & Health and Safety Group Representative \\
\hline SNJV & Environmental Compliance and Waste Management Representative \\
\hline SNJV & Radiation Services Health Physicist \\
\hline
\end{tabular}

NSTec $=$ National Security Technologies, LLC

NDEP $=$ Nevada Division of Environmental Protection

NNSA/NSO = U.S. Department of Energy, National Security Administration Nevada Site Office

SNJV = Stoller-Navarro Joint Venture

\section{B.3.2 Conceptual Site Model}

The CSM is used to organize and communicate information about site characteristics. It reflects the best interpretation of available information at any point in time. The CSM is a primary vehicle for communicating assumptions about release mechanisms, potential migration pathways, or specific constraints. It provides a summary of how and where contaminants are expected to move, and what impacts movement may have. It is the basis for assessing how contaminants could reach receptors both in the present and future. The CSM describes the most probable scenario for current conditions at each site and defines the assumptions that are the basis for identifying appropriate sampling strategy and data collection methods. Accurate CSMs are important as they serve as the basis for all subsequent inputs and decisions throughout the DQO process.

The CSM was developed for CAU 553 using information from the physical setting, potential contaminant sources, release information, historical background information, knowledge from similar sites, and physical and chemical properties of the potentially affected media and COPCs.

The CSM represents contamination of the surrounding environment due to migration of contaminants that either are currently, or were formerly, present at each of the CASs. Migration of contaminants to areas not presently impacted can occur through infiltration and percolation of contaminants into the soil profile, lateral transportation (overland flow) of some contaminants as a result of surface water runoff or overflow of accumulated surface water in mud pits, or wind-borne resuspension of contaminated surface particles. 
The CSM consists of:

- $\quad$ Potential contaminant releases, including media subsequently affected.

- Release mechanisms (the conditions associated with the release).

- Potential contaminant source characteristics, including contaminants suspected to be present.

- $\quad$ Site characteristics, including physical and meteorological information.

- Migration pathways and transport mechanisms that describe the potential for migration and where the contamination may be transported.

- The locations of points of exposure where individuals or populations may come in contact with a COC associated with a CAS.

- Routes of exposure.

If additional elements are identified during the investigation that are outside the scope of this CSM, the situation will be reviewed and a recommendation will be made as to how to proceed. In such cases, NDEP and NNSA/NSO will be notified and given the opportunity to comment on and concur with the recommendation.

The applicability of this CSM to the mud pits is summarized in Table B.3-2 and discussed below. Table B.3-2 provides information on CSM elements that will be used throughout the remaining steps of the DQO process. Figure B.3-1 represents site conditions applicable to the CSM.

\section{B.3.2.1 Contaminant Release}

The mud spills of CAU 553 are assumed to have similar releases as those identified for the NTS mud pits in CAUs 530-535 and CAU 177. It is unknown whether the spills occurred before or after use in the drilling process where diesel and/or radioactivity may have been released. It can also be reasonably assumed the spill material composition is similar (i.e., mud/clay composition and properties) regardless if the release was associated with pre- or post-test drilling activities.

Although the RBCSR eliminated VOCs, SVOCs, PCBs, and metals as COPCs from NTS mud pits (based on the conclusion that there is no analytical or process knowledge to suggest these constituents are present at significant concentrations in residual mud), it was the most frequently detected 
Table B.3-2

Analytical Program ${ }^{\mathrm{a}}$

\begin{tabular}{|c|c|}
\hline Analyses $^{b}$ & All Corrective Action Sites \\
\hline \multicolumn{2}{|l|}{ Organic COPCs } \\
\hline Total Petroleum Hydrocarbons-Diesel-Range Organics & $x$ \\
\hline Semivolatile Organic Compounds ${ }^{c}$ & $x$ \\
\hline Volatile Organic Compounds ${ }^{c}$ & $\mathrm{X}$ \\
\hline \multicolumn{2}{|c|}{ Radionuclide COPCs } \\
\hline Gamma Emitters & $\mathrm{x}$ \\
\hline Isotopic Uranium & $x$ \\
\hline Isotopic Plutonium & $\mathrm{X}$ \\
\hline Strontium-90 & $\mathrm{X}$ \\
\hline
\end{tabular}

${ }^{a}$ The COPCs are the analytes reported from the analytical methods listed in Table B.5-1.

'If the volume of material is limited, prioritization of the analyses will be necessary.

"May also include Toxicity Characteristic Leaching Procedure analytes if sample is collected for waste management purposes.

COPC $=$ Contaminant of potential concern

$\mathrm{X}=$ Required analytical method

contaminant in residual mud. To be conservative, it was determined that the investigation of CAU 553 would evaluate the risk posed by TPH-DRO and verify the closure strategy of no further action for CAU 553 mud pits. Because complete information regarding activities performed at the CAU 553 mud spills is not available, VOCs, SVOCs, and radionuclides will also be included as COPCs.

The process associated with potential contamination at a mud pit is assumed to be the same process that may have contributed to contamination at a mud spill. The following section will address the release of contaminants associated with the drilling mud.

\section{B.3.2.2 Potential Contaminants}

The COPCs for CAU 553 are defined as the analytes reported from the analyses identified in Table B.3-2. The list of COPCs is applicable to Decision I environmental samples from each mud spill and is intended to encompass all of the contaminants that could potentially be present. These contaminants were identified during the planning process through the review of site history, process 


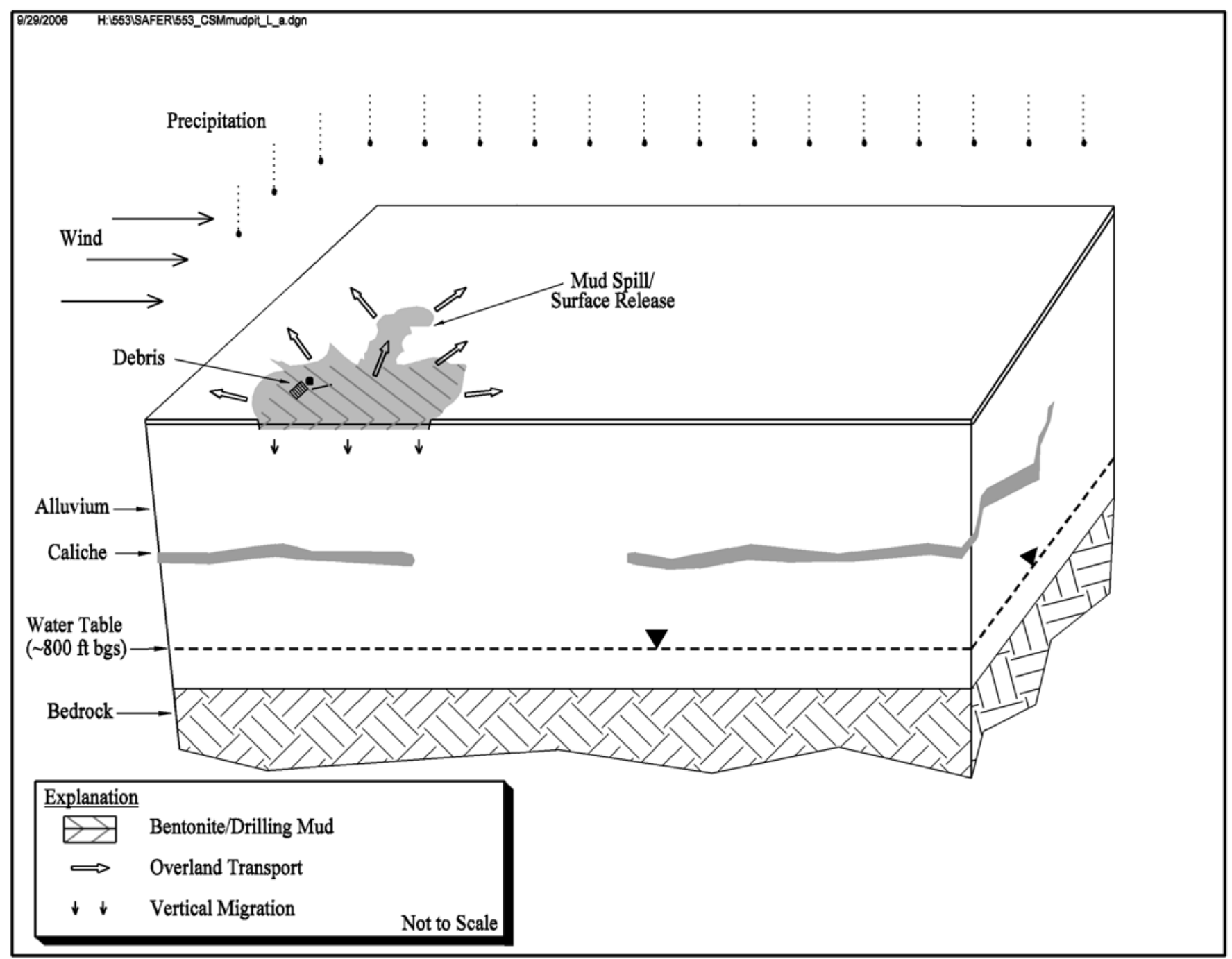

Figure B.3-1

Site Conceptual Model

UNCONTROLLED when Printed 
knowledge, personal interviews, past investigation efforts (where available), and inferred activities associated with the drilling mud processes.

Target analytes are those contaminants for which evidence and available site and process information suggests that they may be reasonably suspected to be present at a given CAS. The targeted contaminants are required to meet a more stringent completeness criteria than other COPCs, thus providing greater protection against a decision error. For this investigation, no targeted analytes have been identified.

\section{B.3.2.3 Contaminant Characteristics}

Contaminant characteristics include, but are not limited to solubility, density, and adsorption potential. In general, contaminants with large particle size, low solubility, high affinity for media, and/or high density can be expected to be found relatively close to release points. Contaminants with small particle size, high solubility, low affinity for media, and/or low density are found further from release points or in low areas where evaporation or ponding will concentrate dissolved contaminants.

The primary source of hydrocarbon contamination is the introduction of diesel as a lubricant during the drilling process. The primary source of potential radiological contamination is the release of drilling mud that may have been in contact with radioactive rock and circulated from the borehole to the mud pit during post-test drilling. Process knowledge indicates that bentonite clay is a major ingredient in drilling mud (IMANA, 2004). In general, clay minerals have high porosity, low permeability, and the property of expanding several times its original volume when saturated with water. This clay-water mixture has a viscosity several times that of water, making it useful as a drilling fluid (DOE/NV 1998a). Based on the unique properties of bentonite and its prominent occurrence in drilling mud, it is believed that its use would help retard the migration of COPCs present in the mud. Furthermore, the residual drilling mud contained within the mud spill is expected to act as a barrier to prevent the downward migration of contaminants into underlying native soil. The document Evaluation of Potential Hydrocarbon Transport at the UC-4 Emplacement Hole, Central Nevada Test Area (DOE/NV, 1998a) reports data that support the conclusion that contamination within drilling mud does not migrate significantly based on TPH release experiments. 


\section{B.3.2.4 Site Characteristics}

Site characteristics are the physical, topographical, and meteorological attributes and properties. Table B.3-3 lists the physical setting of the CAU 553 CASs. Listed for each CAS is the number of individual spills within the CAS boundary and the approximate dimensions of each spill area. In general, the mud spills are expected to have similar characteristics as NTS mud pits because they were all released within the surface soil of the NTS using comparable mud pit processes.

Table B.3-3

Physical Setting of CAU 553 Corrective Action Sites

\begin{tabular}{|c|c|c|c|c|}
\hline CAS & $19-99-01$ & 19-99-11 & 20-09-09 & $20-99-03$ \\
\hline Number of Spill Areas & 1 & 3 & 2 & 1 \\
\hline Mud Spill Dimensions & $1,247 \mathrm{ft}^{2}$ & $\begin{array}{l}\text { North }\left(493 \mathrm{ft}^{2}\right) \\
\text { South }\left(216 \mathrm{ft}^{2}\right) \\
\text { West }\left(458 \mathrm{ft}^{2}\right)\end{array}$ & $\begin{array}{c}\text { Each about } \\
12 \times 3 \mathrm{ft}\end{array}$ & $750 \times 250 \mathrm{ft}$ \\
\hline Radiological Postings & \multicolumn{4}{|c|}{ None } \\
\hline Fence & \multicolumn{4}{|c|}{ None } \\
\hline Associated Test & $\begin{array}{c}\text { Chancellor Test } \\
1983\end{array}$ & $\begin{array}{c}\text { Camembert Test } \\
1975\end{array}$ & N/A & $\begin{array}{c}\text { Darwin Test } \\
1986\end{array}$ \\
\hline Test Release & \multicolumn{4}{|c|}{ None identified } \\
\hline
\end{tabular}

$\mathrm{ft}=$ Foot

$\mathrm{ft}^{2}=$ Square foot

$\mathrm{N} / \mathrm{A}=$ Not applicable

The locations for a release of drilling mud are directly onto the ground surface. The media affected by a release is typically the surface and shallow subsurface soil; however, due to the binding properties of bentonite, contamination is expected to be bound within the mud with no migration to the native soil underlying the mud spills. Contamination, if any, is expected to be evenly dispersed and present at relatively uniform concentrations because the mud would have been homogenized as it was circulated. This suggests that surface samples of the residual mud would be representative of the mud throughout the depth of the mud spill. Contamination unrelated to the mud mixing/use process may be localized beneath potentially hazardous discarded drilling materials, if present. 


\section{B.3.2.4.1 Groundwater}

Groundwater contamination is not considered a likely scenario at any CAS based on the depth to groundwater in Areas 19 and 20. Data from nearest wells indicate that groundwater levels may range from 2,100 to 2,800 ft bgs for Area 19 and 20 CASs (USGS/DOE, 2006a). Surface migration is not expected to be significant because the characteristics of bentonite and/or clay material produce a high tension surface in which particles are not easily mobile even when saturated.

\section{B.3.2.4.2 Migration Pathways and Transport Mechanisms}

An important element of the CSM is the expected fate and transport of contaminants (i.e., how contaminants migrate through media and where they can be expected in the environment). Fate and transport of contaminants are presented in the CSM as the migration pathways and transport mechanism that could potentially move the contaminants vertically and laterally throughout the various media. The pathways include air, surface water, and groundwater, and are the routes through which possible contamination could migrate from the site(s) to locations where a receptor might receive an exposure. Fate and transport are influenced by physical and chemical characteristics of the contaminants and media described in Sections B.3.2.3 and B.3.2.4. Given the characteristics of both the contaminants and the bentonite drilling mud, contaminant migration is expected to be limited.

Infiltration and percolation of precipitation serves as a driving force for the downward vertical migration of contaminants through the mud or underlying soil. The annual potential evapotranspiration at the Area 5 Radiological Waste Management Site has been estimated at 62.6 in. (Shott et al., 1997), but the precipitation for this region is between 3.5 and 6 in. per year (Winograd and Thordarson, 1975). Therefore, percolation of infiltrated precipitation at the NTS does not provide a significant mechanism for vertical migration of contaminants to groundwater (DOE/NV, 1992; NNSA/NSO, 2004a).

Lateral migration of contaminants through impacted media is expected to be limited to within the physical boundaries of the mud spills due to the binding and high sorption properties of clay/bentonite. Lateral migration may occur as a result of overland flow or erosion and is dependant on the percentage of clay/bentonite within the spill matrix. However, visible observations of the mud spill areal extent suggestions lateral migration has been limited over time. 
Releases to the air may result from resuspension of contaminated surface soil particles with wind movement. Wind could potentially suspend surface soil particles and carry them beyond the boundaries of the mud spills but only if the hardened, partially cemented bentonite and/or mud is physically disturbed. Overall, airborne migration of contaminants is considered a minor transport mechanism for CAU 553.

\section{B.3.2.5 Exposure Scenarios}

Human receptors may be exposed to COPCs through oral ingestion, inhalation, or dermal contact (absorption) of drilling mud, soil, or debris due to inadvertent disturbance of these materials, or through irradiation by radioactive materials. The exposure of workers and visitors to site contaminants is very dependent upon the activites of the exposed individual at the site. Based on the future land use as identified in the Nevada Test Site Resource Management Plan (DOE/NV, 1998b), the areas in which all CAU 553 CASs are located are restricted to industrial uses.

The appropriate exposure scenarios for all CAU 553 CASs is the Occasional Use Area, due to each site being in a remote area with no active improvements and the future land use designation is for outdoor tests and/or military training exercises. There is still the possibility, however, that site workers could occupy these locations on an occasional and temporary basis such as a military exercise (NNSA/NSO, 2006b). Investigation decisions will be based on the future land-use and exposure scenarios for CAU 553 that are provided in Table B.3-4.

Table B.3-4

Future Land-Use and Exposure Scenarios

\begin{tabular}{|c|c|c|}
\hline $\begin{array}{c}\text { Corrective } \\
\text { Action Sites }\end{array}$ & Future Land-Use Zone & Exposure Scenario \\
\hline All & $\begin{array}{l}\text { Nuclear and High Explosives Test } \\
\text { This area is designated within the Nuclear } \\
\text { Test Zone for additional underground } \\
\text { nuclear weapons tests and outdoor } \\
\text { high-explosive tests. This zone includes } \\
\text { compatible defense and nondefense } \\
\text { research, development, and testing } \\
\text { activities }\end{array}$ & $\begin{array}{l}\text { Occasional Use Area } \\
\text { This exposure scenario assumes exposure to industrial } \\
\text { workers who are not assigned to the area as a regular } \\
\text { worksite but may occasionally use the site for } \\
\text { intermittent or short-term activities. } \\
\text { A site worker under this scenario is assumed to be on } \\
\text { the site for } 8 \text { hours per day, } 10 \text { days per year, for } \\
5 \text { years. }\end{array}$ \\
\hline
\end{tabular}

Source: DOE/NV, 1998b; NNSA/NSO, 2006b 


\section{B.4.0 Step 2 - Identify the Goal of the Study}

Step 2 of the DQO process states the manner in which environmental data will be used to meet objectives and solve the problem; identifies study questions or decision statement(s), and considers alternative outcomes or actions that can occur upon answering the question(s).

\section{B.4.1 Decision Statements}

The Decision I statement is: "Is any COPC present in environmental media within a mud spill at a concentration exceeding its corresponding action level?” No further action will be supported if no COPCs are identified above corresponding action levels. For judgmental sampling design, any analytical result for a COPC above the FAL will result in that COPC being designated as a COC. If a COC is detected and remediation is feasible, then contaminated media may be removed for disposal and additional samples collected (see Figure 1-2). If a COC is detected and remediation is not feasible, then Decision II must be resolved.

The Decision II statement is: "If a COC is present, is sufficient information available to meet closure objectives?” Sufficient information is defined to include:

- Identifying the volume of media containing any COC, as bounded by analytical sample results in lateral and vertical directions.

- $\quad$ The information needed to characterize IDW for disposal.

- The information needed to determine potential remediation waste types.

- The information needed to evaluate the feasibility of potential closure options.

If sufficient information is not available to meet closure objectives then site conditions will be re-evaluated and additional samples will be collected (as long as the scope of the investigation is not exceeded and any CSM assumption has not been shown to be incorrect).

\section{B.4.2 Alternative Actions to the Decisions}

In this section, the actions that may be taken to solve the problem statement are identified depending on the possible outcomes of the investigation. 


\section{B.4.2.1 Alternative Actions to Decision I}

If no COC associated with a release from the CAS is detected, then the mud spill will be closed via the no further action alternative. If a COC associated with a release from the CAS is detected, then the extent of COC contamination will be determined and additional information will be required to confirm that closure objectives were met.

\section{B.4.2.2 Alternative Actions to Decision II}

If sufficient information is available to define the extent of COC contamination, then a closure strategy of closure in place with administrative controls will be implemented and further assessment of the CAS is not required. If sufficient information is not available to define the extent of COC contamination and confirm that closure objectives were met, then additional samples will be collected. 


\section{B.5.0 Step 3 - Identify Information Inputs}

This step identifies the information needed, determines sources for information, and identifies sampling and analysis methods that will allow reliable comparisons of analytical results with FALs.

\section{B.5.1 Information Needs}

To resolve Decision I (determine whether a COC is present at a given CAS), samples need to be collected and analyzed following two criteria: (1) samples must be collected in areas most likely to contain a COC (judgmental sampling); and (2) the analytical suite selected must be sufficient to identify any COCs present in the samples.

To resolve Decision II (determine whether sufficient information is available to meet closure objectives at each CAS), samples shall be collected and analyzed to meet the following criteria:

- Samples must be collected in areas contiguous to the contamination but where contaminant concentrations are below FALs.

- Samples of the waste or environmental media must provide sufficient information to characterize the IDW for disposal.

- The analytical suites selected must be sufficient to detect contaminants at concentrations equal to or less than their corresponding FALs.

\section{B.5.2 Sources of Information}

Information to satisfy Decision I and Decision II will be generated by collecting environmental samples using grab sampling, hand augering, or other appropriate sampling methods. These samples will be submitted to analytical laboratories meeting the quality criteria stipulated in the Industrial Sites QAPP (NNSA/NV, 2002). Only validated data from analytical laboratories will be used to support DQO decisions. Sample collection and handling activities will follow standard procedures.

\section{B.5.2.1 Sample Locations}

Design of the sampling approaches for the CAU 553 CASs must ensure that the data collected are sufficient for supporting the selection of a corrective action alternative (EPA, 2002). To meet this 
objective, the samples collected from each site should be from locations that either most likely contain a COC, if present, or from a location that will accurately confirm the absence of contamination within the CAS.

A judgmental sampling approach will be implemented for all mud spills. Biasing factors (including FSRs) will be used to select the most appropriate samples from a particular location for submittal to the analytical laboratory. Biasing factors to be used for selection of sampling locations are listed in Section B.5.2.1.1. Sample locations may be modified based on site conditions, obvious debris or staining of soils, FSRs, or professional judgment if the modified locations meet the DQO decision needs and criteria stipulated. As biasing factors are identified and used for selection of sampling locations, they will be recorded in the appropriate field documents.

The implementation of the judgmental sampling approach for CAU 553 is summarized in the following section.

\section{B.5.2.1.1 Judgmental Approach for Sample Location Selection}

Decision I sample locations at mud spills will be determined based upon the likelihood of the mud, or soil in the case of CAS 20-09-09, containing a COC, if present. These locations will be selected based on field-screening techniques, biasing factors, the CSM, and existing information. Analytical suites for Decision I samples will include all COPCs identified in Table B.3-2.

Field-screening techniques may be used to select appropriate sampling locations by providing semi-quantitative data that can be used to comparatively select samples to be submitted for laboratory analyses from several screening locations. Field screening may also be used for health and safety monitoring and to assist in making certain health and safety decisions. The following field-screening methods may be used to select analytical samples at CAU 553:

- Walkover surface area radiological surveys - A vehicle-mounted or handheld radiological survey instrument over approximately 100 percent of the CAS boundaries, as permitted by terrain and field conditions to detect hot spots of radiological contamination.

- Alpha and beta/gamma radiation - A handheld radiological survey instrument, or equivalent instrument or method, may be used at these CASs. 
- Gamma-emitting radionuclides - A handheld dose rate instrument.

Biasing factors may also be used to select samples to be submitted for laboratory analyses based on existing site information and site conditions discovered during the investigation. The following biasing factors will be considered in selecting locations for analytical samples at CAU 553:

- Documented process knowledge on source and location of release.

- Topography: Topographic lows within the spill area where contaminants could be expected to be concentrated.

- Stains: Any spot or area on the soil surface that may indicate the presence of a potentially hazardous liquid release. Typically, stains indicate an organic liquid such as an oil has reached the soil, and may have spread out vertically and horizontally.

- Elevated radiation: Any location identified during radiological surveys that had alpha/beta/gamma levels significantly higher than surrounding background soil.

- Geophysical anomalies: Any location identified during geophysical surveys that had results indicating subsurface materials exist and are not consistent with the natural surroundings or process knowledge (e.g., buried concrete or metal, surface metallic objects).

- Drums, containers, equipment or debris: Materials of interest that may have been used at, or added to, a location, and that may have contained or come in contact with hazardous or radioactive substances at some point during their use.

- Lithology: Locations where variations in lithology (soil or rock) indicate that different conditions or materials exist.

- Preselected areas based on process knowledge of the site: Locations for which evidence such as historical photographs, experience from previous investigations, or interviewee input exists that a release of hazardous or radioactive substances may have occurred.

- Preselected areas based on process knowledge of the contaminant(s): Locations that may reasonably have received contamination, selected on the basis of the chemical and/or physical properties of the suspected contaminant(s) in that environmental setting.

- Other biasing factors: Factors not previously defined for the investigation, but become evident once the investigation of the site is under way.

Decision II sample step-out locations will be selected based on the CSM, biasing factors, and existing data. Analytical suites will include those parameters that exceeded FALs (i.e., COCs) in previous 
samples. Biasing factors to support Decision II sample locations include Decision I biasing factors plus available analytical results.

\section{B.5.2.2 Analytical Methods}

Analytical methods are available to provide the data needed to resolve the decision statements. The analytical methods and laboratory requirements (e.g., detection limits, precision, and accuracy) are specified in Sections 7.2.1 and 7.2.2 of this document. Table B.5-1 lists the analytes reported by the various analytical methods that are considered to be COPCs. 
Table B.5-1

Analytes Reported by Analytical Methods

\begin{tabular}{|c|c|c|c|c|}
\hline \multicolumn{2}{|c|}{ VOC } & SVOC & TPH & Radionuclides \\
\hline $\begin{array}{l}\text { 1,1,1-Trichloroethane } \\
\text { 1,1,1,2-Tetrachloroethane } \\
\text { 1,1,2,2-Tetrachloroethane } \\
\text { 1,1,2-Trichloroethane } \\
\text { 1,1-Dichloroethane } \\
\text { 1,1-Dichloroethene } \\
\text { cis-1,2-Dichloroethene } \\
\text { 1,2-Dichloroethane } \\
\text { 1,2-Dichloropropane } \\
\text { 1,2,4-Trichlorobenzene } \\
\text { 1,2,4-Trimethylbenzene } \\
\text { 1,2-Dibromo-3-chloropropane } \\
\text { 1,3,5-Trimethylbenzene } \\
\text { 1,4-Dioxane } \\
\text { 2-Butanone } \\
\text { 2-Chlorotoluene } \\
\text { 2-Hexanone } \\
\text { 4-Methyl-2-pentanone } \\
\text { Acetone } \\
\text { Acetonitrile } \\
\text { Allyl chloride } \\
\text { Benzene } \\
\text { Bromodichloromethane } \\
\text { Bromoform } \\
\text { Bromomethane } \\
\text { Carbon disulfide } \\
\text { Carbon tetrachloride } \\
\text { Chlorobenzene } \\
\text { Chloroethane } \\
\text { Chloroform } \\
\text { Chloromethane } \\
\text { Chloroprene } \\
\text { Dibromochloromethane } \\
\text { Dichlorodifluoromethane } \\
\text { Ethyl methacrylate } \\
\text { Ethylbenzene } \\
\text { Isobutyl alcohol } \\
\text { Isopropylbenzene } \\
\text { m-Dichlorobenzene (1,3) } \\
\text { Methacrylonitrile } \\
\text { Methyl methacrylate }\end{array}$ & $\begin{array}{l}\text { Methylene chloride } \\
\text { N-Butylbenzene } \\
\text { N-Propylbenzene } \\
\text { o-Dichlorobenzene }(1,2) \\
\text { p-Dichlorobenzene }(1,4) \\
\text { p-isopropyltoluene } \\
\text { sec-Butylbenzene } \\
\text { Styrene } \\
\text { tert-Butylbenzene } \\
\text { Tetrachloroethene } \\
\text { Toluene } \\
\text { Total Xylenes } \\
\text { Trichloroethene } \\
\text { Trichlorofluoromethane } \\
\text { Vinyl acetate } \\
\text { Vinyl chloride }\end{array}$ & $\begin{array}{l}\text { 2,3,4,6-Tetrachlorophenol } \\
\text { 2,4-Dimethylphenol } \\
\text { 2,4-Dinitrotoluene } \\
\text { 2,4,5-Trichlorophenol } \\
\text { 2,4,6-Trichlorophenol } \\
\text { 2-Chlorophenol } \\
\text { 2-Methylnaphthalene } \\
\text { 2-Methylphenol } \\
\text { 2-Nitrophenol } \\
\text { 3-Methylphenol } \\
\text { 4-Chloroaniline } \\
\text { 4-Methylphenol } \\
\text { 4-Nitrophenol } \\
\text { Acenaphthene } \\
\text { Acenaphthylene } \\
\text { Aniline } \\
\text { Anthracene } \\
\text { Benzo(a)anthracene } \\
\text { Benzo(a)pyrene } \\
\text { Benzo(b)fluoranthene } \\
\text { Benzo(g,h,i)perylene } \\
\text { Benzo(k)fluoranthene } \\
\text { Benzoic Acid } \\
\text { Benzyl Alcohol } \\
\text { Bis(2-ethylhexyl) phthalate } \\
\text { Butyl benzyl phthalate } \\
\text { Carbazole } \\
\text { Chrysene } \\
\text { Dibenzo(a,h)anthracene } \\
\text { Dibenzofuran } \\
\text { Diethyl Phthalate } \\
\text { Dimethyl Phthalate } \\
\text { Di-n-butyl Phthalate } \\
\text { Di-n-octyl Phthalate } \\
\text { Fluoranthene } \\
\text { Fluorene } \\
\text { Hexachlorobenzene } \\
\text { Hexachlorobutadiene } \\
\text { Hexachloroethane } \\
\text { Indeno(1,2,3-cd)pyrene } \\
\text { Naphthalene } \\
\text { Nitrobenzene } \\
\text { N-Nitroso-di-n-propylamine } \\
\text { Pentachlorophenol } \\
\text { Phenanthrene } \\
\text { Phenol } \\
\text { Pyrene } \\
\text { Pyridine }\end{array}$ & $\begin{array}{l}\text { TPH } \\
\text { (Diesel-Range } \\
\text { Organics) }\end{array}$ & $\begin{array}{l}\text { Plutonium-238 } \\
\text { Plutonium-239/240 } \\
\text { Strontium-90 } \\
\text { Uranium-234 } \\
\text { Uranium-235 } \\
\text { Uranium-238 } \\
\text { Other parameters: } \\
\text { Gamma-emitting } \\
\text { radionuclides } \\
\text { including: } \\
\text { Actinium-228 } \\
\text { Americium-241 } \\
\text { Cesium-137 } \\
\text { Cobalt-60 } \\
\text { Europium-152 } \\
\text { Europium-154 } \\
\text { Europium-155 } \\
\text { Lead-212 } \\
\text { Lead-214 } \\
\text { Niobium-94 } \\
\text { Potassium-40 } \\
\text { Thallium-208 } \\
\text { Thorium-234 } \\
\text { Uranium-235 }\end{array}$ \\
\hline
\end{tabular}

aMay be reported with VOCs

${ }^{\mathrm{b}}$ May be reported as 3,4-methylpenol
SVOC = Semivolatile organic compound

$\mathrm{TPH}=$ Total petroleum hydrocarbons

VOC $=$ Volatile organic compound 


\section{B.6.0 Step 4 - Define the Boundaries of the Study}

Step 4 of the DQO process defines the target population of interest and its relevant spatial boundaries, specifies temporal and other practical constraints associated with sample/data collection, and defines the sampling units on which decisions or estimates will be made.

\section{B.6.1 Target Populations of Interest}

The population of interest to resolve Decision I ("Is any COC present in environmental media within a mud spill?”) is any location within the site that is contaminated with any contaminant above a FAL (judgmental sampling). The populations of interest to resolve Decision II ("If a COC is present, is sufficient information available to meet closure objectives?”) are:

- Each one of a set of locations bounding contamination in lateral and vertical directions.

- Investigation-derived waste or environmental media that must be characterized for disposal.

- $\quad$ Potential remediation waste.

- Environmental media where natural attenuation or biodegradation or construction/evaluation of barriers is considered.

Regardless of the sampling design, the population of interest for this investigation is surface soil ( 0 to 6 in. depth) defined as the residual drilling fluid within the boundary of a mud spill. In the case of CAS 20-09-09, where the residual drilling fluid is recommended for removal under a best management practice, the population of interest is surface soil directly beneath the removed drilling mud.

Following the approved risk-based approach previously used for mud pits, soil samples from the surface of the residual drilling fluid are considered sufficient to adequately characterize the risk posed by mud pits, and similarly, mud spills. A review of data from previous mud pit investigations conducted under the complex process has demonstrated that TPH-DRO concentrations in surface soils are representative of the TPH-DRO concentrations throughout the depth of the residual drilling fluid (NNSA/NSO, 2004a). Although not suspected in the mud spills of CAU 553, the same process would apply to radiological constituents within residual drilling fluid. In addition, considering the 
proposed industrial future land uses, the surface soil is the primary exposure point for future workers. Thus, samples collected from subsurface soils would yield no additional information.

\section{B.6.2 Spatial Boundaries}

Spatial boundaries are the maximum lateral and vertical extent of expected contamination at each mud pit, as shown in Table B.6-1. Contamination found beyond these boundaries may indicate a flaw in the CSM and may require re-evaluation of the CSM before the investigation could continue. Each CAS is considered geographically independent and intrusive activities are not intended to extend into the boundaries of neighboring CASs.

Table B.6-1

Spatial Boundaries of CAU 553 Mud Pits and Cellars

\begin{tabular}{|c|l|}
\hline Feature & \multicolumn{1}{|c|}{ Spatial Boundaries } \\
\hline \hline Mud Spills & $\begin{array}{l}\text { The lateral boundaries are a } 50 \text {-foot lateral buffer from the visible } \\
\text { edges of the mud spills. The vertical boundary will be a depth of } \\
10 \text { feet below ground surface. }\end{array}$ \\
\hline
\end{tabular}

\section{B.6.3 Practical Constraints}

Investigation of these CASs may be impacted by physical constraints and activities at the NTS. General practical constraints include weather, rough terrain, and access restrictions. Access restrictions include scheduling conflicts on the NTS with other entities, areas posted as contamination areas requiring appropriate work controls, areas requiring authorized access, and physical barriers (e.g., fences).

Specific constraints that may cause a temporary delay in sampling include potential restricted access to Area 19 and 20 CASs during winter months due to snow cover; restricted access to mud spills due to ponding of water following inclement weather; and military exercises, which would restrict access to Area 19 and 20.

Identified constraints that can limit intrusive sampling include buried debris, underground utilities, overhead power lines, and underlying geology (i.e., caliche, bedrock). Underground utilities surveys will be conducted at each CAS before starting investigation activities to determine whether utilities exist, and, if so, determining the limit of spatial boundaries for intrusive activities. 


\section{B.6.4 Define the Scale of Decision-Making}

The scale of decision-making for resolving Decision I and Decision II statements is defined as the individual mud spill within each CAS. This allows for individual mud spills within a CAS to be closed independent of one another. For Decision I, any COC identified in a mud spill will cause the determination that the residual mud is contaminated. Because contamination is expected to be bound within the matrix of the drilling mud, further evaluation is not necessary.

For resolving the Decision II statement, the maximum lateral extent would be defined as the visible edges of the mud spill area, and the vertical extent would be the depth of the residual drilling mud/grout, because contaminants are expected to be bound within the matrix of the drilling mud. 


\section{B.7.0 Step 5 - Develop the Analytical Approach}

Step 5 of the DQO process specifies appropriate population parameters for making decisions, defines action levels, and generates an "If ... then ...” decision rule that involves the appropriate population parameter.

\section{B.7.1 Population Parameters}

For judgmental sampling results, the population parameter is the maximum observed concentration of each contaminant from each individual analytical sample. Each sample result will be compared to the FALs to determine the appropriate resolution to Decision I and Decision II. For Decision I, a single sample result for any contaminant exceeding a FAL would cause a determination that a COC is present within the CAS.

The Decision II population parameter is an individual analytical result from a bounding sample. For Decision II, a single bounding sample result for any contaminant exceeding a FAL would cause a determination that the contamination is not bounded.

\section{B.7.2 Action Levels}

The PALs presented in this section are to be used for site screening purposes. They are not necessarily intended to be used as cleanup action levels or FALs. However, they are useful in screening out contaminants that are not present in sufficient concentrations to warrant further evaluation and, therefore, streamline the consideration of remedial alternatives. The RBCA process used to establish FALs is described in the Industrial Sites Project Establishment of Final Action Levels (NNSA/NSO, 2006b). This process conforms with NAC Section 445A.227, which lists the requirements for sites with soil contamination (NAC, 2005). For the evaluation of corrective actions, NAC Section 445A.22705 requires the use of ASTM Method E 1739-95 to "conduct an evaluation of the site, based on the risk it poses to public health and the environment, to determine the necessary remediation standards (i.e., FALs) or to establish that corrective action is not necessary" (ASTM, 1995). 
This RBCA process defines three tiers (or levels) of evaluation involving increasingly sophisticated analyses:

- Tier 1 - Sample results from source areas (highest concentrations) are compared to action levels based on generic (non-site-specific) conditions (i.e., the PALs established in the SAFER). The FALs may then be established as the Tier 1 action levels, or the FALs may be calculated using a Tier 2 evaluation.

- Tier 2 - Conducted by calculating Tier 2 SSTLs using site-specific information as inputs to the same or similar methodology used to calculate Tier 1 action levels. The Tier 2 SSTLs are then compared to individual sample results from reasonable points of exposure (as opposed to the source areas as is done in Tier 1) on a point-by-point basis. Total TPH concentrations will not be used for risk-based decisions under Tier 2 or Tier 3. Rather, the individual chemicals of concern will be compared to the SSTLs.

- $\quad$ Tier 3 - Conducted by calculating Tier 3 SSTLs on the basis of more sophisticated risk analyses using methodologies described in Method E1739-95 that consider site-, pathway-, and receptor-specific parameters.

The comparison of laboratory results to FALs and the evaluation of potential corrective actions will be included in the Closure Report. The FALs will be defined (along with the basis for their definition) in the Closure Report.

\section{B.7.2.1 Chemical PALs}

Except as noted herein, the chemical PALs are defined as the EPA Region 9 Risk-Based Preliminary Remediation Goals (PRGs) for chemical contaminants in industrial soils (EPA, 2004). For detected chemical COPCs without established PRGs, the protocol used by the EPA Region 9 in establishing PRGs (or similar) will be used to establish PALs. If used, this process will be documented in the Closure Report.

\section{B.7.2.2 Total Petroleum Hydrocarbon PALs}

The PAL for TPH is 100 ppm as listed in NAC 445A.2272 (NAC, 2005).

\section{B.7.2.3 Radionuclide PALs}

The PALs for radiological contaminants are based on the NCRP Report No. 129 recommended screening limits for construction, commercial, industrial land-use scenarios (NCRP, 1999) using a 
25 mrem/yr dose constraint (Murphy, 2004) and the generic guidelines for residual concentration of radionuclides in DOE Order 5400.5 (DOE, 1993). These PALs are based on the construction, commercial, and industrial land-use scenario provided in the guidance and are appropriate for the NTS based on future land uses presented in Table B.3-4.

Solid media such as concrete and/or structures may pose a potential radiological exposure risk to site workers if contaminated. The radiological PAL for solid media will be defined as the unrestricted-release criteria defined in the NV/YMP RadCon Manual (NNSA/NSO, 2004b).

\section{B.7.3 Measurement and Analysis Sensitivity}

The measurement and analysis methods specified in Sections 7.2.1 and 7.2.2 of this document and in the Industrial Sites QAPP (NNSA/NV, 2002) are capable of measuring analyte concentrations at or below the corresponding FALs for each COPC. See Section 7.2 for additional details.

\section{B.7.4 Decision Rules}

The decision rules applicable to both Decision I and Decision II are:

- If COC contamination is inconsistent with the CSM or extends beyond the spatial boundaries identified in Section B.6.2, then work will be suspended and the investigation strategy will be reconsidered. For mud spills that are similar to NTS mud pits, if the characteristic concentration of a contaminant exceeds the action level, then the mud spill will be considered contaminated and closure alternatives will be evaluated.

The decision rules for Decision I are:

- If the population parameter of any COPC in the Decision I population of interest (defined in Step 4) exceeds the corresponding FAL, then that analyte is identified as a COC, and removal of the material will be conducted, or Decision II samples will be collected to define the extent of COC contamination. If all COPC concentrations are less than the corresponding action levels in mud spills, then the decision will be no further action.

The decision rules for Decision II are:

- If the population parameter (the maximum observed concentration of any COC) in the Decision II population of interest (defined in Step 4) exceeds the corresponding FAL, then additional samples will be collected to complete the Decision II evaluation. If all bounding 
COC concentrations are less than the corresponding FALs, then the decision will be that the extent of contamination has been defined in the corresponding lateral and/or vertical direction.

- If valid analytical results are available for the waste characterization samples defined in Section B.9.0, then the decision will be that sufficient information exists to characterize the IDW for disposal, determine potential remediation waste types, and to confirm that closure objectives were met. 


\section{B.8.0 Step 6 - Specify Performance or Acceptance Criteria}

Step 6 of the DQO process defines the decision hypotheses, specifies controls against false rejection and false acceptance decision errors, examines consequences of making incorrect decisions from the test, and places acceptable limits on the likelihood of making decision errors.

\section{B.8.1 Decision Hypotheses}

The baseline condition (i.e., null hypothesis) and alternative condition for Decision I are:

- Baseline condition - A COC is present.

- Alternative condition - A COC is not present.

The baseline condition (i.e., null hypothesis) and alternative condition for Decision II are as follows:

- Baseline condition - The extent of a COC has not been defined.

- Alternative condition - The extent of a COC has been defined.

Decisions and/or criteria have false negative or false positive errors associated with their determination. The impact of these decision errors and the methods that will be used to control these errors are discussed in the following subsections. In general terms, confidence in DQO decisions based on judgmental sampling results will be established qualitatively by:

- The development of and concurrence of CSM(s) (based on process knowledge) by stakeholder participants during the DQO process.

- Testing the validity of $\operatorname{CSM}(\mathrm{s})$ based on investigation results.

- Evaluating the quality of the data based on DQI parameters.

\section{B.8.2 False Negative Decision Error}

The false negative decision error would mean deciding that a COC is not present when it actually is (Decision I), or deciding that the extent of a COC has been defined when it has not (Decision II). In both cases, the potential consequence is an increased risk to human health and environment. 


\section{B.8.2.1 False Negative Decision Error for Judgmental Sampling}

In judgmental sampling, the selection of the number and location of samples is based on knowledge of the feature or condition under investigation and on professional judgment (EPA, 2002).

Judgmental sampling conclusions about the target population depend upon the validity and accuracy of professional judgment.

The false negative decision error (where consequences are more severe) for judgmental sampling designs is controlled by meeting these criteria:

1. For Decision I, having a high degree of confidence that the judgmental sample locations selected will identify COCs if present anywhere within the CAS. For Decision II, having a high degree of confidence that the sample locations selected will identify the extent of COCs.

2. Having a high degree of confidence that analyses conducted will be sufficient to detect any COCs present in the samples.

3. Having a high degree of confidence that the dataset is of sufficient quality and completeness.

To satisfy the first criterion, Decision I samples must be collected from areas most likely to be contaminated by COCs (supplemented by random samples where appropriate). Decision II samples must be collected in areas that represent the lateral and vertical extent of contamination (above action levels). The following characteristics must be considered to control decision errors for the first criterion:

- Source and location of release

- Chemical nature and fate properties

- Physical transport pathways and properties

- Hydrologic drivers

These characteristics were considered during the development of the CSM and the selection of sampling locations. The field-screening methods and biasing factors listed in Section B.5.2.1.1 will be used to further ensure that appropriate sampling locations are selected to meet these criteria. Radiological survey instruments and field-screening equipment will be calibrated and checked in accordance with the manufacturer's instructions and approved procedures. The Closure Report will present an assessment on the DQI of representativeness (i.e., that samples were collected from those locations that best represent the populations of interest as defined in Section B.6.1). 
To satisfy the second criterion, Decision I samples will be analyzed for the chemical and radiological parameters listed in Section 4.1. Decision II samples will be analyzed for those chemical and radiological parameters that identified unbounded COCs. The DQI of sensitivity will be assessed for all analytical results to ensure that all sample analyses had measurement sensitivities (detection limits) that were less than or equal to the corresponding FALs. If this criterion is not achieved, the affected data will be assessed (for usability and potential impacts on meeting site characterization objectives) in the Closure Report.

To satisfy the third criterion, the entire dataset, as well as individual sample results, will be assessed against the DQIs of precision, accuracy, comparability, and completeness as defined in the Industrial Sites QAPP (NNSA/NV, 2002) and in Section 7.2. The DQIs of precision and accuracy will be used to assess overall analytical method performance as well as to assess the need to potentially "flag" (qualify) individual analyte results when corresponding QC sample results are not within the established control limits for precision and accuracy. Data qualified as estimated for reasons of precision or accuracy may be considered to meet the analyte performance criteria based on an assessment of the data. The DQI of completeness will be assessed to ensure that all data needs identified in the DQO have been met. The DQI of comparability will be assessed to ensure that all analytical methods used are equivalent to standard EPA methods so that results will be comparable to regulatory action levels that have been established using those procedures. Strict adherence to established procedures and QA/QC protocol protects against false negatives.

To provide information for the assessment of the DQIs of precision and accuracy, the following QC samples will be collected as required by the Industrial Sites QAPP (NNSA/NV, 2002):

- Field duplicates (minimum of 1 per matrix per 20 environmental samples)

- Laboratory QC samples (minimum of 1 per matrix per 20 environmental samples or 1 per CAS per matrix, if less than 20 collected)

\section{B.8.3 False Positive Decision Error}

The false positive decision error would mean deciding that a COC is present when it is not, or a COC is unbounded when it is not, resulting in increased costs for unnecessary sampling and analysis and potentially for unnecessary corrective actions. 
False positive results are typically attributed to laboratory and/or sampling/handling errors that could cause cross contamination. To control against cross contamination, decontamination of sampling equipment will be conducted according to established and approved procedures and only clean sample containers will be used. To determine whether a false positive analytical result may have occurred, the following QC samples will be collected as required by the Industrial Sites QAPP (NNSA/NV, 2002):

- $\quad$ Trip blanks (1 per sample cooler containing VOC environmental samples)

- Equipment rinsate blanks (1 per sampling event for each type of decontamination procedure)

- Source blanks (1 per lot of source material that contacts sampled media)

- Field duplicates (1 per 20 environmental samples or 1 per CAS per matrix, if less than 20)

- Field blanks (1 per 20 environmental samples or 1 per day)

- Laboratory QC samples (1 per 20 environmental samples or 1 per CAS per matrix, if less than 20) 


\section{B.9.0 Step 7 - Develop the Plan for Obtaining Data}

Step 7 of the DQO process selects and documents a design that will yield data to best achieve performance or acceptance criteria. A judgmental sampling design will be implemented for all CAU 553 CASs. Even in the absence of biasing factors, the sampling planned is considered judgmental because of the limited spatial boundaries of each spill. A summary of the sampling approach and data evaluation for each CAS is presented in Table B.9-1. Section B.9.1 provides the specific judgmental sampling approach that will be implemented to select verification sample locations and evaluate analytical results at all CASs.

Table B.9-1

Summary of Sampling Approach and Data Evaluation for CAU 553

\begin{tabular}{|c|c|l|c|}
\hline $\begin{array}{c}\text { Feature with } \\
\text { Applicable CASs }\end{array}$ & Description & Decision I Parameters & Evaluation of Data \\
\hline \hline $\begin{array}{c}19-99-01 \\
19-99-11\end{array}$ & $\begin{array}{c}\text { Judgmental Sampling } \\
20-09-09\end{array}$ & $\begin{array}{l}\text { - Initial \# of locations: } 2 \text { to } 4 \\
\text { Apoil profile depth(s): Surface } \\
20-99-03\end{array}$ & $\begin{array}{c}\text { Point-by-point } \\
\text { comparison of each } \\
\text { analytical result to the } \\
\mathrm{FAL}\end{array}$ \\
\hline
\end{tabular}

CAS $=$ Corrective Action Site

$\mathrm{FAL}=$ Final action level

in. $=$ Inch

Because individual sample results rather than an average concentration will be used to compare to FALs at the CASs undergoing judgmental sampling, statistical methods to generate site characteristics will not be used. Adequate representativeness of the entire target population may not be a requirement to developing a sampling design. If adequate prior information is available on the site of interest, then the sampling may be designed to collect samples only from areas known to have the highest concentration levels on the target site. If the observed concentrations from these samples are below the action level, then a decision can be made that the site contains safe levels of the contaminant without the samples being truly representative of the entire area (EPA, 2006).

All sample locations will be selected to satisfy the DQI of representativeness in that samples collected from selected locations will best represent the populations of interest as defined in Section B.6.1. To meet the DQI criterion for judgmental sampling sites, a biased sampling strategy will be used for Decision I to target areas with the highest potential for contamination, if it is present anywhere in the 
spill area. Sample locations will be determined based on process knowledge, previously acquired data, or the field screening and biasing factors listed in Section B.5.2.1.1. If biasing factors are present in soils below locations where Decision I samples were removed, additional Decision I soil samples will be collected at depth intervals selected by the SS based on biasing factors to a depth where the biasing factors are no longer present. The SS has the discretion to modify the sample locations at judgmentally sampled CASs, but only if the modified locations meet the decision needs and criteria stipulated in this DQO.

\section{B.9.1 Mud Spill Sampling Designs}

Sufficient historical site knowledge and previous sampling results from similar mud pit/spill investigations exist to indicate that the mud spills in CAU 553 can be closed under the no further action alternative. To support this closure alternative, surface verification samples will be collected using a judgmental sampling design from each individual mud spill within CAU 553 to confirm that COCs are not present at concentrations that pose a risk to human health or the environment. Samples to be collected at mud spills will be obtained using hand scoops, hand auger, or other appropriate method. The following sections outline the judgmental sample design for each CAS and also describes any additional activities that may be performed as best management practices. During the investigation for all CASs in CAU 553, the SS has the discretion to modify the sample locations or order additional biased samples to be collected, but only if the new locations meet the decision needs and criteria stipulated in this DQO. The SS will use professional judgment to determine whether biasing factors (e.g., stains, elevated screening levels) are found during Decision I sampling that might indicate the need to take subsurface Decision II samples.

\section{B.9.1.1 CAS 19-99-01, Mud Spill}

The mud spill at this CAS is not contiguous and is located in several areas on and surrounding an 8-ft-high soil mound. The thickest concentrations of mud/clay material can be found in localized shallow depressions atop the mound and low areas on the ground surface at the base of the mound where the mud spilled down the sides. A minimum of two biased samples will be collected from the mound area with the locations biased towards staining, elevated FSRs, and/or the thickest deposits of mud assuming any COPCs will be concentrated in these areas. Debris surrounding the mud spill within the CAS boundaries will not be removed or investigated. Geophysical surveys of the mound 
indicate no debris is buried and the nature of the mud spill suggests that mud was only deposited on the mound surface. Figure B.9-1 shows the proposed sample locations.

\section{B.9.1.2 CAS 19-99-11, Mud Spill}

This CAS has three distinct mud spill areas. Verification samples will be collected from each spill in a location with the highest potential to find contamination if present. In the absence of staining or elevated FSRs, a sample will be collected in either the topographic low within the spill area where contaminants could be expected to be concentrated or in the center of the spill if no other biasing factors exist. For the North spill, it is anticipated the grout material will be sampled directly in two locations, with at least one location at a yellow-stained area on the north end. For the West spill, the darker gray silt/clay material lying atop the native volcanic material will be sampled. For the South spill, any stained area or the darkest gray coloring of the mud will be sampled. Figure B.9-2 shows the proposed sample locations.

\section{B.9.1.3 CAS 20-09-09, Mud Spill}

Due to the location of the two bentonite spills within an DOE Operational Readiness Area, it is recommended that both bentonite piles be removed as a best management practice and managed as a waste. Samples will be collected from the material directly for waste management purposes. A soil verification sample will then be collected from beneath each of the removed bentonite piles to confirm the absence of COPCs in the underlying soil. If COCs are shown to be present, then Decision II samples will be collected, if deemed necessary. Figure B.9-3 shows the proposed sample locations.

\section{B.9.1.4 CAS 20-99-03, Mud Spill}

The mud spill at this CAS is contiguous and encompasses a large area (750 by $250 \mathrm{ft}$ ) where the mud is relatively evenly distributed across the site. This mud spill is the only area of concern for this CAS. The pile of steel pellets (based on visual observation of rust) located north of the mud spill does not represent an environmental hazard and therefore will not be investigated further. A radiological survey performed on the mud spill indicates no elevated radiological contamination. Based on these data and previous mud pit sampling investigation results, there is no indication that a fuller characterization of the spill area is necessary. Therefore, only four verification samples are 


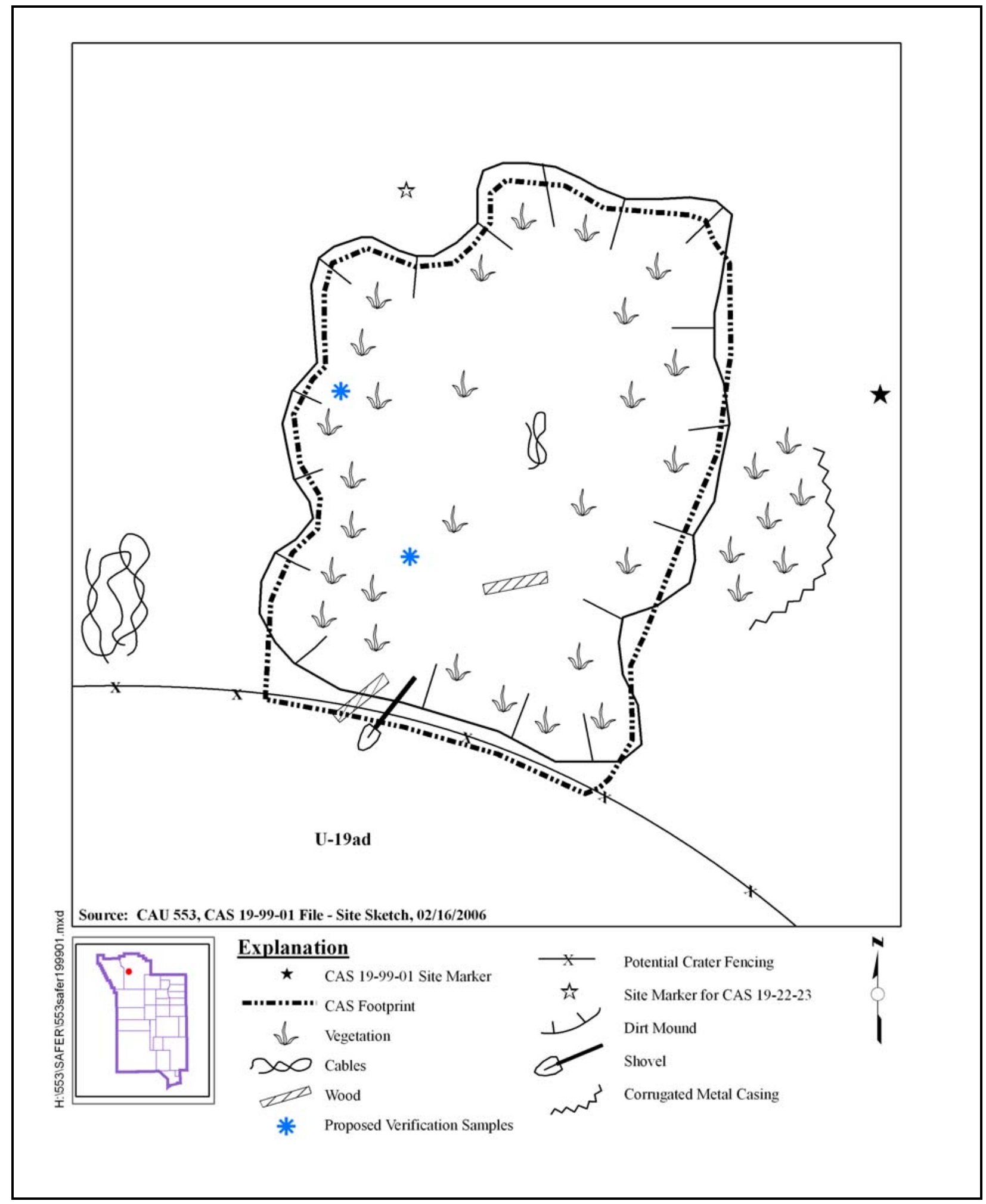

Figure B.9-1

Proposed Sample Locations CAS 19-99-01 


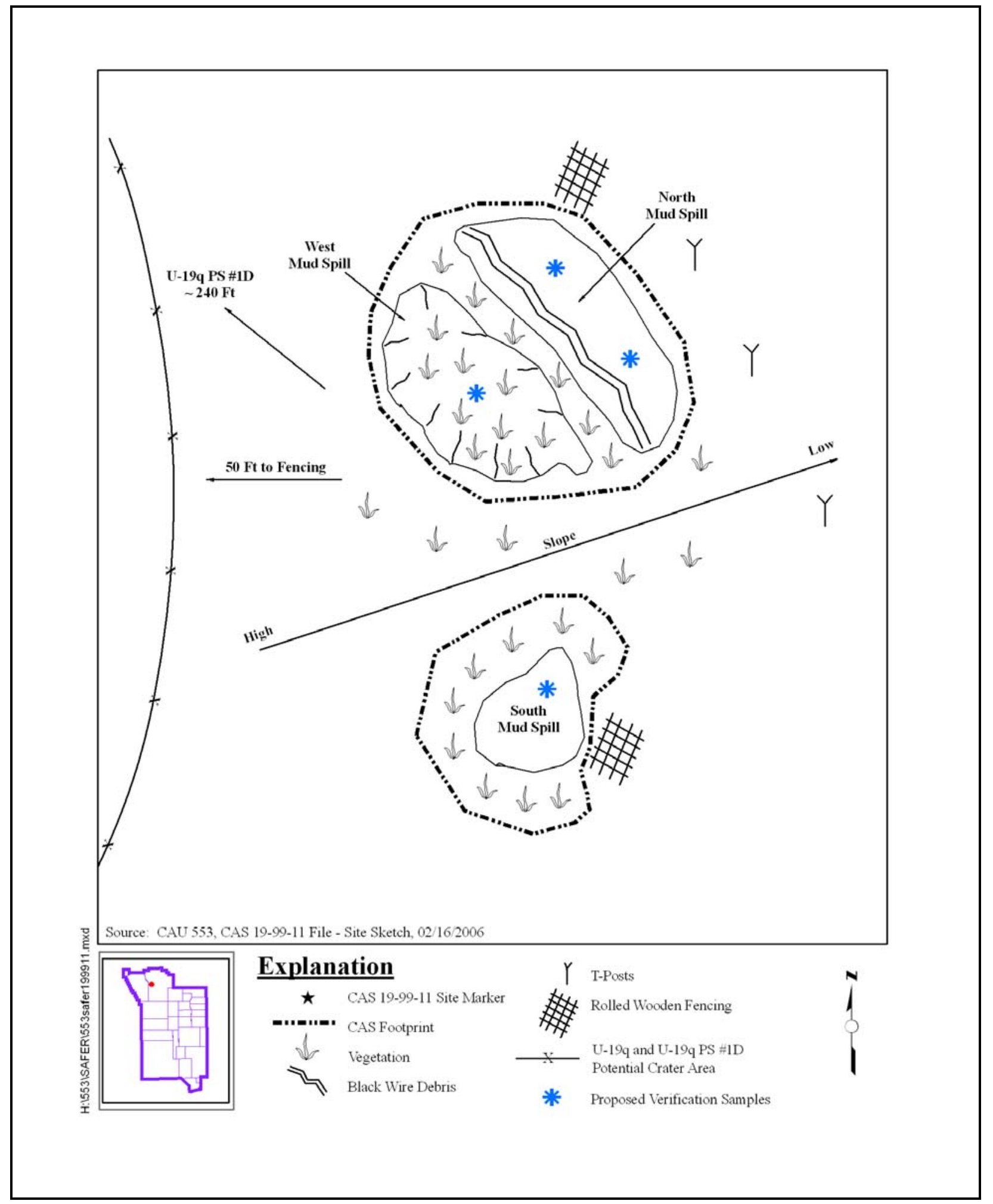

Figure B.9-2

Proposed Sample Locations CAS 19-99-11 


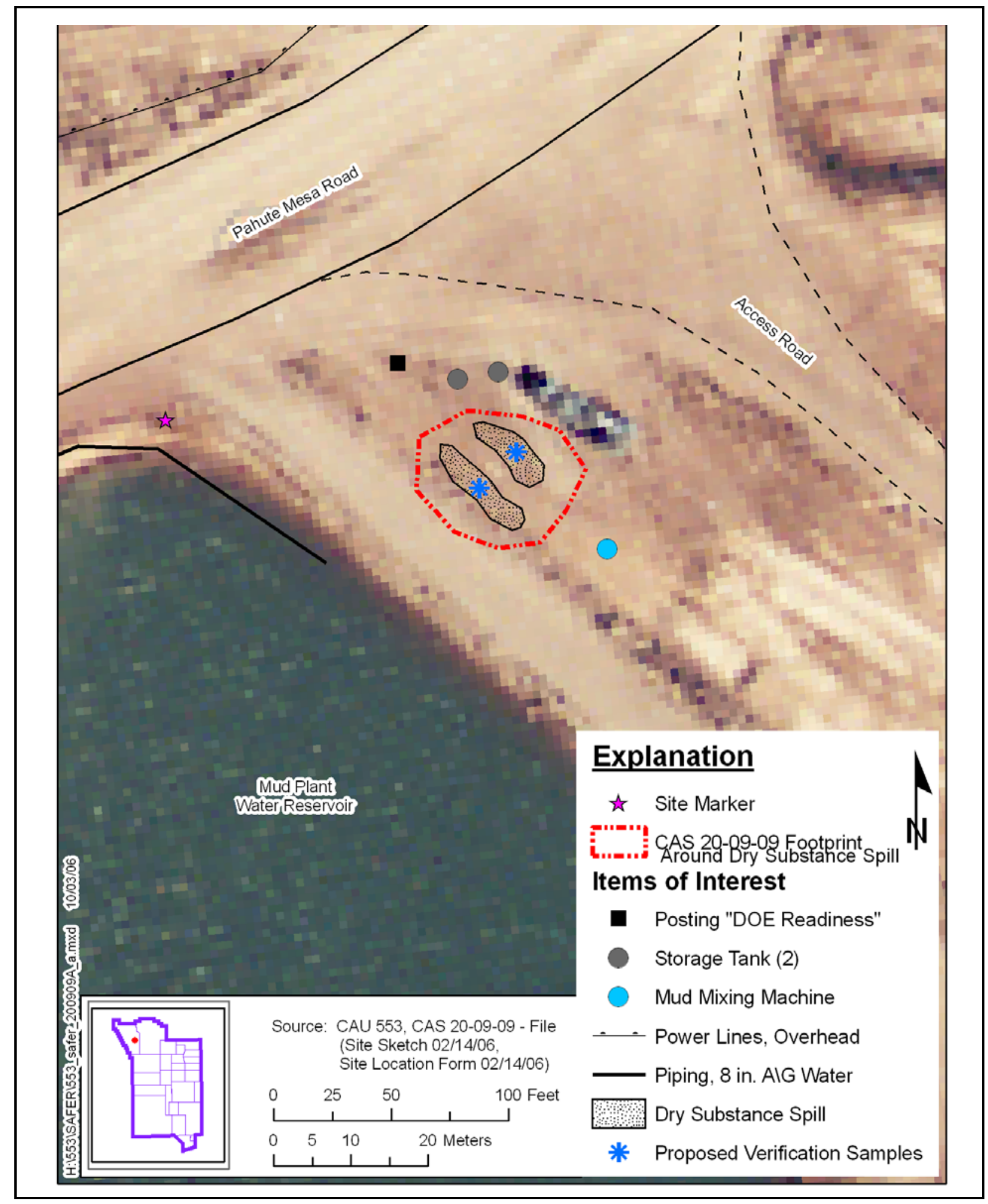

Figure B.9-3

Proposed Sample Locations CAS 20-09-09 
recommended with one from each quadrant of the spill area. See Figure B.9-4 for the proposed sample locations. Biasing factors will be identified during a site walkdown and the propose locations will be refined based on the site conditions. It is anticipated that most of the verification samples will be collected in pooled, concentrated areas of the mud due to the lack of apparent staining throughout the mud spill. 


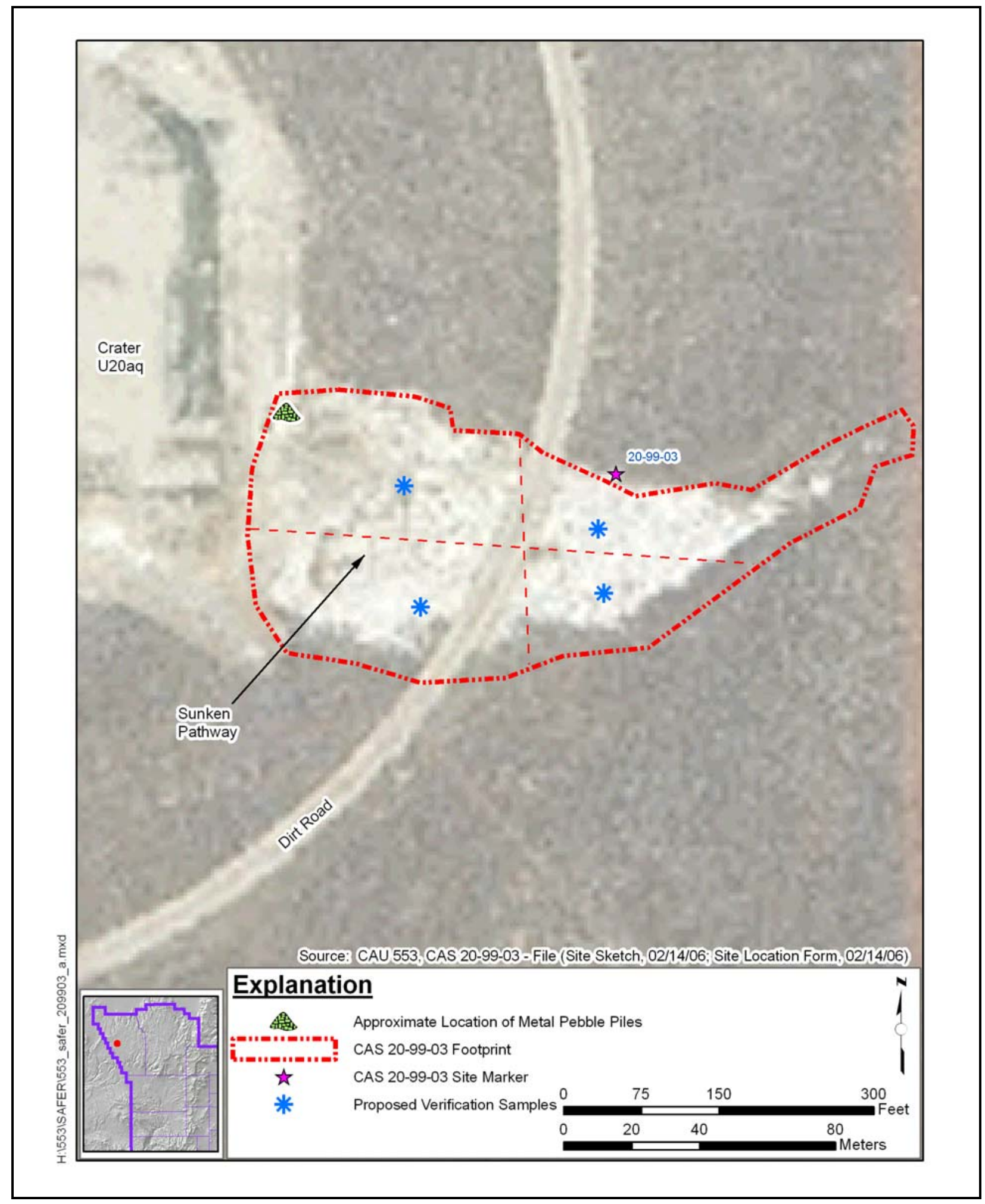

Figure B.9-4

Proposed Sample Locations CAS 20-99-03 


\section{B.10.0 References}

ASTM, see American Society for Testing and Materials.

Alderson, S., IT Corporation. 2002. Memorandum to R. Bull (SAIC) entitled, "Radiological Land Surveys of 24 Corrective Action Sites (CASs) at the Nevada Test Site.” 26 August.

Las Vegas, NV.

American Society for Testing and Materials. 1995. Standard Guide for Risk-Based Corrective Action Applied at Petroleum Release Sites/American Society for Testing and Materials, ASTM E1739-95 (Reapproved 2002). Philadelphia, PA.

DOE/NV, see U.S. Department of Energy, Nevada Operations Office.

EPA, see U.S. Environmental Protection Agency.

Fahringer, P., Stoller-Navarro Joint Venture. 2006. Memorandum to J. Myers (SNJV) entitled, “CAU 545, CAS 03-17-01 and CAU 553, CAS 19-99-01 - Memorandum of Findings,” April. Las Vegas, NV.

Geary, D. 1965. Letter to R.C. Emens (AEC) regarding the Pahute Mesa Mud Mixing Plant. 29 January. Las Vegas, NV.

IMANA, see Industrial Minerals Association - North America.

Industrial Minerals Association - North America. 2004. Bentonite. As accessed at www.ima-na.org/about_industrial_minerals/bentonite.asp on 3 February 2006. Calverton, MD.

Murphy, T., Bureau of Federal Facilities. 2004. Letter to R. Bangerter (NNSA/NSO) entitled, "Review of Industrial Sites Project Document Guidance for Calculating Industrial Sites Project Remediation Goals for Radionuclides in Soil Using the Residual Radiation (RESRAD) Computer Code." 19 November. Las Vegas, NV.

NAC, see Nevada Administrative Code.

NCRP, see National Council on Radiation Protection and Measurements.

NNSA/NV, see U.S. Department of Energy, National Nuclear Security Administration Nevada Operations Office.

NNSA/NSO, see U.S. Department of Energy, National Nuclear Security Administration Nevada Site Office. 
National Council on Radiation Protection and Measurements. 1999. Recommended Screening Limits for Contaminated Surface Soil and Review of Factors Relevant to Site-Specific Studies/National Council on Radiation Protection and Measurements, NCRP Report No. 129. Bethesda, MD.

Nevada Administrative Code. 2005. NAC 445A.2272, “Contamination of Soil: Establishment of Action Levels.” Carson City, NV.

RSN, see Raytheon Services Nevada.

REECo, see Reynolds Electrical \& Engineering Co., Inc.

Raytheon Services Nevada. 1991. Nevada Test Site Drilling \& Mining Summary. U.S. Department of Energy, Nevada Operations Office.

Reynolds Electrical \& Engineering Co., Inc. 1991. Nevada Test Site Inventory of Inactive and Abandoned Facilities and Waste Sites, Areas 16-20, Volume 4 of 5, DOE/NV 10630-18. April. Las Vegas, NV.

Reynolds Electrical \& Engineering Co., Inc. 1992. RCRA Part B Permit Application for Waste Management Activities at the Nevada Test Site: Section L, Potential Solid Waste Management Units. Nevada Test Site, NV.

Reynolds Electrical \& Engineering Co., Inc. 1994. Area 3 Waste Mud Impoundment - Historical Information. Prepared by C.G. Postle. Las Vegas, NV.

SNJV, see Stoller-Navarro Joint Venture.

Shaw, see Shaw Environmental, Inc.

Shaw Environmental, Inc. 2002. Results of Geophysical Survey Selected FFACO Sites Nevada Test Site, Nye County, Nevada, August. Las Vegas, NV.

Shott, G.J., V. Yucel, M.J. Sully, L.E. Barker, S.E. Rawlinson, and B.A. Moore. 1997. Performance Assessment/Composite Analysis for the Area 3 Radioactive Waste Management Site at the Nevada Test Site, Nye County, Nevada, Rev. 2.0. Las Vegas, NV.

Stoller-Navarro Joint Venture. 2006. Radiological Land Area Survey, CAU 553 - Areas 19, 20 Mud Pits and Cellars, at the Nevada Test Site. Las Vegas, NV.

USGS/DOE, see U.S. Geological Survey and U.S. Department of Energy.

U.S. Department of Energy. 1993. Radiation Protection of the Public and the Environment, DOE Order 5400.5, Change 2. Washington, DC: U.S. Government Printing Office. 
U.S. Department of Energy, National Nuclear Security Administration Nevada Operations Office. 2002. Industrial Sites Quality Assurance Project Plan, Nevada Test Site, Nevada, Rev. 3, DOE/NV-372. Las Vegas, NV.

U.S. Department of Energy, National Nuclear Security Administration Nevada Site Office. 2004a. Mud Pit Risk-Based Closure Strategy Report, Nevada Test Site, Nevada, DOE/NV—991. Las Vegas, NV.

U.S. Department of Energy, National Nuclear Security Administration Nevada Site Office. 2004b. Well U-19ad-PS 1A Preliminary Data Report Groundwater Characterization Sampling, Nevada Test Site, Nevada, November. Las Vegas, NV.

U.S. Department of Energy, National Nuclear Security Administration Nevada Site Office. 2006a. Closure Report for Corrective Action Units 530, 531, 532, 533, 534, 535: NTS Mud Pits, Nevada Test Site, Nevada, DOE/NV-1131. July. Las Vegas, NV.

U.S. Department of Energy, National Nuclear Security Administration Nevada Site Office. 2006b. Industrial Sites Project Establishment of Final Action Levels. February. Las Vegas, NV.

U.S. Department of Energy, Nevada Operations Office. 1992. Remedial Investigation and Feasibility Study for the Plutonium Contaminated Soils at Nevada Test Site, Nellis Air Force Range and Tonopah Test Range, April. Las Vegas, NV.

U.S. Department of Energy, Nevada Operations Office. 1996. Final Environmental Impact Statement for the Nevada Test Site and Off-Site Locations in the State of Nevada, DOE/EIS 0243. Las Vegas, NV.

U.S. Department of Energy, Nevada Operations Office. 1998a. Evaluation of Potential Hydrocarbon Transport at the UC-4 Emplacement Hole, Central Nevada Test Area, DOE/NV-11508-43. Prepared by B.F. Lyles, G. Pohll, D. Sloop, and C. Papelis. Las Vegas, NV.

U.S. Department of Energy, Nevada Operations Office. 1998b. Nevada Test Site Resource Management Plan, DOE/NV-518. Las Vegas, NV.

U.S. Department of Energy, Nevada Operations Office. 2000. United States Nuclear Tests, July 1945 Through September 1992, DOE/NV-209 (Rev. 15). Las Vegas, NV.

U.S. Department of Energy, Nevada Operations Office. 2001. Mud Pit Strategy, Nevada Test Site, Nevada, DOE/NV-684. Las Vegas, NV.

U.S. Environmental Protection Agency. 2002. Guidance for Quality Assurance Project Plans, EPA QA/G-5. Washington, DC. 
U.S. Environmental Protection Agency. 2004. Region 9 Preliminary Remediation Goals (PRGs). As accessed at http://www.epa.gov/region09/waste/sfund/prg/index.htm on 12 September 2006. Prepared by S.J. Smucker. San Francisco, CA.

U.S. Environmental Protection Agency. 2006. Guidance on Systematic Planning Using the Data Quality Objectives Process, EPA QA/G4. Washington, DC.

U.S. Geological Survey and U.S. Department of Energy. 2006a. "USGS/USDOE Cooperative Studies in Nevada Periodic Water Levels_-Nevada Test Site Map.” As accessed at http://nevada.usgs.gov/doe nv/ntsmap.htm on 4 March.

U.S. Geological Survey and U.S. Department of Energy. 2006b. “USGS/DOE” U-19bk WW” Web page. As accessed at http://nevada.usgs.gov/doe nv/ntsmap.htm on 4 March.

U.S. Geological Survey and U.S. Department of Energy. 2006c. “USGS/DOE” UE-19c WW” Web page. As accessed at http://nevada.usgs.gov/doe nv/ntsmap.htm on 4 March.

Winograd, I.J., and W. Thordarson. 1975. Hydrology and Hydrochemical Framework, South-Central Great Basin, Nevada-California, with Special Reference to the Nevada Test Site, USGS Professional Paper 712-C. Denver, CO. 


\section{Appendix C}

\section{Nevada Division of Environmental Protection Comments}




\section{C.1.0 Nevada Division of Environmental Protection Comments}

The Nevada Division of Environmental Protection has no comments at this time. Should NDEP submit comments at a later date, they will be included in Rev. 1 of this document. 


\section{Library Distribution List}

\begin{tabular}{|c|c|}
\hline & $\underline{\text { Copies }}$ \\
\hline $\begin{array}{l}\text { U.S. Department of Energy } \\
\text { National Nuclear Security Administration } \\
\text { Nevada Site Office } \\
\text { Technical Library } \\
\text { P.O. Box } 98518, \text { M/S } 505 \\
\text { Las Vegas, NV 89193-8518 }\end{array}$ & 1 (Uncontrolled) \\
\hline $\begin{array}{l}\text { U.S. Department of Energy } \\
\text { Office of Scientific and Technical Information } \\
\text { P.O. Box } 62 \\
\text { Oak Ridge, TN 37831-0062 }\end{array}$ & 1 (Uncontrolled, electronic copy) \\
\hline $\begin{array}{l}\text { Southern Nevada Public Reading Facility } \\
\text { c/o Nuclear Testing Archive } \\
\text { P.O. Box 98521, M/S } 400 \\
\text { Las Vegas, NV 89193-8521 }\end{array}$ & 2 (Uncontrolled, electronic copy) \\
\hline $\begin{array}{l}\text { Manager, Northern Nevada FFACO } \\
\text { Public Reading Facility } \\
\text { c/o Nevada State Library \& Archives } \\
\text { Carson City, NV 89701-4285 }\end{array}$ & 1 (Uncontrolled, electronic copy) \\
\hline
\end{tabular}

